\title{
(ब्)
}

AUTARQUIA ASSOCIADA À UNIVERSIDADE DE SÃO PAULO

\section{EFEITO DE TRATAMENTOS TÉRMICOS EM INSERTOS DE ASSENTOS DE VÁLVULAS SINTERIZADOS}

\section{MAURILIO PEREIRA GOMES}

Dissertação apresentada como parte dos requisitos para obtenção do Grau de Mestre em Ciências na Área de Tecnologia Nuclear - Materiais

Orientador:

Prof. Dr. Jesualdo Luiz Rossi 
INSTITUTO DE PESQUISAS ENERGÉTICAS E NUCLEARES

Autarquia associada à Universidade de São Paulo

EFEITO DE TRATAMENTOS TÉRMICOS EM INSERTOS DE ASSENTOS DE VÁLVULAS SINTERIZADOS

MAURILIO PEREIRA GOMES

Dissertação apresentada como parte dos requisitos para obtenção do Grau de Mestre em Ciências na Área de Tecnologia Nuclear - Materiais

Orientador:

Prof. Dr. Jesualdo Luiz Rossi

Versão Corrigida

Versão Original disponível no IPEN

São Paulo

2017 


\section{AGRADECIMENTOS}

Ao meu orientador, Prof. Dr. Jesualdo Luiz, por compartilhar seu conhecimento técnico e científico, que muito contribuiu em cada etapa deste trabalho. Não posso deixar de mencionar minha imensa gratidão pela amizade, companheirismo, confiança, auxílios dos mais diversos tipos e, cada ensinamento ao longo desta jornada. Sempre serei agradecido.

À Dra. Lusinete Pereira Barbosa, pelas diversas contribuições e discussões que se deram durante nossos encontros vespertinos em sua sala. Mais do que uma companheira de trabalho, uma eterna amizade que levarei comigo.

Ao Prof. Dr. Cristiano Stefano Mucsi, sendo mais do que um ombro amigo em diversos momentos. Meus agradecimentos pelas várias conversas que tivemos, tornando possível uma expansão da minha visão em relação a este mundo que nos cerca. Tal contribuição tornou possível o meu desenvolvimento pleno como cidadão e aluno.

À minha amada família, que apesar da minha ausência sempre procurou me ajudar de todas as maneiras possíveis. Em especial aos meus pais, José e Florinda, e, aos meus irmãos Henrique, Isaias e Otavio, pois grande parte dos meus esforços são para servir de exemplo a eles e, mostrar que nada é impossível, basta acreditarmos. E também a Luciana Fernandes que recentemente entrou na minha vida.

Não posso deixar de mencionar as diversas amizades que frutificaram ao longo deste caminho trilhado, amizades estas que estarão comigo para sempre. Em nome de Luís Augusto, que é mais que um irmão para mim, Maicon, Giuseppe, Marcelo de Oliveira, Caio Palumbo, Francisco, Camila, Eduardo Nogueira, Larissa, Bárbara, Donatus, Daniela Leite, Paulo Costinhas, Fátima, Geraldo, entre outros.

Também quero deixar meu profundo agradecimento à Profa. Dra. Isolda Costa, ao Prof. Dr. Rodolfo Politano, Prof. Dr. Luís Gallego Martinez, Prof. Dr. Xabier Turrilas, Prof. Dr. Hidetoshi Takiishi e Marcelo Alves de Oliveira.

À Coordenação de Aperfeiçoamento de Pessoal de Nível Superior CAPES, pelo financiamento da bolsa de mestrado.

Ao Instituto de Pesquisas Energéticas e Nucleares - IPEN, por conceder espaço, materiais, recursos os mais diversos e conhecimento científico. 
"Só o conhecimento da verdade torna os homens livres. As distintas seitas parecem rivalizar em ignorância. É inútil mudar de pasto: o essencial é deixar de ser boi!"

Jorge Ángel Livraga Rizzi (1930-1991)

Escritor

"O homem tem o tamanho daquilo que se atreve a fazer."

Jorge Ángel Livraga Rizzi (1930-1991)

Escritor 


\title{
EFEITO DE TRATAMENTOS TÉRMICOS EM INSERTOS DE ASSENTOS DE VÁLVULAS SINTERIZADOS
}

\author{
Maurilio Pereira Gomes
}

\section{RESUMO}

Atualmente, uns dos grandes desafios para a indústria automobilística é aumentar o desempenho do conjunto mecânico responsável por selar a câmara de combustão interna de motores automotivos e também reduzir os seus custos de obtenção. O objetivo deste trabalho foi 0 de tratar termicamente insertos de assentos de válvulas (do inglês valve seat insert, VSI) obtidos pela rota de metalurgia do pó. Esta técnica possibilitou a substituição do cobalto e do chumbo, devido ao seu elevado custo e efeito toxicológico, respectivamente. Ao longo do trabalho foram avaliados $V S I$ obtidos com três misturas de pós diferentes, sendo que os elementos comuns nestas três misturas foram os pós de ferro, sulfeto de manganês, carboneto de nióbio, grafite, estearato de zinco e cobre. Em cada uma destas misturas variou-se apenas os tipos de pós de aços rápidos e aço ferramenta utilizado, sendo estes o aço rápido AISI M3:2 (Mistura 1), aço rápido AISI M2 (Mistura 2) e aço ferramenta AISI D2 (Mistura 3). Os tratamentos térmicos aplicados aos $\mathrm{VSI}$ consistiram em têmpera ao ar e têmpera ao óleo, ambas seguidas de duplo revenimento em sete temperaturas equidistantemente diferentes, variando de 100 ${ }^{\circ} \mathrm{C}$ a $700{ }^{\circ} \mathrm{C}$. Os ciclos dos tratamentos térmicos foram determinados por meio da utilização de termopares do tipo $\mathrm{k}$ acoplados à um sistema de aquisição de dados. As propriedades físicas e mecânicas dos VSI foram determinadas através da dureza aparente, densidade aparente e resistência à ruptura radial. A caracterização microestrutural foi realizada utilizando-se a microscopia óptica e microscopia eletrônica de varredura. A composição química foi determinada por meio da análise elementar e por espectrometria de fluorescência de energia dispersiva de raios $X$. Os melhores resultados em relação às propriedades mecânicas dos $\mathrm{VSI}$ foram obtidas para os insertos temperados ao ar e duplamente revenido a $600^{\circ} \mathrm{C}$ para a Mistura 1 e Mistura 2, e a $500^{\circ} \mathrm{C}$ para Mistura 3. Já para a têmpera ao óleo, as melhores respostas foram para os $\mathrm{VSI}$ obtidos com a Mistura 1 duplamente revenida a $400{ }^{\circ} \mathrm{C}$ e a, $300^{\circ} \mathrm{C}$ para os componentes obtidos com a Mistura 2 e Mistura 3.

Palavras-chave: metalurgia do pó, tratamento térmico, aço rápido, aço ferramenta, inserto de assento de válvula. 


\title{
EFFECT OF HEAT TREATMENTS ON SINTERED VALVE SEAT INSERTS
}

\author{
Maurilio Pereira Gomes
}

\begin{abstract}
Currently, one of the biggest challenges for the automobile industry is to increase the performance of the mechanical set responsible for sealing the internal combustion chamber in automotive engines and reduce its cost of production. The aim of the present work was to heat treat valve seat inserts (VSI) obtained through the powder metallurgy route. This procedure made possible the substitution of cobalt and lead, due to its high cost and toxicological effect, respectively. Throughout the work, it was evaluated VSI obtained with three different types of powders mixtures, and common elements at the three different powders mixtures were iron powder, manganese sulfide, niobium carbide, graphite, zinc stearate and copper. In each of these powders mixtures, it was changed only the type of highspeed steels and tool steel, consisting of high-speed steel AISI M3:2 (Mixture 1), high-speed steel AISI M2 (Mixture 2) and tool steel AISI D2 (Mixture 3). The heat treatments applied to the VSI were air quenching and oil quenching, both followed by double tempering at seven different equidistantly temperatures, ranging from 100 ${ }^{\circ} \mathrm{C}$ up to $700{ }^{\circ} \mathrm{C}$. The heat treatments thermal cycles were determined using a thermocouple type $k$ attached to a data acquisition system. The physical and mechanical properties of the VSI were measured in terms of apparent hardness, apparent density and crush radial strength. Microstructural characterization was performed using optical and scanning electron microscopy. The chemical composition was determined using gas analysis and energy dispersive X-ray fluorescence spectrometry. The best results regarding the mechanical properties of the VSI were obtained for the VSI air-quenched and double tempered at $600{ }^{\circ} \mathrm{C}$ for the powder Mixture 1 and Mixture 2, and at $500{ }^{\circ} \mathrm{C}$ for Mixture 3. For the oil quenching, the best response was reached for the VSI obtained with Mixture 1 double tempered at $400{ }^{\circ} \mathrm{C}$, and at $300^{\circ} \mathrm{C}$ for the components obtained with Mixture 2 and Mixture 3.
\end{abstract}

Keywords: powder metallurgy, heat treatment, high-speed steel, tool steel, valve seat insert. 
Página

AGRADECIMENTOS.

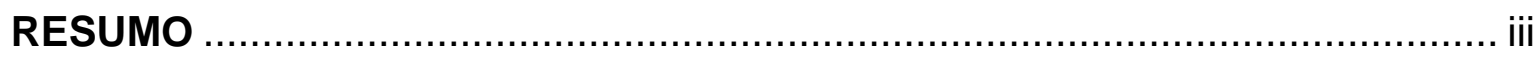

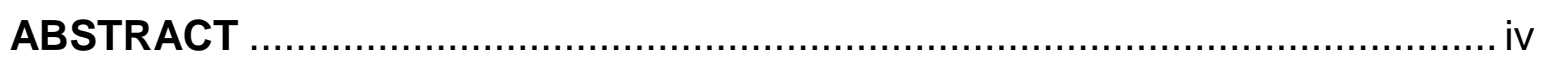

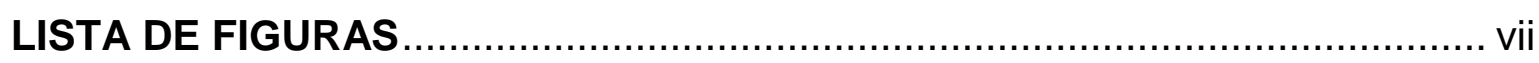

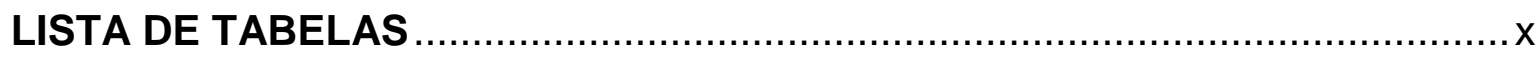

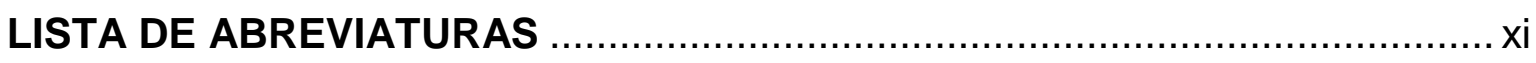

1 INTRODUÇÃO

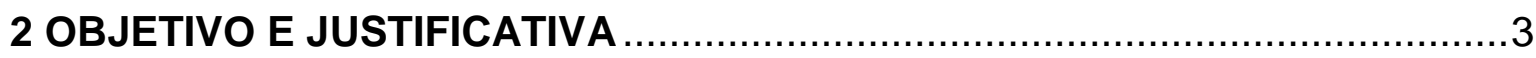

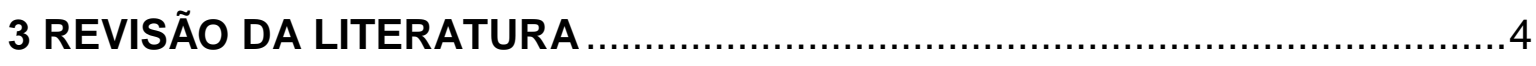

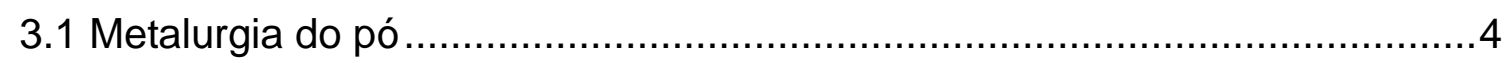

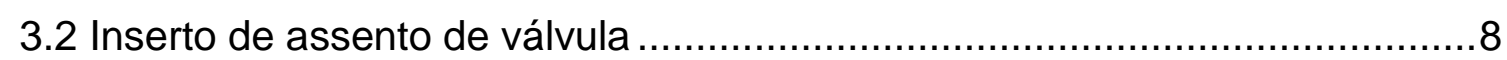

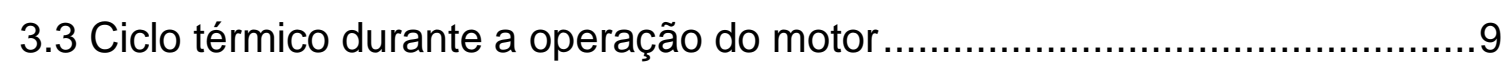

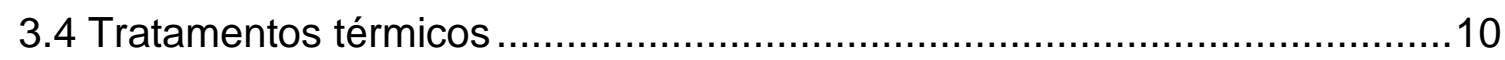

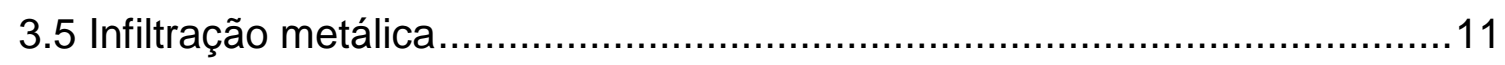

4 MATERIAIS E MÉTODOS .................................................................. 13

4.1 Obtenção dos insertos de assentos de válvulas.........................................13

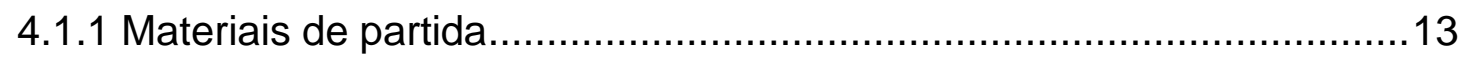

4.1.2 Caracterização dos pós .............................................................. 14

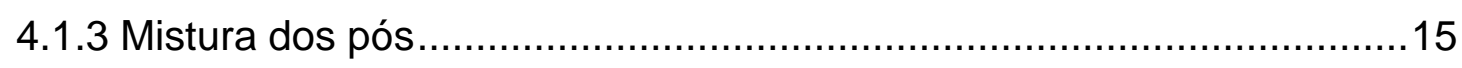

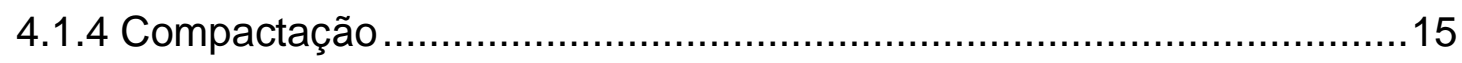

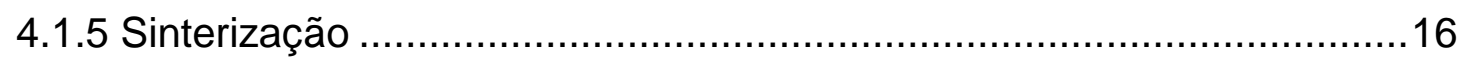

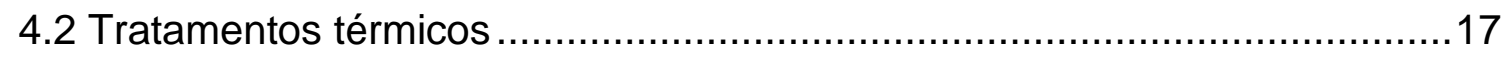

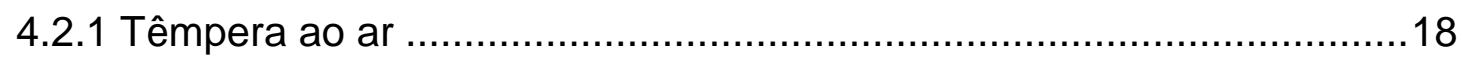

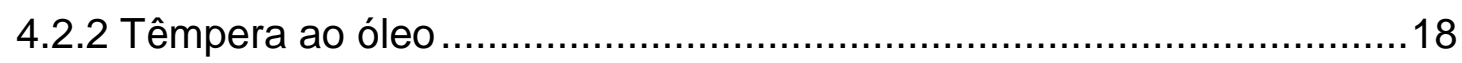

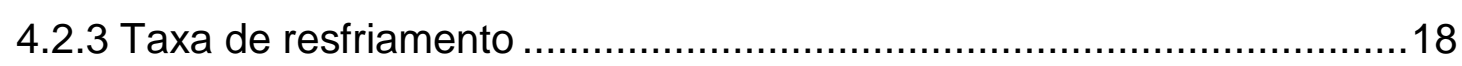

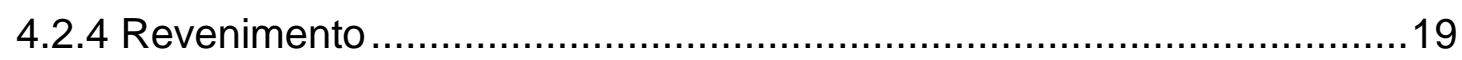

4.3 Caracterização dos insertos de assentos de válvulas ...............................19

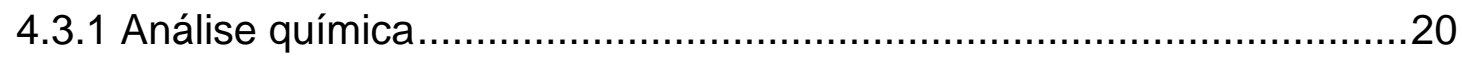

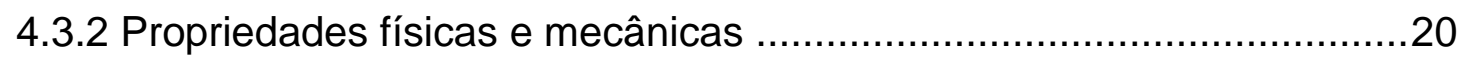

4.3.3 Caracterização microestrutural .....................................................22 


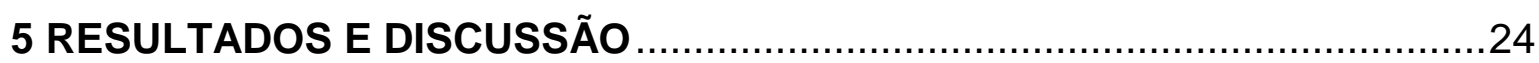

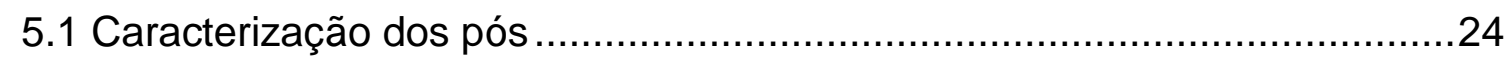

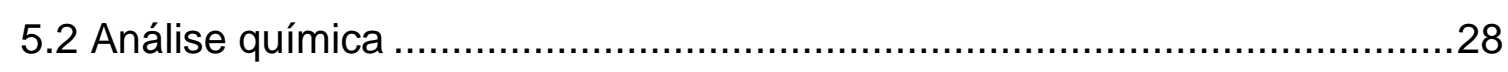

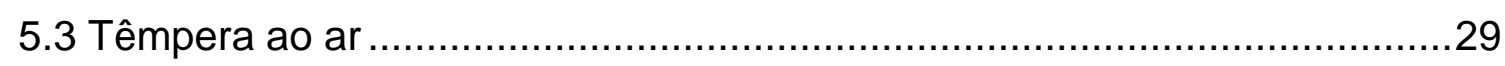

5.3.1 Propriedades físicas e mecânicas …………...................................29

5.3.2 Diagramas de transformação de fase ................................................

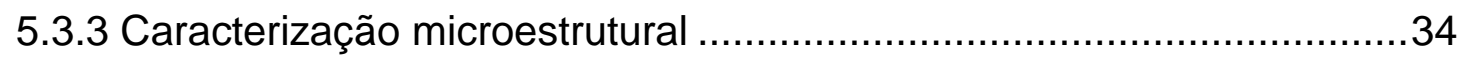

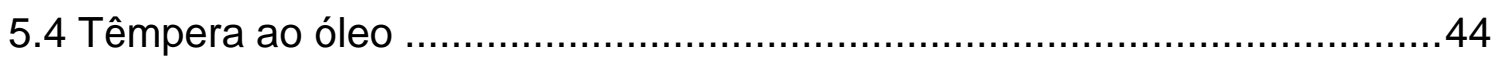

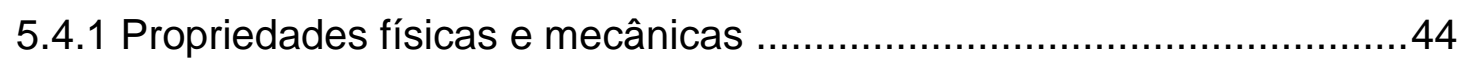

5.4.2 Diagramas de transformação de fase .............................................4 47

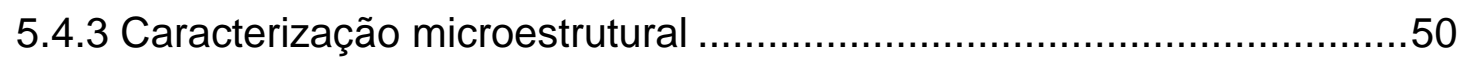

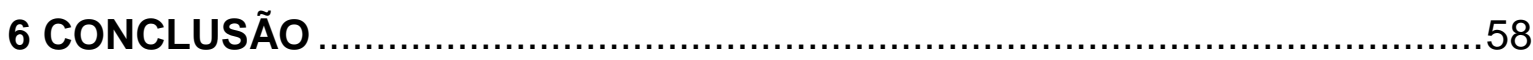

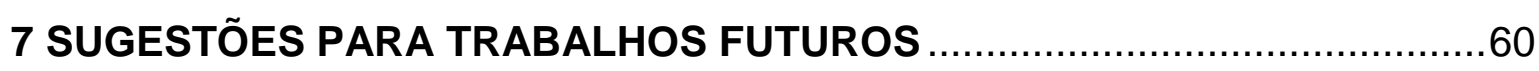

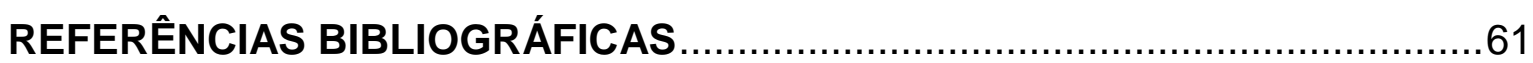




\section{LISTA DE FIGURAS}

Página

FIGURA 3.1 - Comparação entre o consumo de material e energia necessária para produzir-se $1 \mathrm{~kg}$ de produto acabado por meio de diferentes processos produtivos (Zapata, 1987; Thümmler e Oberacker, 1993).

FIGURA 3.2 - Representação esquemática das várias etapas do processo de metalurgia do pó, adaptado de Chiaverini (1992). 7

FIGURA 3.3 - Desenho esquemático indicando a distribuição espacial da válvula e do VSI em um motor de combustão interna.

FIGURA 3.4 - Esboço da sequência de infiltração metálica, onde as forças capilares impulsionam o metal fundido para dentro dos poros abertos de um compactado poroso, adaptado de German (2005). 12

FIGURA 4.1 - VSI compactados a verdes obtidos após a prensagem das diferentes misturas de pós a pressão de $700 \mathrm{MPa}$. 15

FIGURA 4.2 - Anéis de cobre compactados a verdes obtidos após a prensagem do pó de cobre a pressão de $700 \mathrm{MPa}$.

FIGURA 4.3 - Montagem do anel de cobre e VSI compactados a verde para a execução da etapa de infiltração metálica precedendo a etapa de sinterização. .17

FIGURA 4.4 - Fluxograma dos métodos e sequência adotada para a caracterização dos VSI. 20

FIGURA 5.1 - Variação da dureza Brinell (HB 2,5 / 187,5) nos VSI apenas como sinterizados e também nos componentes temperados ao ar e duplamente revenido em sete temperaturas diferentes.

FIGURA 5.2 - Diagrama de transformação isotérmica (T.T.T.) para o aço rápido AISI M3:2 (Metal Ravne, 2016). 32

FIGURA 5.3 - Diagrama de transformação sob resfriamento contínuo (C.C.T.) para o aço rápido AISI M2 (Vander Voort, 1991). 33

FIGURA 5.4 - Diagrama de transformação sob resfriamento contínuo (C.C.T.) para o aço rápido AISI D2 (Vander Voort, 1991).

FIGURA 5.5 - llustração de onde os VSI foram seccionados para a avaliação da sua seção transversal e longitudinal. 35

FIGURA 5.6 - Micrografia óptica da seção transversal do VSI obtido com a Mistura 1 (AISI M3:2) temperado ao ar e duplamente revenido a $600^{\circ} \mathrm{C}$. Ataque: Nital $3 \%$ por $5 \mathrm{~s}$.

FIGURA 5.7 - Micrografia óptica da seção longitudinal do VSI obtido com a Mistura 1 (AISI M3:2) temperado ao ar e duplamente revenido a $600{ }^{\circ} \mathrm{C}$. Ataque: Nital $3 \%$ por $5 \mathrm{~s}$. 
FIGURA 5.8 - Micrografia óptica da seção transversal do VSI obtido com a Mistura 2 (AISI M2) temperado ao ar e duplamente revenido a $600^{\circ} \mathrm{C}$. Ataque: Nital $3 \%$ por $5 \mathrm{~s}$. 37

FIGURA 5.9 - Micrografia óptica da seção longitudinal do VSI obtido com a Mistura 2 (AISI M2) temperado ao ar e duplamente revenido a $600^{\circ} \mathrm{C}$. Ataque: Nital $3 \%$ por $5 \mathrm{~s}$. .38

FIGURA 5.10 - Micrografia óptica da seção transversal do VSI obtido com a Mistura 3 (AISI D2) temperado ao ar e duplamente revenido a $500^{\circ} \mathrm{C}$. Ataque: Nital $3 \%$ por $5 \mathrm{~s}$. 39

FIGURA 5.11 - Micrografia óptica da seção longitudinal do VSI obtido com a Mistura 3 (AISI D2) temperado ao ar e duplamente revenido a $500^{\circ} \mathrm{C}$. Ataque: Nital $3 \%$ por $5 \mathrm{~s}$.

FIGURA 5.12 - Micrografia obtida por MEV com identificação de elementos por EDS da seção transversal do VSI obtido com a Mistura 1, após temperado ao ar e duplamente revenido a $600{ }^{\circ} \mathrm{C}$. Ataque: Nital $3 \%$ por $50 \mathrm{~s}$.

FIGURA 5.13 - Micrografia obtida por MEV com identificação de elementos por EDS da seção longitudinal do VSI obtido com a Mistura 1, após temperado ao ar e duplamente revenido a $600{ }^{\circ} \mathrm{C}$. Ataque: Nital $3 \%$ por $50 \mathrm{~s}$.

FIGURA 5.14 - Micrografia obtida por MEV com identificação de elementos por EDS da seção transversal do VSI obtido com a Mistura 2, após temperado ao ar e duplamente revenido a $600^{\circ} \mathrm{C}$. Ataque: Nital $3 \%$ por $50 \mathrm{~s}$.

FIGURA 5.15 - Micrografia obtida por MEV com identificação de elementos por EDS da seção longitudinal do VSI obtido com a Mistura 2, após temperado ao ar e duplamente revenido a $600^{\circ} \mathrm{C}$. Ataque: Nital $3 \%$ por $50 \mathrm{~s}$. 42

FIGURA 5.16 - Micrografia obtida por MEV com identificação de elementos por EDS da seção transversal do VSI obtido com a Mistura 3, após tempera ao ar e revenido duplo a $500{ }^{\circ} \mathrm{C}$. Ataque: Nital $3 \%$ por $50 \mathrm{~s}$. .43

FIGURA 5.17 - Micrografia obtida por MEV com identificação de elementos por EDS da seção longitudinal do VSI obtido com a Mistura 3, após tempera ao ar e revenido duplo a $500{ }^{\circ} \mathrm{C}$. Ataque: Nital $3 \%$ por $50 \mathrm{~s}$.

FIGURA 5.18 - Variação da dureza Brinell (HB 2,5 / 187,5) nos VSI apenas como sinterizados e também nos componentes temperados ao óleo e duplamente revenido em sete temperaturas diferentes.

FIGURA 5.19 - Diagrama de transformação isotérmica (T.T.T.) para o aço rápido AISI M3:2 (Metal Ravne, 2016).

FIGURA 5.20 - Diagrama de transformação sob resfriamento contínuo (C.C.T.) para o aço rápido AISI M2 (Vander Voort, 1991).

FIGURA 5.21 - Diagrama de transformação sob resfriamento contínuo (C.C.T.) para o aço rápido AISI D2 (Vander Voort, 1991). 
FIGURA 5.22 - Micrografia óptica da seção transversal do VSI obtido com a Mistura 1 (AISI M3:2) temperado ao óleo e duplamente revenido a $400{ }^{\circ} \mathrm{C}$. Ataque: Nital $3 \%$ por $5 \mathrm{~s}$. .50

FIGURA 5.23 - Micrografia óptica da seção longitudinal do VSI obtido com a Mistura 1 (AISI M3:2) temperado ao óleo e duplamente revenido a $400{ }^{\circ} \mathrm{C}$. Ataque: Nital $3 \%$ por $5 \mathrm{~s}$. .51

FIGURA 5.24 - Micrografia óptica da seção transversal do VSI obtido com a Mistura 2 (AISI M2) temperado ao óleo e duplamente revenido a $300^{\circ} \mathrm{C}$. Ataque: Nital $3 \%$ por $5 \mathrm{~s}$. .52

FIGURA 5.25 - Micrografia óptica da seção longitudinal do VS/ obtido com a Mistura 2 (AISI M2) temperado ao óleo e duplamente revenido a $300{ }^{\circ} \mathrm{C}$. Ataque: Nital $3 \%$ por $5 \mathrm{~s}$.

FIGURA 5.26 - Micrografia óptica da seção transversal do VSI obtido com a Mistura 3 (AISI D2) temperado ao óleo e duplamente revenido a $300^{\circ} \mathrm{C}$. Ataque: Nital $3 \%$ por $5 \mathrm{~s}$.

FIGURA 5.27 - Micrografia óptica da seção longitudinal do VS/ obtido com a Mistura 3 (AISI D2) temperado ao óleo e duplamente revenido a $300{ }^{\circ} \mathrm{C}$. Ataque: Nital $3 \%$ por $5 \mathrm{~s}$. .53

FIGURA 5.28 - Micrografia obtida por MEV com identificação de elementos por EDS da seção transversal do $\mathrm{VSI}$ obtido com a Mistura 1, após temperado ao óleo e duplamente revenido a $400^{\circ} \mathrm{C}$. Ataque: Nital $3 \%$ por $50 \mathrm{~s}$. .54

FIGURA 5.29 - Micrografia obtida por MEV com identificação de elementos por EDS da seção longitudinal do VSI obtido com a Mistura 1, após temperado ao óleo e duplamente revenido a $400{ }^{\circ} \mathrm{C}$. Ataque: Nital $3 \%$ por $50 \mathrm{~s}$. .55

FIGURA 5.30 - Micrografia obtida por MEV com identificação de elementos por EDS da seção transversal do $\mathrm{VSI}$ obtido com a Mistura 2, após temperado ao óleo e duplamente revenido a $300{ }^{\circ} \mathrm{C}$. Ataque: Nital $3 \%$ por $50 \mathrm{~s}$. .55

FIGURA 5.31 - Micrografia obtida por MEV com identificação de elementos por EDS da seção longitudinal do VSI obtido com a Mistura 2, após temperado ao óleo e duplamente revenido a $300^{\circ} \mathrm{C}$. Ataque: Nital $3 \%$ por $50 \mathrm{~s}$.

FIGURA 5.32 - Micrografia obtida por MEV com identificação de elementos por EDS da seção transversal do $\mathrm{VSI}$ obtido com a Mistura 3, após temperado ao óleo e duplamente revenido a $300^{\circ} \mathrm{C}$. Ataque: Nital $3 \%$ por $50 \mathrm{~s}$.

FIGURA 5.33 - Micrografia obtida por MEV com identificação de elementos por EDS da seção longitudinal do VSI obtido com a Mistura 3, após temperado ao óleo e duplamente revenido a $300{ }^{\circ} \mathrm{C}$. Ataque: Nital $3 \%$ por $50 \mathrm{~s}$. 


\section{LISTA DE TABELAS}

Página

TABELA 4.1 - Composição nominal (\% massa) das três misturas de pós. 14

TABELA 4.2 - Composição química nominal (\% massa) dos pós de aço rápido e aço ferramenta (Totten, 2006)

TABELA 5.1 - Gráficos das distribuições dos tamanhos de partículas obtidos por difração a laser dos seguintes pós: $(A A)$ aço rápido $A I S I M 3: 2,(A B)$ aço rápido AISI M2, (BA) aço ferramenta AISI D2, (BB) ferro, (CA) sulfeto de manganês, (CB) carboneto de nióbio, (DA) grafite e (DB) cobre. 25

TABELA 5.2 - Compilação dos dados da distribuição do tamanho de partícula dos diferentes pós utilizados obtidos por difração a laser

TABELA 5.3 - Micrografia obtida por MEV mostrando a morfologia dos seguintes pós: $(A A)$ aço rápido AISI M3:2, (AB) aço rápido AISI M2, (BA) aço ferramenta AISI $\mathrm{D} 2,(\mathrm{BB})$ ferro, $(\mathrm{CA})$ sulfeto de manganês, $(\mathrm{CB})$ carboneto de nióbio e (DA) grafite.

TABELA 5.4 - Composição química (\% massa), obtida por análise elementar e por EDXRFS, dos VSI obtidos com três misturas de pós diferentes. Os teores de carbono e enxofre foram determinados usando a técnica de análise elementar e os outros elementos foram determinados por EDXRFS.

TABELA 5.5 - Variação da dureza Brinell (HB 2,5 / 187,5) nos VSI apenas como sinterizados e também nos componentes temperados ao ar e duplamente revenido em sete temperaturas diferentes 30

TABELA 5.6 - Principais propriedades físicas e mecânicas dos VSI obtidos com a Mistura 1 (AISI M3:2), Mistura 2 (AISI M2) e Mistura 3 (AISI D2), temperados ao ar e duplamente revenido a $600^{\circ} \mathrm{C}, 600^{\circ} \mathrm{C}$ e $500^{\circ} \mathrm{C}$, respectivamente. 31

TABELA 5.7 - Variação da dureza Brinell (HB 2,5 / 187,5) nos VSI apenas como sinterizado e também nos componentes temperados ao óleo e duplamente revenido em sete temperaturas diferentes 45

TABELA 5.8 - Principais propriedades físicas e mecânicas dos VS/ obtidos com a Mistura 1 (AISI M3:2), Mistura 2 (AISI M2) e Mistura 3 (AISI D2), temperados ao óleo e duplamente revenido a $400^{\circ} \mathrm{C}, 300^{\circ} \mathrm{C}$ e $300^{\circ} \mathrm{C}$, respectivamente. 


\section{LISTA DE ABREVIATURAS}

BSE Elétrons retroespalhados, do inglês backscattered electrons

C.C.T. Transformação sob resfriamento contínuo, do inglês continous cooling transformation

EDS Espectroscopia por energia dispersiva, do inglês energy dispersive spectroscopy

EDXRFS Espectrometria por energia dispersiva de fluorescência de raios $X$, do inglês energy dispersive $X$-ray fluorescence spectrometry

Et al. E outros, do latim et alii

I.E. Isto é, do latim id est

MEV Microscopia eletrônica de varredura

MO Microscopia óptica

Nihil Nada, do latim Nihil

T.T.T. Tempo-temperatura-transformação, do inglês time-temperaturetransformation

VSI Inserto de assento de válvula, do inglês valve seat insert 


\section{INTRODUÇÃo}

No começo do século XX, os veículos movidos a gasolina dividiam o mercado com outras formas de propulsão, tais como veículos movidos a vapor e a eletricidade. O carro movido a vapor, resultante da queima do carvão, era mais pesado, pois exigia espaço para o armazenamento de água e um compartimento para fervê-la. Já o carro elétrico possuía um projeto inferior, pois imitava as carroças da época e apresentava problemas com o carregamento das baterias (Høyer, 2008). Então os veículos movidos a gasolina, mais elegantes e com maior autonomia, conquistaram o mercado (Andress et al., 2012).

A preocupação em atender as políticas ambientais e ao mesmo tempo reduzir o custo de produção pressiona as tecnologias e soluções tradicionais em vários segmentos (Midler e Beaume, 2010). O motor a combustão interna é das tecnologias estabelecidas a mais duradoura, sendo desafiado por uma emergente onda de novas tecnologias (Hekkert, 2004). Os motores automotivos têm passado por mudanças substanciais e constantes, que resultam em elevado desempenho, redução do consumo de combustível e impacto ambiental (Chang e Zhao, 2013).

Parte do conjunto mecânico responsável por selar a câmara de combustão é constituído pelo assento da válvula e o inserto de assento de válvula. O desenvolvimento atual destes componentes se apresenta como um grande desafio quando o objetivo é aumentar o seu desempenho, e reduzir o custo para sua obtenção (Jesus Filho, 2006). Os VSI operam sob condições severas, sendo submetidos à um meio caracterizado por altas tensões mecânicas, quimicamente agressivo, altas temperaturas, desgaste, erosão e corrosão (Salgado et al., 2001).

O presente estudo foi realizado como sequência a dois trabalhos previamente desenvolvidos na mesma instituição de ensino, sendo ambos intrinsecamente relacionados aos VSI. O primeiro trabalho culminou na tese de doutorado do Edson de Jesus Filho (Jesus Filho, 2006), em que foi proposto o desenvolvimento de $\mathrm{VS} /$ sinterizados com novas misturas de pós, sendo esta uma alternativa às técnicas de obtenção de tal componente até então, objetivando a substituição do cobalto e do chumbo. Após diversos estudos, os componentes 
obtidos com a mistura de pós contendo o aço rápido AISI M3:2 mostraram os melhores resultados. Esta mistura de pós, por sua vez, resultou em uma patente para a obtenção de VSI com tal composição química (CNEN, 2006).

O segundo trabalho resultou na dissertação de mestrado de Igor Passos dos Santos (Santos, 2014), onde foi feito um estudo referente a obtenção de VSI com outras misturas de pós diferentes. Em suma, além de considerar a mistura de pós (aço rápido AISI M3:2) do trabalho do Jesus Filho (2006), foi proposta a obtenção de VSI com mais dois tipos de misturas de pós, contendo como elementos principais o aço rápido AISI M2 e o aço ferramenta AISI D2. 


\section{OBJETIVO E JUSTIFICATIVA}

O objetivo do presente trabalho foi o de investigar os efeitos dos tratamentos térmicos de têmpera ao ar e têmpera ao óleo, ambas seguidas de duplo revenimento em sete temperaturas equidistantemente diferentes, variando de $100^{\circ} \mathrm{C}$ a $700{ }^{\circ} \mathrm{C}$ em insertos de assentos de válvula sinterizados.

A justificativa se deu pela investigação da influência dos tratamentos térmicos quanto a variação microestrutural e das propriedades físicas e mecânicas dos insertos de assentos de válvulas sinterizados, já que os diferentes tratamentos térmicos aplicados resultaram na melhoria das propriedades físicas e mecânicas dos insertos. 


\section{REVISÃO DA LITERATURA}

$\mathrm{Na}$ revisão da literatura realizou-se o apanhado histórico da evolução dos insertos de assentos de válvulas. Com isto, mostrou-se quais condições de operações estes componentes são submetidos e quais são as etapas que se seguem durante sua obtenção, sendo enfatizadas algumas destas, como por exemplo o processo de infiltração metálica. Por fim, detalhou-se a influência dos tratamentos térmicos em corpos sinterizados.

\subsection{Metalurgia do pó}

A técnica de metalurgia do pó foi praticada muito tempo antes dos artesãos antigos aprenderem a fundir os aços. A primeira metalurgia do ferro que se tem notícia data de 6.000 a.C., quando foram obtidos a baixas temperaturas em um forno primitivo, lingotes de ferro pastoso facilmente forjáveis a partir de uma mistura de minério e carvão de lenha, sendo este o mais antigo produto sinterizado já evidenciado. Os egípcios fizeram ferramentas de aço utilizando-se técnicas de metalurgia do pó datadas de pelo menos 3.000 a.C., já os índios Incas antigos fizeram joias e artefatos a partir de pós de metais preciosos (Zapata, 1987; White, 1999).

O primeiro produto moderno obtido pela metalurgia do pó foi o filamento de tungstênio para lâmpadas elétricas incandescentes desenvolvido por volta de 1900. Em seguida vieram as ferramentas de corte de carboneto de tungstênio na década de 1920, partes de automóveis nos anos de 1960 e 1970, componentes de turbinas de aeronaves nos anos de 1980 e peças feitas por forjamento de pós, moldagem por injeção e compactação a quente nos anos de 1990 (Thümmler e Oberacker, 1993; German, 1994; White 1999).

O objetivo da técnica de metalurgia do pó é transformar (consolidar) pós metálicos ou não metálicos, usando pressão e calor, através de um tratamento térmico de sinterização, que é realizado a uma temperatura inferior ao ponto de fusão do metal base, para a obtenção de peças em sua forma final ou próxima dela. Esta técnica substituiu a fusão clássica (Howard, 1999). 
Este meio de produção é considerado um processo que conserva energia, pois aproximadamente $95 \%$ da matéria prima inicial é efetivamente utilizada para a obtenção da peça acabada, levando grande vantagem em relação a outros processos convencionais de produção, tais como fundição, forjamento a frio e a quente e usinagem. Além do mais, a técnica da metalurgia do pó é a que proporciona o menor gasto de energia, quando comparada aos mesmos métodos fabris durante o seu processo produtivo, como pode ser observado na FIG. 3.1 (Zapata, 1987; Thümmler e Oberacker, 1993).

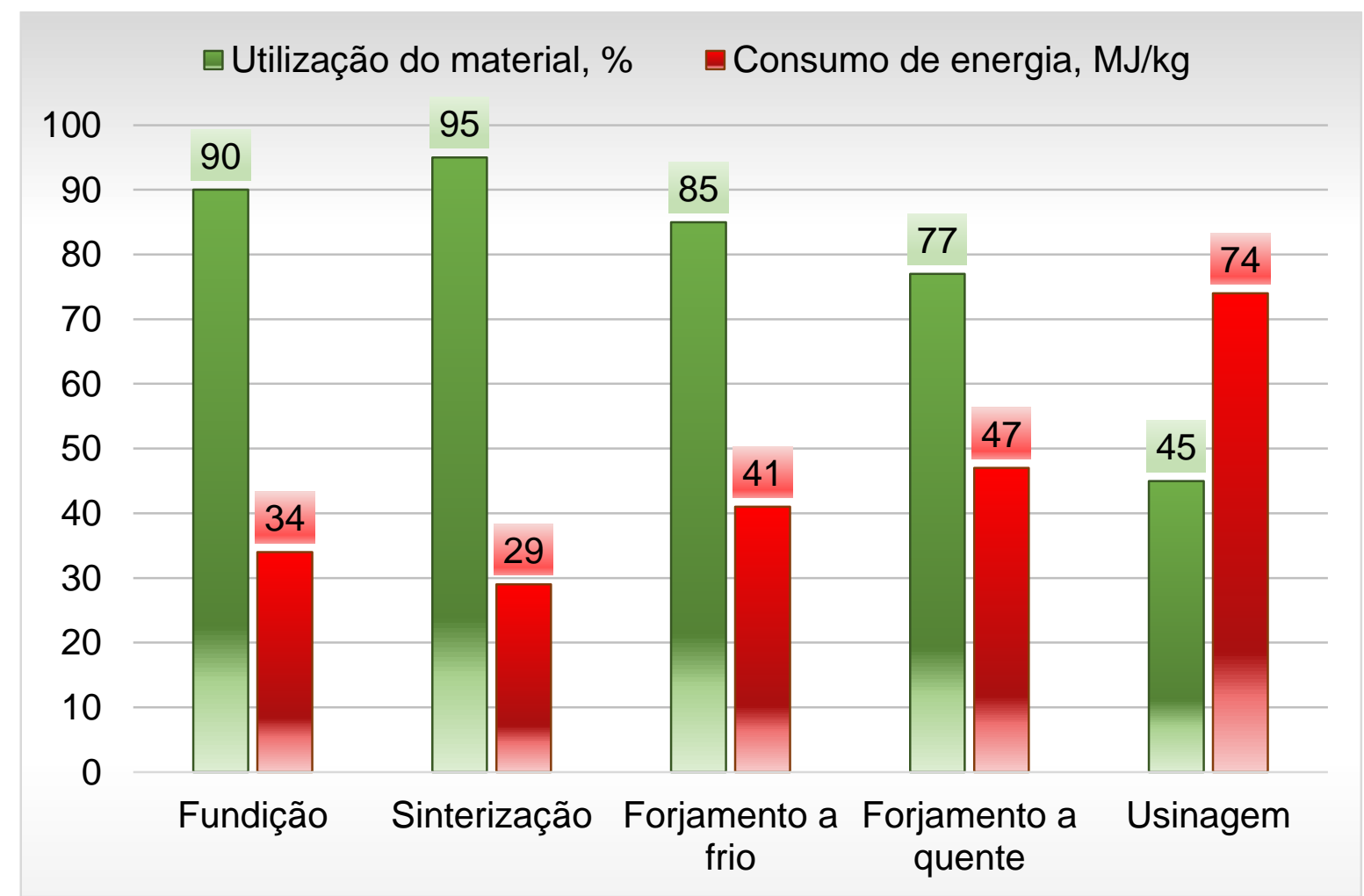

FIGURA 3.1 - Comparação entre o consumo de material e energia necessária para produzir-se $1 \mathrm{~kg}$ de produto acabado por meio de diferentes processos produtivos (Zapata, 1987; Thümmler e Oberacker, 1993).

A metalurgia do pó é uma técnica bastante efetiva para a produção de peças em larga escala. Na maioria dos casos proporciona a obtenção de componentes com dimensões próximas da projetada, com ótimo acabamento superficial e sem a necessidade de operações posteriores, tais como usinagem, retífica, entre outras (Chiaverini, 1992).

Em suma, esta técnica de produção é dividida em três etapas, sendo elas a mistura, compactação e sinterização. A operação de mistura consiste em 
obter-se a homogeneização das diversas matérias primas que irão compor o componente sinterizado, pós metálicos, elementos de liga e lubrificantes. A mistura deve atender à composição química especificada, além de se adequar às demais propriedades desejadas para a mistura de pós, tais como densidade aparente e escoabilidade (Orlandin et al., 2009).

A compactação é a etapa em que o pó é prensado no formato desejado, sendo esta a mais crítica de todo o processo de fabricação da peça. Uma compactação mal feita pode resultar na obtenção de componentes com variações excessivas de densidade, podendo assim, comprometer o desempenho do produto final (levorlino e Bulla, 2009).

Define-se sinterização como o processo pelo qual agregados de pós, compactados ou não, são transformados em corpos sólidos por mecanismos de transporte atômico difusionais a temperaturas abaixo do ponto de fusão do constituinte principal. Durante o processo ocorre a redução de energia livre do sistema através da diminuição da superfície específica do material. Resulta desta etapa a formação de contornos de grãos e crescimento de pescoço entre partículas, levando o sistema à densificação e consequentemente à contração volumétrica. Normalmente a temperatura de sinterização é da ordem de $2 / 3$ a 3/4 da temperatura de fusão do material base (Loberto et al., 2009). A FIG. 3.2 mostra, esquematicamente, as várias etapas da técnica de metalurgia do pó, incluindo as operações consideradas complementares (Chiaverini, 1992).

Um dos pré-requisitos mais importantes para o sucesso na produção de componentes de alta qualidade pela metalurgia do pó está associado principalmente à consistência e qualidade dos pós metálicos. É importante salientar que os pós metálicos e suas características influenciam diretamente o comportamento dos processos de compactação e sinterização e, como consequência, influenciam as propriedades funcionais do componente final (Orlandin et al., 2009). Os formatos dos pós metálicos variam significativamente com o tamanho e técnica de fabricação do pó. Além do mais, a forma da partícula influência o empacotamento, fluidez e compactação do pó (German, 1998). 


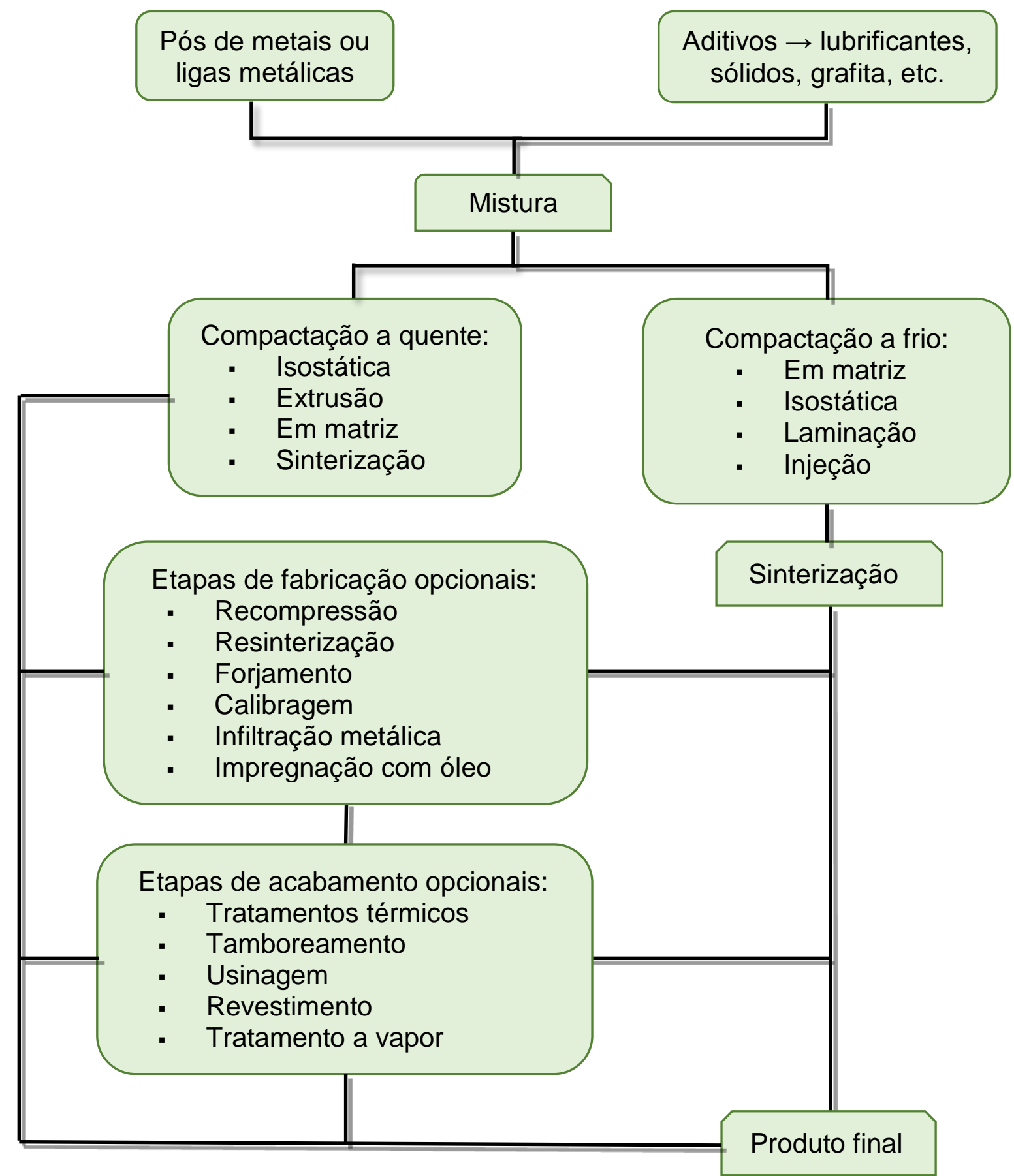

FIGURA 3.2 - Representação esquemática das várias etapas do processo de metalurgia do pó, adaptado de Chiaverini (1992).

O formato das partículas utilizadas em metalurgia do pó é de grande importância, visto que influenciam diretamente nas propriedades do pó, tais como compressibilidade, resistência a verde, sinterabilidade, entre outras. A obtenção de VSI pela técnica de metalurgia do pó utilizando-se partículas com o formato irregular resulta no aumento da resistência a verde do componente. $\mathrm{O}$ aumento da 
resistência a verde por sua vez, torna o controle dos VSI antes da sinterização menos rigorosos no que tange a sua manipulação (German, 2005).

Embora a metalurgia do pó seja tratada como um processo de obtenção de peças com dimensões próximas as definidas, algumas aplicações específicas requerem características especiais, sendo que estas somente são alcançadas através de operações posteriores. Dentre estas especificações especiais pode-se citar tolerâncias dimensionais estreitas, alta dureza, elevada resistência mecânica, estanqueidade a gases ou líquido, resistência à corrosão e boa aparência (Pallini et al., 2009).

A caracterização dos componentes após serem tratados termicamente é de grande importância. Somente adotando tal prática é possível avaliar as diversas propriedades exigidas dos componentes. Além do mais, a caracterização das amostras é importante para garantir um controle adequado de todas as etapas as quais os VSI foram submetidos durante sua obtenção (Trudel, 1988).

\subsection{Inserto de assento de válvula}

Inicialmente os assentos de válvulas eram usinados diretamente no corpo do cabeçote, mas foram sendo gradualmente substituídos por insertos fundidos de materiais mais nobres. Isto ocorreu devido a necessidade de se aumentar o rendimento dos motores automotivos mediante o aumento da taxa de compressão e melhor controle da mistura ar / combustível. Consequentemente, houve o aumento significativo da temperatura dos gases gerados após a queima da mistura de gases (Salgado, 2011).

O inserto de assento de válvula surgiu inicialmente como uma alternativa ao reparo de motores automotivos. Em 1926, Theodore Purnis, engenheiro de máquinas, foi nomeado coautor do VSI. Atualmente, este componente tornou-se indispensável aos motores de combustão interna, principalmente com a necessidade de redução de peso dos veículos, fazendo com que os blocos dos motores passassem a ser produzidos com materiais mais leves, por exemplo, o alumínio (Lee, 2017).

Parte do conjunto mecânico responsável por selar a câmara de combustão interna dos motores automotivos é constituído pela válvula e VSI, conforme mostrado na FIG. 3.3. 


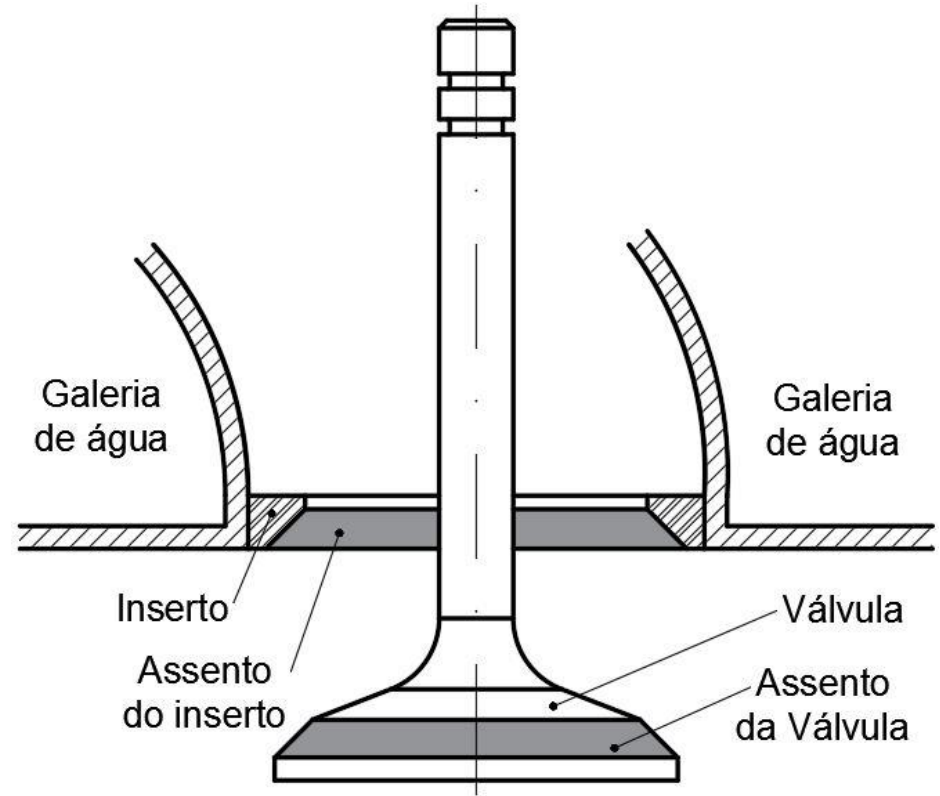

FIGURA 3.3 - Desenho esquemático indicando a distribuição espacial da válvula e do VSI em um motor de combustão interna.

O conjunto válvula / VSI representa um grande desafio do ponto de vista metalúrgico quando se busca aumentar o desempenho dos motores e reduzir os seus custos de produção. As condições severas às quais são submetidos esses componentes (altas tensões mecânicas, meio quimicamente agressivo, altas temperaturas, desgaste, erosão e corrosão) impõem uma série de variáveis que devem ser cuidadosamente consideradas (Salgado, 2011).

Os VS/são fabricados por meio de diversos materiais, por exemplo, ligas de cobre (Dalal et al., 1998; Kano et al., 2000), aços de alta liga (Kawata et al., 1998; Sato et al., 2000; Hayashi e Aoki, 2001; Ando et al., 2005; Kawata e Maki, 2006), insertos isentos de cobalto (Fujitsuka et al., 2004) e chumbo (Sakai, 2000).

\subsection{Ciclo térmico durante a operação do motor}

Em relação à variação de temperatura na câmara de combustão interna durante a operação dos motores, a região de mais alta temperatura ocorre sobre as superfícies de contato entre $\mathrm{o}$ assento da válvula e $\mathrm{o}$ assento do inserto. Estas superfícies de contato, por sua vez, somente ficam expostas aos gases superaquecidos com a abertura da válvula. Portanto, a exposição literal dos assentos da válvula e do inserto somente acontece na etapa de admissão e exaustão dos gases. Dentre estas etapas, o pico de aquecimento ocorre durante a explosão da mistura ar / combustível (Fujiki e Kano, 1992). 
Durante a etapa de admissão, há certo grau de refrigeração da câmara de combustão e seus componentes, devido à abertura da válvula e consequente entrada da mistura de gases (ar / combustível). Com isto, a temperatura máxima no assento da válvula chega a $350{ }^{\circ} \mathrm{C}$ e no assento do inserto a $250{ }^{\circ} \mathrm{C}$ (Fujiki e Kano, 1992).

Em temperaturas desta ordem dificilmente ocorre oxidação das superfícies de contato entre o assento da válvula e do VSI, mas pode ocorrer o desgaste severo devido ao contato entre as duas faces metálicas, sobretudo nos VSI que operam com combustível sem chumbo, pois este pode agir como lubrificante. Ressalta-se que a política ambiental adotada no Brasil não permite a sua utilização nos combustíveis (Burgos e Campos, 2003).

O caso mais crítico na superfície de contato entre a válvula e o VSI ocorre durante a etapa de exaustão dos gases, pois há o acúmulo de calor na câmara de combustão proveniente das etapas anteriores de compressão, combustão e expansão, onde a válvula sempre permanece fechada. Durante a exaustão a válvula permanece aberta, promovendo o aquecimento localizado nos assentos da válvula e do VSI. Neste caso, a temperatura no assento da válvula pode atingir a $700{ }^{\circ} \mathrm{C}$, e no assento do $\mathrm{VSI}$ a $350{ }^{\circ} \mathrm{C}$, sendo ambos os casos dependentes do nível de solicitação do motor (Fujiki e Kano, 1992).

Diferentemente da etapa de admissão, durante a exaustão dos gases há a possibilidade de ocorrer oxidação das superfícies de contato devido às elevadas temperaturas, o que torna a resistência à oxidação dos materiais envolvidos um requisito fundamental. Por outro lado, alguns óxidos atuam como lubrificantes ou camada de proteção superficial. Portanto, em termos de desgaste por deslizamento, o conjunto de exaustão não está sujeito à condições tão severas. Entretanto, mesmo para o sistema de exaustão, quando há utilização de combustível sem chumbo, não haverá formação de óxidos em quantidade suficiente para que a ação lubrificante possa prevalecer (Jesus Filho, 2006).

\subsection{Tratamentos térmicos}

Os tratamentos térmicos são utilizados para se adequar as fases, microestrutura e distribuição dos elementos de liga no material após a obtenção do componente. Quando aplicados à peças produzidas pela técnica de metalurgia do pó seguem os mesmos padrões já estabelecidos para o tratamento de materiais 
forjados e fundidos. Porém, os componentes obtidos por meio da metalurgia do pó sofrem alterações devido aos efeitos da porosidade residual (German, 1994).

Os poros reduzem a condutividade térmica do material, dificultando a extração do calor de forma rápida o bastante para que haja a formação da martensita. Consequentemente, a capacidade de endurecimento do material é reduzida proporcionalmente em relação a sua porosidade. Além do mais, todas as propriedades mecânicas são degradadas pela porosidade, resultando em baixa dureza, resistência mecânica, ductilidade e tenacidade do componente (German, 1998).

Diferentes tratamentos térmicos foram aplicados com a intenção de aumentar a dureza dos VSI e consequentemente sua resistência ao desgaste, pois ambas as propriedades estão intrinsecamente relacionadas (German, 1998; Colpaert, 2008). A têmpera, por exemplo, é realizada visando à formação de uma estrutura martensítica (ABNT, 2000).

Além de ótimos valores de dureza alcançados através da têmpera, os VSI também devem possuir boa resistência ao impacto, resistência mecânica, entre outras propriedades. Tais propriedades são melhoradas com o revenimento dos VSI após o tratamento de têmpera (Krauss, 1990), que possibilita a transformação parcial da martensita em ferrita e carbonetos (Sandvik, 1982; Taylor et al., 1989; German, 1998).

O revenimento é o tratamento térmico aplicado aos aços rápidos e aço ferramenta que consiste em reaquecer as peças previamente temperadas a temperaturas abaixo da linha inferior de transformação do aço (Chiaverini, 1988). Este tratamento é responsável por melhorar a tenacidade das microestruturas martensíticas temperadas, mas comitantemente, reduz a resistência mecânica e a dureza dos componentes (Krauss, 1990).

\subsection{Infiltração metálica}

A técnica de densificação de componentes sinterizados através da infiltração metálica já é algo estabelecido industrialmente e consiste em infiltrar os poros abertos do material com algum metal fundente durante ou após a sinterização (Dowson, 1990; German, 2005).

Os poros superficiais e os interconectados de um componente podem ser infiltrados, usualmente, com cobre ou ligas de cobre, tornando-o impermeável 
a gases e líquidos. O material infiltrante geralmente é fornecido na forma de pó e deve ser compactado em um formato adequado à peça em que será processado (levorlino e Bulla, 2009). O processo de infiltração metálica, ilustrado por meio da FIG. 3.4 (German, 2005), consiste em colocar uma pastilha do elemento infiltrante sobre o componente a ser infiltrado e inserir este conjunto no forno para sinterização acima de $1.100^{\circ} \mathrm{C}$ (Pallini, 2009).

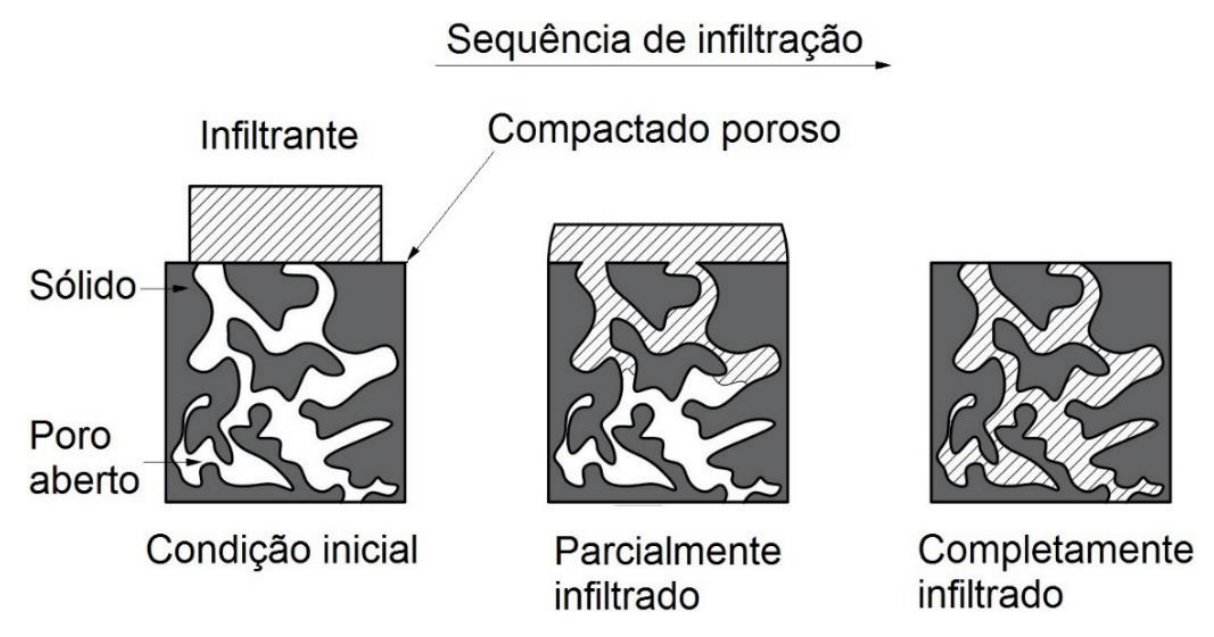

FIGURA 3.4 - Esboço da sequência de infiltração metálica, onde as forças capilares impulsionam o metal fundido para dentro dos poros abertos de um compactado poroso, adaptado de German (2005).

Em temperaturas próximas a $1.100^{\circ} \mathrm{C}$ as forças capilares pressionam o cobre fundido para dentro dos poros abertos do compactado, solidificando-se durante o resfriamento. Isto resulta na formação de um componente, possuindo sua estrutura de aço preenchida com cobre solidificado (German, 2005).

Durante a infiltração, o metal líquido pode reagir com o compactado e causar corrosão internamente. Além disso, dilatações térmicas podem ocorrer se o metal sólido e líquido reagirem. Por este motivo, a duração do ciclo de infiltração é curta para evitar grandes variações dimensionais (German, 2005).

Devido à estanqueidade decorrente da infiltração com o cobre e consequente melhoria da condutividade térmica do material, operações de tratamentos térmicos se tornam mais eficientes (Loberto et al., 2009). Além do mais, a infiltração metálica também aumenta a densidade e, por conseguinte, melhora as propriedades mecânicas do componente em questão (Pallini et al., 2009). 


\section{MATERIAIS E MÉTODOS}

Nesta seção elucidou-se cada uma das etapas de metalurgia do pó e seus respectivos parâmetros na obtenção de insertos de assentos de válvulas. Após a obtenção dos componentes, detalharam-se as etapas complementares que se seguiram, tais como têmpera ao ar, têmpera ao óleo e revenimento. Por fim, foi feita a caracterização dos VSI por meio da análise química, caracterização microestrutural e de suas propriedades físicas e mecânicas.

\subsection{Obtenção dos insertos de assentos de válvulas}

Os VSI utilizados no presente trabalho foram previamente obtidos por Santos (2014), que utilizou-se da técnica da metalurgia do pó para obter tais componentes. Os itens 4.1.1 a 4.1.5 foram sumarizados deste mesmo trabalho de Santos (2014).

\subsubsection{Materiais de partida}

Os VSI utilizados por Santos (2014) foram obtidos a partir de três misturas de pós diferentes. Os elementos comuns nestas três misturas foram os pós de ferro, sulfeto de manganês, carboneto de nióbio, grafite, estearato de zinco e cobre, sendo que este último foi adicionado por infiltração metálica (ver item 3.5).

Em cada mistura de pó variou-se apenas os tipos de pós de aços rápidos e aço ferramenta utilizado, sendo estes o aço rápido AISI M3:2 (Mistura 1), aço rápido AISI M2 (Mistura 2) e aço ferramenta AISI D2 (Mistura 3). Os elementos que compuseram os diferentes VSI estudados e suas respectivas composições químicas são apresentados na TAB. 4.1. 
TABELA 4.1 - Composição nominal (\% massa) das três misturas de pós.

\begin{tabular}{cccc}
\hline Pó & Mistura 1 & Mistura 2 & Mistura 3 \\
\hline AISI M3:2 & 43,60 & - & - \\
AISI M2 & - & 43,60 & - \\
AISI D2 & - & - & 43,60 \\
Fe & 43,60 & 43,60 & 43,60 \\
MnS & 0,50 & 0,50 & 0,50 \\
NbC & 2,00 & 2,00 & 2,00 \\
C (grafite) & 0,30 & 0,30 & 0,30 \\
Estearato de Zn & 0,80 & 0,80 & 0,80 \\
Cu (infiltração) & 10,00 & 10,00 & 10,00 \\
\hline
\end{tabular}

A TAB. 4.2 mostra a composição nominal de cada pó de aço rápido e aço ferramenta utilizado para a obtenção dos VSI (Totten, 2006).

TABELA 4.2 - Composição química nominal (\% massa) dos pós de aço rápido e aço ferramenta (Totten, 2006).

\begin{tabular}{cccc}
\hline Elemento & AISI M3:2 & AISI M2 & AISI D2 \\
\hline $\mathrm{C}$ & $1,15-1,25$ & $0,95-1,05$ & $1,40-1,60$ \\
$\mathrm{Mn}$ & $0,15-0,40$ & $0,15-0,40$ & 0,60 máx. \\
$\mathrm{Si}$ & $0,20-0,45$ & $0,20-0,45$ & 0,60 máx. \\
$\mathrm{Cr}$ & $3,75-4,50$ & $3,75-4,50$ & $11,00-13,00$ \\
$\mathrm{Ni}$ & 0,30 máx. & 0,30 máx. & 0,30 máx. \\
$\mathrm{Mo}$ & $4,75-6,50$ & $4,50-5,50$ & $0,70-1,20$ \\
$\mathrm{~W}$ & $5,00-6,75$ & $5,50-6,75$ & - \\
$\mathrm{V}$ & $2,75-3,75$ & $1,75-2,20$ & 1,10 máx. \\
$\mathrm{Fe}$ & Balanço & Balanço & Balanço \\
\hline
\end{tabular}

- Nihil

\subsubsection{Caracterização dos pós}

Todos os pós tiveram a distribuição do tamanho de partículas determinadas pela técnica de difração a laser por suspensão em água. Esta técnica consistiu em dispersar os pós em água contendo pirofosfato de sódio (agente 
dispersante) e, subsequente análise óptica do laser difratado pelas partículas de pós. Além do agente dispersante, o equipamento conta com um sistema de agitação por pás e ultrassom para separar e/ou evitar a formação de aglomerados.

Todos os pós utilizados no presente trabalho foram analisados quanto à sua morfologia através do MEV e classificados em relação a sua morfologia de acordo com o modelo proposto por German (2005).

\subsubsection{Mistura dos pós}

A mistura de pós foi realizada objetivando homogeneizar cada uma das três misturas de pós estudadas (ver TAB. 4.1), utilizando-se um misturador intensivo. Os parâmetros utilizados durante a mistura foram de $1.715 \mathrm{rpm}$ durante 5 minutos. Todos os pós de cada mistura foram colocados no misturador, exceto 0 pó de cobre, pois este foi adicionado posteriormente ao $\mathrm{VSI}$ através do processo de infiltração metálica (ver item 3.5).

\subsubsection{Compactação}

Após a homogeneização dos pós, estes foram compactados em uma prensa hidráulica de dupla ação instrumentada, atingindo a pressão de $700 \mathrm{MPa}$ durante o processo. Esta etapa resultou na obtenção de compactados a verde, possuindo o formato anelar com dimensões de $32,5 \times 25,5 \times 5,9 \mathrm{~mm}^{3}$, conforme mostrado na FIG. 4.1.

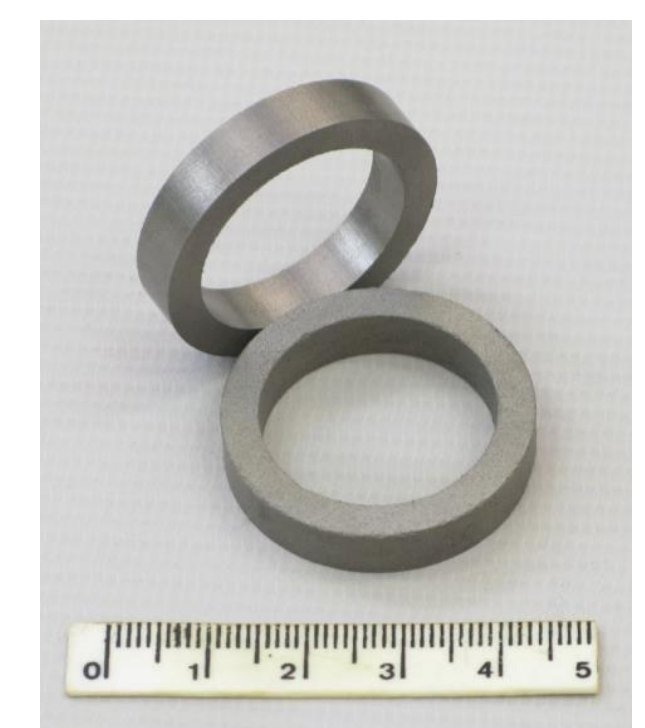

FIGURA 4.1 - VS/ compactados a verdes obtidos após a prensagem das diferentes misturas de pós a pressão de $700 \mathrm{MPa}$. 
Anéis de cobre (FIG. 4.2) foram obtidos com as mesmas condições de compactação dos VSI, exceto por sua espessura que foi redimensionada para resultar nas proporções ideais desejadas, sendo estas de $10 \%$ da massa do VSI compactado a verde. Tais componentes foram obtidos com o objetivo de serem utilizados posteriormente no processo de infiltração metálica, conforme detalhado no item 3.5.

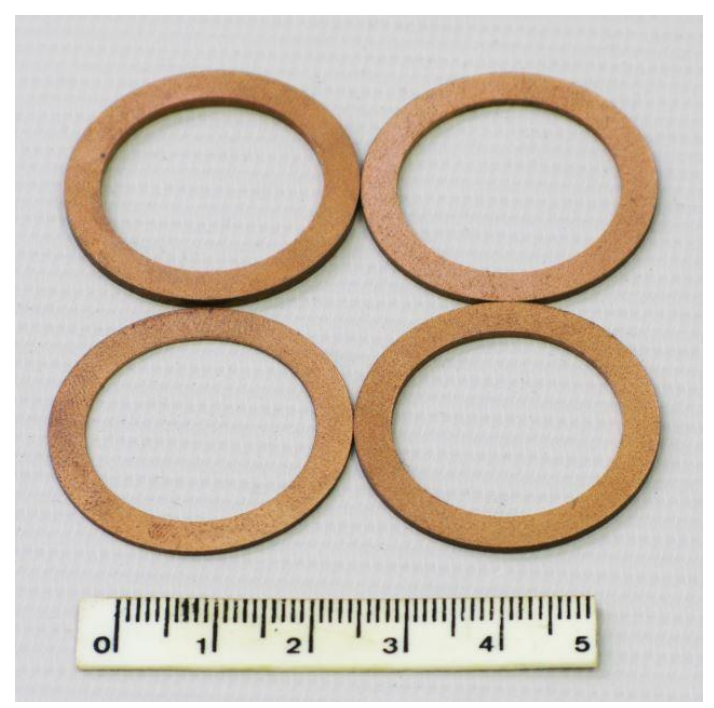

FIGURA 4.2 - Anéis de cobre compactados a verdes obtidos após a prensagem do pó de cobre a pressão de $700 \mathrm{MPa}$.

\subsubsection{Sinterização}

A sinterização dos compactados a verdes foi realizada em um forno comercial de esteira contínua sob uma atmosfera redutora composta predominantemente de hidrogênio $\left(90 \% \mathrm{H}_{2}+10 \% \mathrm{~N}_{2}\right)$ (Grupo Combustol \& Metalpó).

O processo de infiltração metálica tem início efetivamente antes da etapa de sinterização. O início do processo de sinterização consiste em colocar dois compactados a verde de anéis metálicos constituídos pelas três misturas de pós diferentes e pó de cobre sobrepostos, i.e., o compactado de cobre foi sobreposto em relação ao compactado do VSI, conforme mostra a FIG. 4.3. 


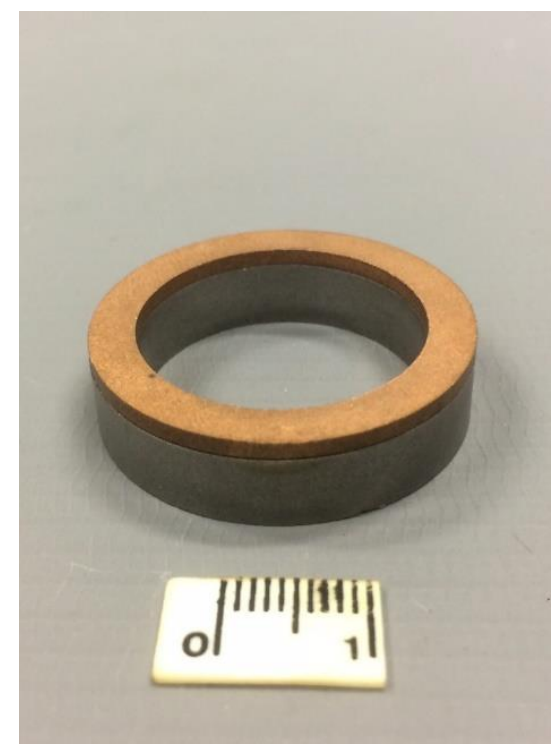

FIGURA 4.3 - Montagem do anel de cobre e VSI compactados a verde para a execução da etapa de infiltração metálica precedendo a etapa de sinterização.

Os compactados a verde foram pré-aquecidos a $600^{\circ} \mathrm{C}$ (com uma taxa de aquecimento de $17^{\circ} \mathrm{C} / \mathrm{min}$ ) durante $35 \mathrm{~min}$. para a eliminação do estearato de zinco. Na sequência, os $\mathrm{VSI}$ foram austenitizados à $1.150^{\circ} \mathrm{C}$ (aquecidos à 13,7 ${ }^{\circ} \mathrm{C} / \mathrm{min}$ ) por $40 \mathrm{~min}$. A austenitização compreende o processo de transformação microestrutural do aço pela elevação da temperatura acima da que se considera crítica (Chiaverini, 1988). Na última etapa da sinterização os VSI foram resfriados, ainda dentro do forno, até a temperatura ambiente com taxa média de resfriamento de $20^{\circ} \mathrm{C} / \mathrm{min}$.

\subsection{Tratamentos térmicos}

No presente trabalho, os VSI foram tratados por meio de dois tratamentos térmicos diferentes, sendo estes a têmpera ao ar e a têmpera ao óleo. Posteriormente, em ambos os casos, os VSI foram duplamente revenido. Para a execução dos diferentes tratamentos térmicos utilizou-se um forno mufla de laboratório. Almejando-se conter a descarbonetação das amostras devido ao contato com a atmosfera não controlada do forno mufla, os $\mathrm{VSI}$ foram colocados dentro de um recipiente de aço ao carbono contendo a mistura de $50 \%$ de grafite (C) e $50 \%$ de óxido de alumínio $\left(\mathrm{Al}_{2} \mathrm{O}_{3}\right)$, ambos na forma de pó (German, 1996). Esta mistura de pós foi a responsável por sofrer os efeitos da descarbonetação, algo inerente a este processo, ao invés dos componentes. 
Os VSI foram envoltos em folha sulfite, evitando assim o contato direto das amostras com a mistura de pós $\left(\mathrm{C}+\mathrm{Al}_{2} \mathrm{O}_{3}\right)$ que possivelmente ocasionaria a carbonetação dos VSI devido à presença de grandes quantidades de carbono. Após todos esses cuidados terem sido tomados, o recipiente de aço ao carbono fundido contendo as amostras foi colocado dentro do forno mufla para a realização do tratamento térmico. Então, os VSI foram austenitizados a $1.150{ }^{\circ} \mathrm{C}$ por $20 \mathrm{~min}$, sendo que estes foram aquecidos desde a temperatura ambiente até a temperatura de tratamento com a taxa média de $29^{\circ} \mathrm{C} / \mathrm{min}$.

\subsubsection{Têmpera ao ar}

Após a austenitização dos VSI, o recipiente de aço ao carbono contendo as amostras foi retirado do forno. Em sequência, as amostras foram retiradas do recipiente e resfriadas ao ar.

A têmpera ao ar é a forma menos drástica de têmpera. Portanto, somente nos componentes com uma pequena seção transversal, situação que se aplica aos VSI, o aço rápido irá ser resfriado de forma rápida o bastante para transformar a maior parte da estrutura do material nas condições martensíticas desejadas (Bayer e Becherer, 1989).

\subsubsection{Têmpera ao óleo}

Do mesmo modo que na têmpera ao ar, após a austenitização dos VSI, estes foram retirados do recipiente de aço ao carbono. Porém, as amostras foram resfriadas bruscamente, tendo sido mergulhadas em cerca de 8 litros de óleo do tipo SAE 15W 40, que estava contido em um recipiente circular.

A têmpera ao óleo confere ao material taxas de resfriamento intermediárias entre a têmpera ao ar e a têmpera na água (Krauss, 1990), resultando na obtenção de altos valores de dureza e, ao mesmo tempo, evitandose trincas causadas pelo elevado choque térmico entre a amostra e o meio de resfriamento da têmpera em água.

\subsubsection{Taxa de resfriamento}

A taxa de resfriamento é um dos fatores mais importantes durante o tratamento térmico, pois é ela quem determina a quantidade de martensita a ser 
formada e, portanto, o grau de dureza que se desenvolverá no material (Krauss, 1990). Para tanto, os ciclos de tratamentos térmicos foram determinados com 0 auxílio de termopar do tipo k afixado ao centro das amostras por meio do ajuste de interferência entre o furo feito na amostra e o revestimento em aço inoxidável externo do termopar (termopar embainhado). Para garantir a mesma taxa de resfriamento em todas as amostras, estas foram tratadas termicamente de uma só vez, ou seja, contidas todas no mesmo recipiente de tratamento térmico.

$\mathrm{Na}$ tentativa de prever as fases resultantes dos diferentes tratamentos térmicos para os aços rápidos e aço ferramenta, as curvas de resfriamento obtidas com o auxílio dos termopares durante as etapas de têmpera ao ar e têmpera ao óleo foram sobrepostas nos diagramas de tempo-temperatura-transformação (T.T.T.) e diagramas de transformação sob resfriamento contínuo (C.C.T.).

\subsubsection{Revenimento}

O uso da técnica de duplo revenimento é bastante usual, pois garante que a tenacidade do material seja melhorada, ainda mais, depois da mudança microestrutural induzida pela primeira etapa do revenimento. Portanto, as amostras foram duplamente revenida em sete temperaturas equidistantemente diferentes, variando-se de $100{ }^{\circ} \mathrm{C}$ a $700{ }^{\circ} \mathrm{C}$ (Nogueira, 2004; Dematté, 2006; Jesus Filho, 2014).

Cada etapa do revenimento consistiu em colocar as amostras no forno mufla, adotando o mesmo método utilizado para a têmpera ao ar e ao óleo, evitando assim a descarbonetação / carbonetação dos componentes. Após a definição da temperatura de revenimento, os VSI foram colocados dentro do forno mufla por 1 $\mathrm{h}$, em seguida, as amostras foram retiradas do forno e resfriadas ao ar até a temperatura ambiente. Depois repetiu-se este processo mais uma vez em cada faixa de temperatura.

\subsection{Caracterização dos insertos de assentos de válvulas}

Os VSI foram submetidos a diferentes métodos de caracterização, tais como a análise química, das suas propriedades físicas e mecânicas e microestrutural. Todos os itens supracitados foram colocados esquematicamente em um fluxograma (ver FIG. 4.4) para facilitar o entendimento dos métodos e a sequência adotada. 


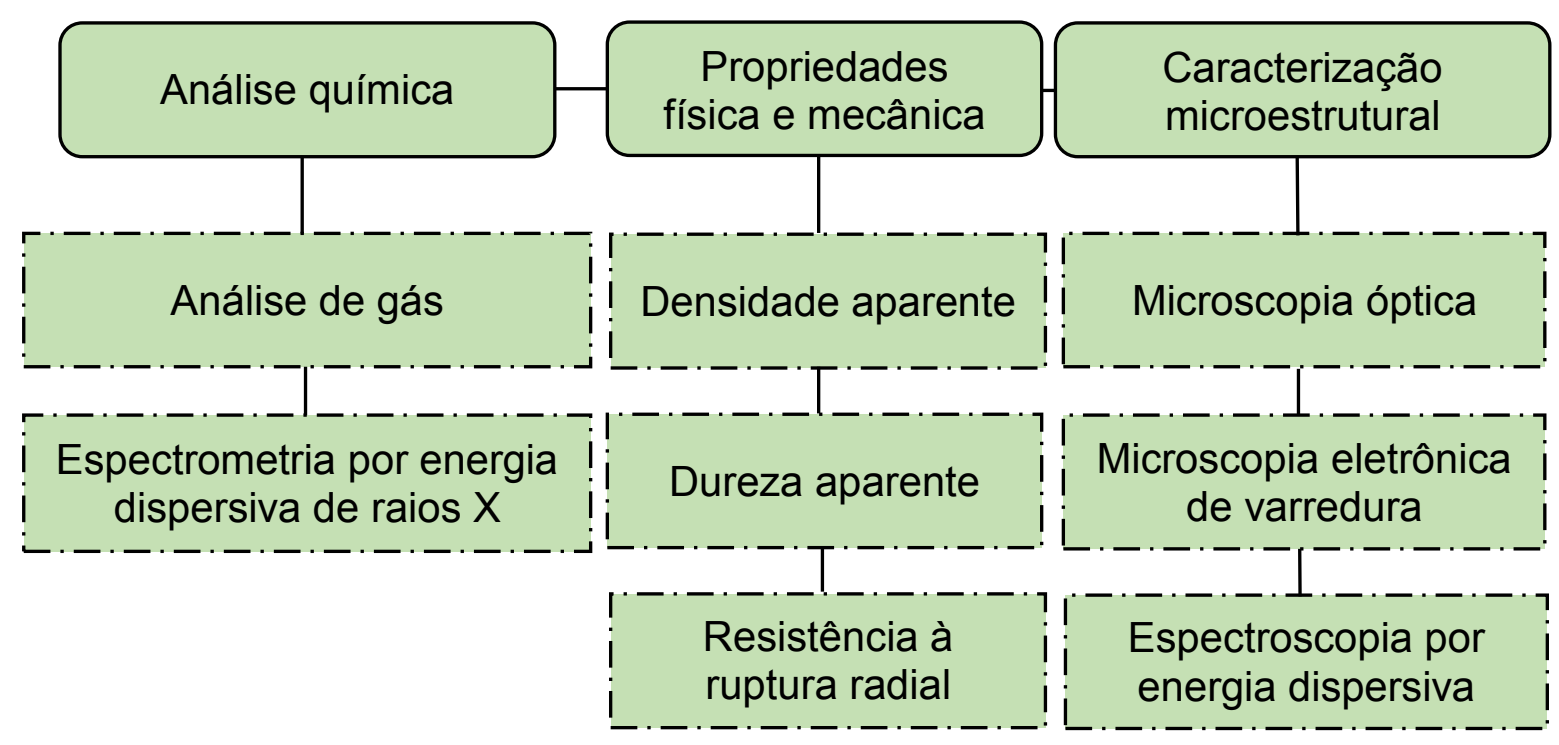

FIGURA 4.4 - Fluxograma dos métodos e sequência adotada para a caracterização dos VSI.

\subsubsection{Análise química}

A composição química dos $V S I$ foi determinada por meio da análise elementar e a espectrometria por energia dispersiva de fluorescência de raios $X$ (EDXRFS). A técnica de análise elementar de gases foi utilizada para a quantificação dos elementos leves, tais como carbono e enxofre. Os outros elementos presentes no componente (ver TAB. 4.1) foram quantificados através da análise por EDXRFS.

Em ambas as análises realizaram-se três medidas em cada amostra, tornando possível avaliar o grau de dispersão dos valores medidos. Então, foi possível calcular a média e desvio padrão dos valores medidos em cada amostra (Pinheiro, 2009).

\subsubsection{Propriedades físicas e mecânicas}

Os VSI foram avaliados quanto as suas propriedades físicas e mecânicas através de três técnicas principais, sendo estas utilizadas para a determinação da dureza aparente, densidade aparente e resistência à ruptura radial.

A dureza aparente dos VSI foi determinada de acordo com o padrão ASTM E 10-01 (2004). Este teste padronizado é utilizado para a determinação da dureza Brinell em materiais metálicos. A dureza aparente dos componentes foi 
medida com esfera de $\varnothing 2,5 \mathrm{~mm}$ e carga de $187,5 \mathrm{kgf}$ aplicada durante $15 \mathrm{~s}$, de acordo com a norma estas condições podem ser expressas por HB 2,5 / 187,5. Foram feitas cinco medidas para cada amostra e descartou-se o menor valor de dureza encontrado (Figueira Filho, 2016), sendo que os valores de dureza foram obtidos por meio da Eq. 1.

$$
H B=\frac{2 \cdot F}{\pi \cdot D\left(D-\sqrt{D^{2}-d^{2}}\right)}
$$

Onde:

$$
\begin{aligned}
& \mathrm{HB}=\text { dureza Brinell [HB] } \\
& F=\text { carga utilizada no ensaio }[\mathrm{kgf}] \\
& D=\text { diâmetro da esfera [mm] } \\
& d=\text { diâmetro médio da identação [mm] }
\end{aligned}
$$

A densidade aparente dos VSI foi medida utilizando-se do método de Arquimedes, que consiste em imergir os componentes em água e medir sua diferença de massa úmida e seca, conforme especificado no ensaio ASTM C 37388 (2004).

$$
\mathrm{D}=\left(\frac{\mathrm{m}_{\text {seca }}}{\mathrm{m}_{\text {úmida }}-\mathrm{m}_{\text {imersa }}}\right) \cdot \mathrm{d}_{\text {água }}
$$

Onde:

$\mathrm{D}=$ densidade aparente $\left[\mathrm{g} \cdot \mathrm{cm}^{-3}\right]$

$\mathrm{m}_{\text {seca }}=$ massa da amostra seca $[\mathrm{g}]$

múmida = massa da amostra úmida [g]

mimersa = massa da amostra quando imersa em água [g]

dágua $=$ densidade da água $\left[\mathrm{g} \cdot \mathrm{cm}^{-3}\right]$

O ensaio de resistência à ruptura radial foi realizado de acordo com o teste padrão MPIF 35 (2009). Este ensaio consiste em comprimir radialmente o VSI até que a primeira queda de carga ocorra, pois a ruptura do material pode ser tanto externamente quanto internamente, não sendo visível as trincas oriundas da 
ruptura à vista desarmada. A resistência à ruptura radial dos anéis metálicos foi calculada por meio da Eq. 3.

$$
K=P \cdot\left(\frac{D-e}{L . e^{2}}\right)
$$

Onde:

$$
\begin{aligned}
& \mathrm{K}=\text { resistência à ruptura radial }[\mathrm{MPa}] \\
& \mathrm{P}=\text { carga máxima suportada antes da primeira ruptura }[\mathrm{N}] \\
& \mathrm{D}=\text { diâmetro externo do } \mathrm{VSI}[\mathrm{mm}] \\
& \mathrm{e}=\text { espessura da parede do } \mathrm{VSI}[\mathrm{mm}] \\
& \mathrm{L}=\text { altura do } \mathrm{VSI}[\mathrm{mm}]
\end{aligned}
$$

\subsubsection{Caracterização microestrutural}

Durante a caracterização dos VSI quanto a sua microestrutura, foi necessário embuti-los. Para isto, utilizou-se a resina de cura a frio, por liberar baixa quantidade de calor sobre a amostra e, ser um método prático de embutimento.

Posteriormente, as amostras foram preparadas por meio de métodos convencionais de metalografia. Tais métodos consistiram em preparar as amostras com lixas de diferentes granulometrias, P220, P320, P400, P600, P1.200 e P2.400, e em seguida, sendo polidas em panos contendo pastas de diamantes de $6 \mu \mathrm{m}$ e 1 $\mu \mathrm{m}$.

A caracterização microestrutural propriamente dita foi realizada com 0 auxílio de duas técnicas diferentes, após o ataque químico, como será descrito adiante. Primeiro, a análise foi feita com o auxílio da microscopia óptica (MO), tornando possível a observação da estrutura dos grãos, seus formatos e também fases secundárias presentes nos VSI. A segunda técnica consistiu em utilizar a microscopia eletrônica de varredura (MEV), utilizada no modo de detecção de elétrons retroespalhados (BSE), possuindo o detector de espectroscopia por energia dispersiva (EDS) que tornou possível a identificação dos elementos e fases presentes na microestrutura dos VSI.

A observação das diferentes fases formadas foi possível após atacar as amostras com Nital 3\%, sendo este constituído de 97\% (vol.) de álcool etílico e 3\% (vol.) de ácido nítrico $\left(\mathrm{HNO}_{3}\right)$ concentrado. As amostras foram atacadas durante 5 s (Colpaert, 2008) enquanto estavam sendo analisadas por meio do MO, e durante 
a análise microestrutural com o suporte do MEV, as amostras foram sobre atacadas por 50 s (Höganäs, 2007).

Em todas as análises por MEV foi necessário sobre atacar as amostras, pois somente assim foi possível discernir entre a matriz dos aços rápidos e aço ferramenta e a matriz ferrítica, pois ambos os elementos foram adicionadas em quantidades similares (ver TAB. 4.1), e estes reagem de maneiras distintas frente ao mesmo ataque. 


\section{RESULTADOS E DISCUSSÃO}

Os resultados e discussão tiveram início com a caracterização do material de partida. Em seguida, avaliou-se os resultados obtidos para os VSI apenas como sinterizados, temperados ao ar, temperados ao óleo, e duplamente revenido. Para auxiliar nos tratamentos térmicos utilizou-se diagramas de transformações de fase em condições de não equilíbrio. Os componentes foram caracterizados por meio da análise química, dureza aparente, densidade aparente e resistência à ruptura radial. Com base nas fases previstas que resultaram dos tratamentos térmicos e os resultados da avaliação microestrutural correlacionaramse as diferentes microestruturas formadas com suas respectivas propriedades físicas e mecânicas.

\subsection{Caracterização dos pós}

Os gráficos das distribuições dos tamanhos de partículas obtidos durante a análise por dispersão dos pós em água e difração a laser para cada tipo de pó são mostrados por meio da TAB. 5.1. Dos referidos gráficos, é possível inferir que a maioria dos pós metálicos apresentaram distribuição bimodal assimétrica, sendo este o caso dos pós de aço rápido AISI M3:2, aço rápido AISI M2, aço ferramenta AISI D2, ferro, sulfeto de manganês e carboneto de nióbio.

Para o sulfeto de manganês e carboneto de nióbio a dispersão e assimetria da distribuição do tamanho de partícula é muito mais acentuada. Isto pode ser relacionado com a presença de dois elementos diferentes em cada um desses pós, sendo estes o MnS e o NbC. Já para os pós de grafite e cobre podese observar que há uma distribuição modal e pouco dispersa, inclusive havendo uma semelhança no tipo de distribuição. 
TABELA 5.1 - Gráficos das distribuições dos tamanhos de partículas obtidos por difração a laser dos seguintes pós: $(A A)$ aço rápido $A I S I ~ M 3: 2,(A B)$ aço rápido AISI M2, (BA) aço ferramenta AISI D2, (BB) ferro, (CA) sulfeto de manganês, (CB) carboneto de nióbio, (DA) grafite e (DB) cobre.

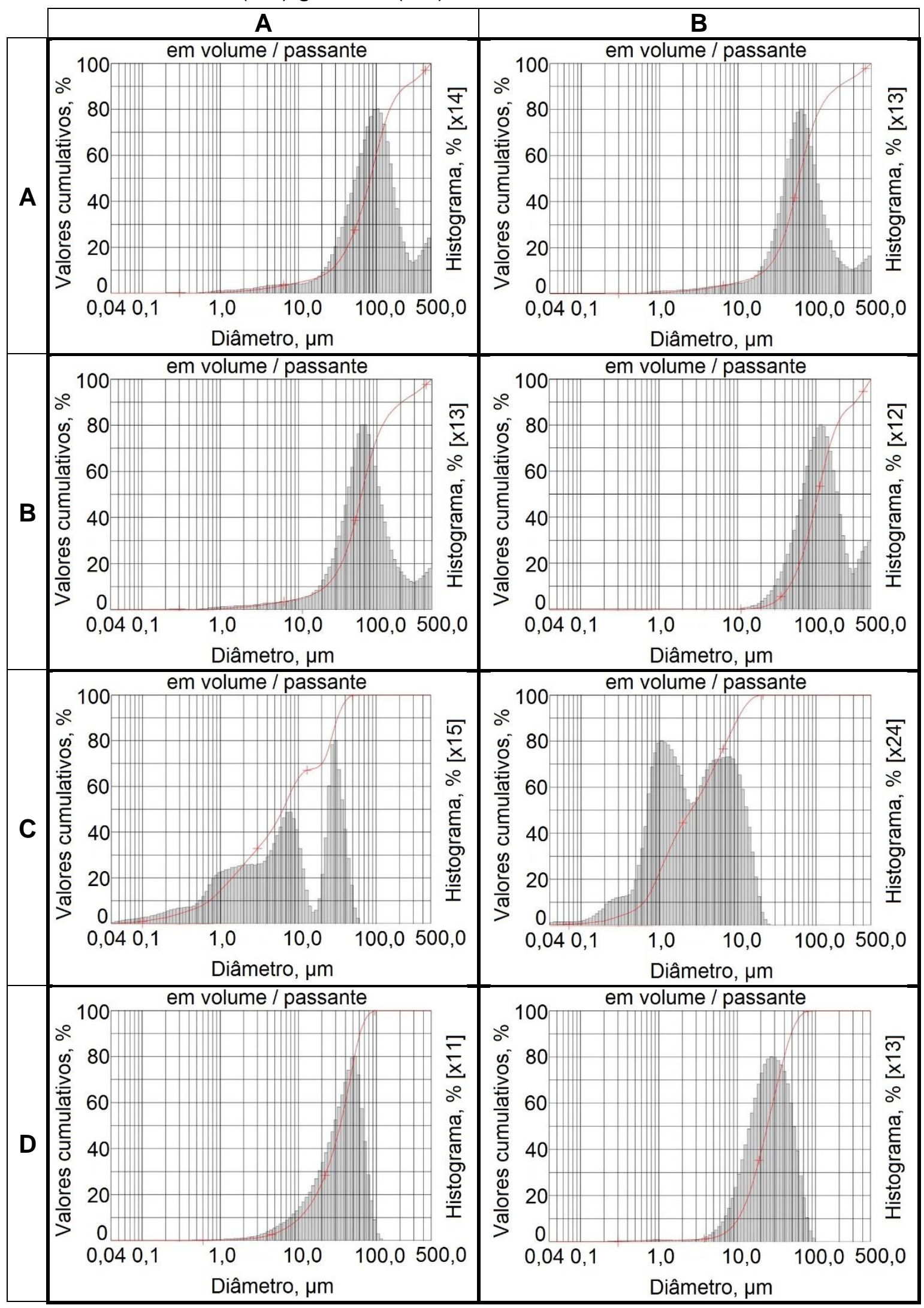


Almejando-se facilitar o entendimento dos dados apresentados na TAB. 5.1, realizou-se a compilação de todas estas informações da distribuição do tamanho de partícula na TAB. 5.2.

TABELA 5.2 - Compilação dos dados da distribuição do tamanho de partícula dos diferentes pós utilizados obtidos por difração a laser.

\begin{tabular}{ccccc}
\hline Partícula / parâmetro $(\mu \mathrm{m})$ & $\mathrm{D}_{10}$ & $\mathrm{D}_{50}$ & $\mathrm{D}_{90}$ & Diâmetro médio \\
\hline AISI M3:2 & 25,74 & 83,86 & 239,39 & 112,33 \\
AISI M2 & 21,82 & 60,33 & 194,84 & 90,10 \\
AISI D2 & 21,95 & 63,57 & 207,98 & 93,99 \\
Fe & 45,63 & 106,28 & 317,59 & 139,83 \\
MnS & 0,72 & 6,38 & 32,00 & 12,27 \\
NbC & 0,63 & 2,53 & 10,12 & 4,12 \\
C (grafite) & 10,41 & 34,30 & 61,57 & 35,51 \\
Cu (infiltração) & 10,26 & 24,26 & 48,88 & 27,25 \\
\hline
\end{tabular}

A caracterização morfológica dos diferentes pós estudados neste trabalho (ver TAB. 4.1) foi feita por meio do MEV, que consistiu em analisar a forma das diferentes partículas em questão, conforme detalhado na TAB. 5.3. A morfologia das partículas foi classificada de acordo com o modelo proposto por German (2005).

A morfologia do pó tem grande influência nas propriedades finais dos componentes obtidos. Porém, diversos outros fatores dos pós também devem ser analisados cautelosamente, tais como a compressibilidade, dureza, escoabilidade, fator de empacotamento, entre outros. Os pós de aço rápido AISI M3:2 (AA) e ferro (BB) aproximam-se da morfologia irregular sugerida por German (2005), o que geralmente acarreta na maior resistência a verde dos componentes obtidos com este tipo de pó.

Já as partículas do pó de aço rápido AISI M2 $(A B)$ e aço ferramenta AISI D2 (BA) apresentam um formato esférico, que por sua vez costuma melhorar a escoabilidade e empacotamento de tais partículas. A característica dos pós compostos por dois elementos, sendo estes o sulfeto de manganês (CA) e carboneto de nióbio (CB), apresentaram um aspecto morfológico de aglomerados. As partículas de grafite (DA) apresentaram-se no formato de flocos. 
TABELA 5.3 - Micrografia obtida por MEV mostrando a morfologia dos seguintes pós: (AA) aço rápido AISI M3:2, (AB) aço rápido AISI M2, (BA) aço ferramenta AISI $\mathrm{D} 2$, (BB) ferro, (CA) sulfeto de manganês, (CB) carboneto de nióbio e (DA) grafite.

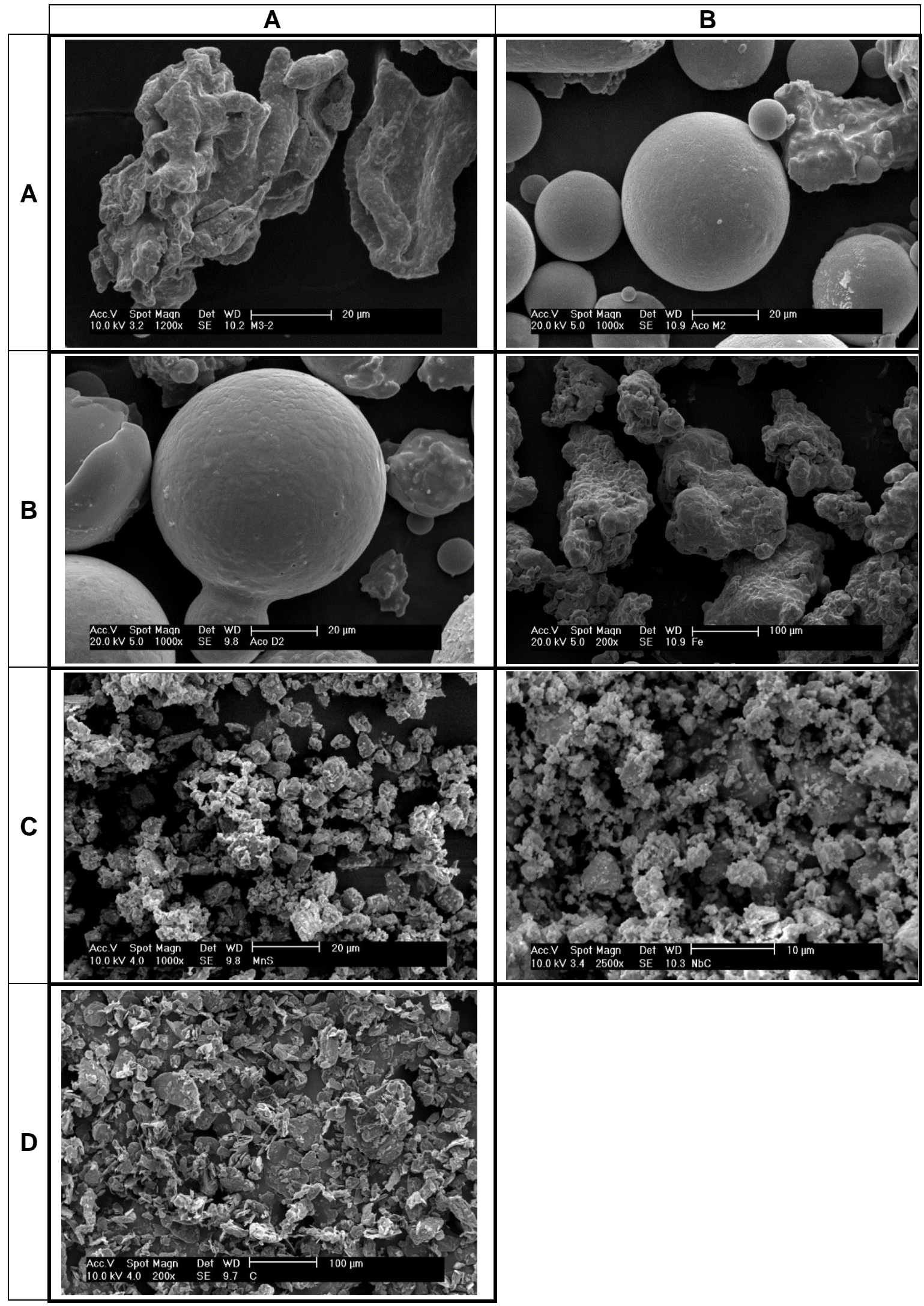




\subsection{Análise química}

A composição química medida para os VSI é mostrada na TAB. 5.4. Os teores de carbono e enxofre foram determinados através da análise elementar e todos os outros elementos foram medidos utilizando-se a técnica de EDXRFS. Variações consideráveis nos teores de cobre podem ser observadas para todas as amostras em relação ao valor nominal presente em cada VSI (ver TAB. 4.1).

TABELA 5.4 - Composição química (\% massa), obtida por análise elementar e por EDXRFS, dos VSI obtidos com as três misturas de pós diferentes. Os teores de carbono e enxofre foram determinados usando a técnica de análise elementar e os outros elementos foram determinados por EDXRFS.

\begin{tabular}{cccc}
\hline Elemento & Mistura 1 & Mistura 2 & Mistura 3 \\
\hline Fe & $75,74 \pm 0,12$ & $73,52 \pm 0,02$ & $77,56 \pm 0,02$ \\
Cu & $12,54 \pm 0,05$ & $15,04 \pm 0,01$ & $11,79 \pm 0,02$ \\
Mo & $2,87 \pm 0,01$ & $2,77 \pm 0,01$ & $0,52 \pm 0,01$ \\
W & $1,97 \pm 0,02$ & $1,62 \pm 0,01$ & - \\
Cr & $1,83 \pm 0,01$ & $2,09 \pm 0,01$ & $5,71 \pm 0,01$ \\
Nb & $1,68 \pm 0,01$ & $2,03 \pm 0,03$ & $1,63 \pm 0,01$ \\
V & $1,21 \pm 0,01$ & $0,79 \pm 0,01$ & $0,45 \pm 0,01$ \\
Mn & $0,73 \pm 0,06$ & $0,78 \pm 0,06$ & $0,52 \pm 0,01$ \\
Si & $0,29 \pm 0,12$ & $0,27 \pm 0,07$ & $0,27 \pm 0,02$ \\
C & $1,03 \pm 0,02$ & $0,97 \pm 0,03$ & $1,45 \pm 0,03$ \\
S & $0,11 \pm 0,03$ & $0,12 \pm 0,02$ & $0,10 \pm 0,02$ \\
\hline
\end{tabular}

O valor esperado para a quantidade de cobre era de $10 \%$, mas os valores medidos variaram entre $11,79 \%$ e $15,04 \%$. É fato que esta variação na massa do cobre esteja atrelada a etapa de compactação dos VSI e anéis de cobre (ver item 4.1.4), pois a massa dos anéis de cobre deveria ser exatamente de $10 \%$ em relação a massa do $V S I$. Os $V S I$ e anéis de cobre deveriam ser precisamente pesados e pareados, portanto, o pareamento inadequado do conjunto VSI e anel de cobre foi a causa de tal variação. 


\subsection{Têmpera ao ar}

\subsubsection{Propriedades físicas e mecânicas}

A variação da dureza aparente medida para os VSI apenas como sinterizados e também temperados ao ar e duplamente revenido em sete temperaturas diferentes, $1 \mathrm{~h}$ em cada temperatura especificada e depois resfriados ao ar é mostrada na FIG. 5.1.

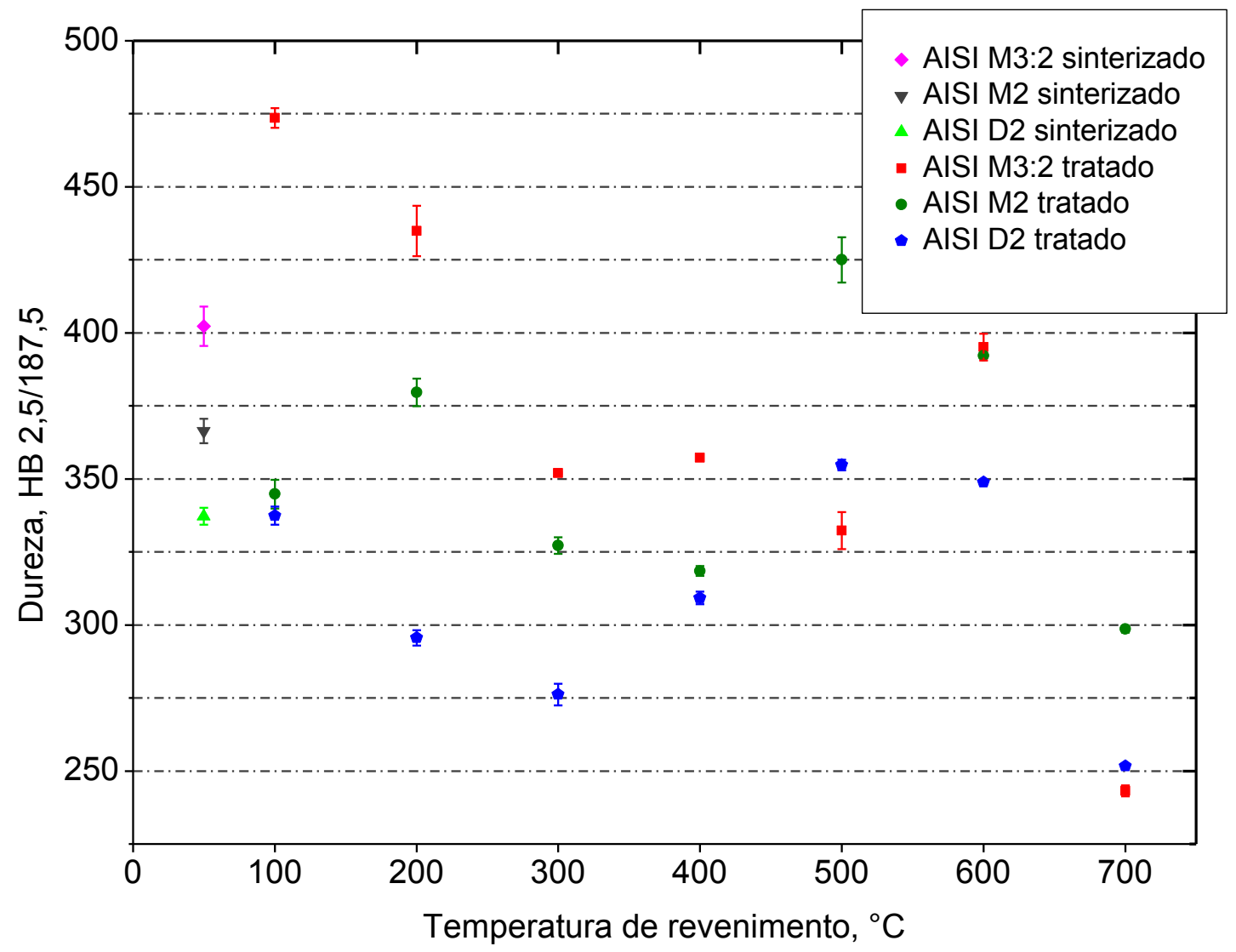

FIGURA 5.1 - Variação da dureza Brinell (HB 2,5 / 187,5) nos VSI apenas como sinterizados e também nos componentes temperados ao ar e duplamente revenido em sete temperaturas diferentes.

De acordo com o gráfico é possível notar uma variação considerável na dureza aparente dos VSI, e estes dados são representados mais facilmente por meio da TAB. 5.5. 
TABELA 5.5 - Variação da dureza Brinell (HB 2,5 / 187,5) nos VSI apenas como sinterizados e também nos componentes temperados ao ar e duplamente revenido em sete temperaturas diferentes.

\begin{tabular}{lcccccccc}
\hline & & \multicolumn{7}{c}{ Temperatura de duplo revenimento $\left({ }^{\circ} \mathrm{C}\right)$} \\
\cline { 3 - 9 } Mistura & Sinterizado & 100 & 200 & 300 & 400 & 500 & 600 & 700 \\
\hline \multirow{2}{*}{ Mistura 1 } & 402 & 474 & 435 & 352 & 357 & 332 & 395 & 243 \\
& \pm 7 & \pm 3 & \pm 9 & \pm 1 & \pm 1 & \pm 6 & \pm 5 & \pm 2 \\
Mistura 2 & 366 & 345 & 380 & 327 & 318 & 425 & 392 & 299 \\
& \pm 4 & \pm 5 & \pm 5 & \pm 3 & \pm 2 & \pm 8 & \pm 1 & \pm 1 \\
Mistura 3 & 337 & 337 & 296 & 276 & 309 & 355 & 349 & 252 \\
& \pm 3 & \pm 3 & \pm 3 & \pm 4 & \pm 2 & \pm 2 & \pm 1 & \pm 1 \\
\hline
\end{tabular}

A tolerância na variação da dureza aparente para aplicação comercial dos VSI determina que esta deva estar entre $370 \mathrm{HB}$ e $410 \mathrm{HB}(2,5 / 187,5)$. Os valores de dureza aparente mais próximos dessa faixa foram de $395 \pm 5$ e $392 \pm 1$ para a Mistura 1 (AISI M3:2) e Mistura 2 (AISI M2), respectivamente, duplamente revenida a $600^{\circ} \mathrm{C}$. Já para a Mistura 3 (AISI D2), este valor foi de $355 \pm 2$ para as amostras duplamente revenida a $500^{\circ} \mathrm{C}$.

Cabe ressaltar que os VSI obtidos com a Mistura 1, sendo apenas sinterizados, atingiram a faixa de dureza aparente exigida pelo fabricante de motores, com o valor de $402 \pm 7 \mathrm{HB}$. Entretanto, para a Mistura 2 e Mistura 3, os componentes apenas como sinterizados não atendem as especificações mínimas. Desta forma, foi necessário tratar termicamente tais componentes. É importante salientar que todos os resultados e discussão mostrados a seguir focaram nos VSI com melhores respostas aos tratamentos térmicos aplicados, conforme destacado anteriormente.

Além da dureza aparente ser uma propriedade mecânica muito importante aos VSI, outras duas propriedades físicas são tão importantes quanto. Estas propriedades são a densidade aparente e a resistência à ruptura radial. Os valores medidos durante a avaliação das principais propriedades físicas e mecânicas dos $\mathrm{VSI}$ que melhor responderam aos tratamentos térmicos de têmpera ao ar e duplo revenimento são mostrados na TAB. 5.6. 
TABELA 5.6 - Principais propriedades físicas e mecânicas dos VSI obtidos com a Mistura 1 (AISI M3:2), Mistura 2 (AISI M2) e Mistura 3 (AISI D2), temperados ao ar e duplamente revenido a $600^{\circ} \mathrm{C}, 600^{\circ} \mathrm{C}$ e $500{ }^{\circ} \mathrm{C}$, respectivamente.

\begin{tabular}{cccc}
\hline Mistura & $\begin{array}{c}\text { Dureza aparente } \\
\text { HB 2,5 / 187,5 }\end{array}$ & $\begin{array}{c}\text { Densidade aparente } \\
\text { g.cm }\end{array}$ & $\begin{array}{c}\text { Resistência à ruptura radial } \\
\text { MPa }\end{array}$ \\
\hline Mistura 1 & $395 \pm 5$ & $7,2 \pm 0,3$ & $997 \pm 30$ \\
Mistura 2 & $392 \pm 1$ & $7,4 \pm 0,3$ & $579 \pm 92$ \\
Mistura 3 & $355 \pm 2$ & $7,3 \pm 0,1$ & $792 \pm 57$ \\
\hline
\end{tabular}

O trabalho desenvolvido por Jesus Filho (2006) consistiu na obtenção de VSI utilizando-se o pó de aço rápido AISI M3:2. Ao longo do referido trabalho analisou-se os componentes apenas como sinterizados. Os valores de densidade aparente e resistência à ruptura radial medidos por Jesus Filho foram de $7,33 \mathrm{g.cm}-$ ${ }^{3}$ e $1.268 \mathrm{MPa}$, respectivamente. Estes, por sua vez, foram maiores em relação aos encontrados para a Mistura 1 (AISI M3:2), tendo sido de 7,2 g.cm e $997 \mathrm{MPa}$, respectivamente. Por outro lado, os valores de dureza aparente medidos por Jesus Filho, $380 \pm 25 \mathrm{HB}$, foram menores do que os valores medidos no presente trabalho para as amostras tratadas termicamente, $395 \pm 5 \mathrm{HB}$.

A obtenção de $\mathrm{VSI}$ com as mesmas misturas de pós utilizadas no atual estudo foi realizada por Santos et al. (2014 e 2016), sendo que tais componentes foram analisados apenas como sinterizados. Os valores de densidade aparente medidos por Santos ficaram próximos dos obtidos para a Mistura 2 e Mistura 3, sendo de 7,4 g.cm-3 e 7,3 g.cm-1, respectivamente. As medidas de dureza aparente de Santos, $345 \pm 21 \mathrm{HB}$ e $325 \pm 22 \mathrm{HB}$, foram menores do que os valores obtidos no presente trabalho para a Mistura 2 e Mistura 3, $392 \pm 1$ e $355 \pm 2 \mathrm{HB}$, respectivamente.

Os valores de resistência à ruptura radial obtidos por Santos, $595 \pm 48$ $\mathrm{MPa}$ e $945 \pm 81 \mathrm{MPa}$, foram maiores do que os medidos neste trabalho, $579 \pm 92$ $\mathrm{MPa}$ e $792 \pm 57 \mathrm{MPa}$, para a Mistura 2 e Mistura 3, respectivamente. Embora os valores de resistência à ruptura radial sejam menores em relação aos medidos no trabalho desenvolvido por Santos, esta propriedade somente é necessária durante a montagem do VSI nos cabeçotes dos motores automotivos. Portanto, não há algum valor mínimo definido para tal resistência, o componente somente precisa suportar a etapa de montagem. 


\subsubsection{Diagramas de transformação de fase}

Todos os VSI foram resfriados continuamente, possibilitando assim o uso de diagramas de transformação de fase para prever as transformações microestruturais durante o tratamento térmico. Para garantir a mesma taxa de resfriamento em todos os componentes, estes foram colocados no mesmo recipiente e tratados termicamente de uma só vez.

A taxa de resfriamento obtida durante todo o ciclo de têmpera ao ar foi medida com termopares do tipo $\mathrm{k}$ acoplados à amostra e ao sistema de aquisição de dados. A taxa média de resfriamento obtida foi de $0,6{ }^{\circ} \mathrm{C} / \mathrm{s}$. As curvas de resfriamento geradas foram posteriormente sobrepostas nos diagramas de transformações de fases identificadas como linhas traço-dois pontos. Portanto, de acordo com a forma de resfriamento adotada utilizou-se diagramas de transformações sob resfriamento contínuo (C.C.T.) encontrados na literatura para o aço rápido AISI M2 e aço ferramenta AISI D2 (Vander Voort, 1991).

Foi utilizado um diagrama de transformação isotérmica (do inglês I.T. ou T.T.T.) para o aço rápido AISI M3:2 (FIG. 5.2), devido às dificuldades para encontrar-se diagramas C.C.T. para este material. De acordo com Totten (2006) tal consideração pode ser feita, pois "quando comparando as curvas de início da transformação em diagramas C.C.T. e T.T.T. para o mesmo aquecimento e material, é constatado que nos diagramas C.C.T. as curvas são ligeiramente deslocadas para tempos longos e temperaturas baixas" grifo do presente autor.

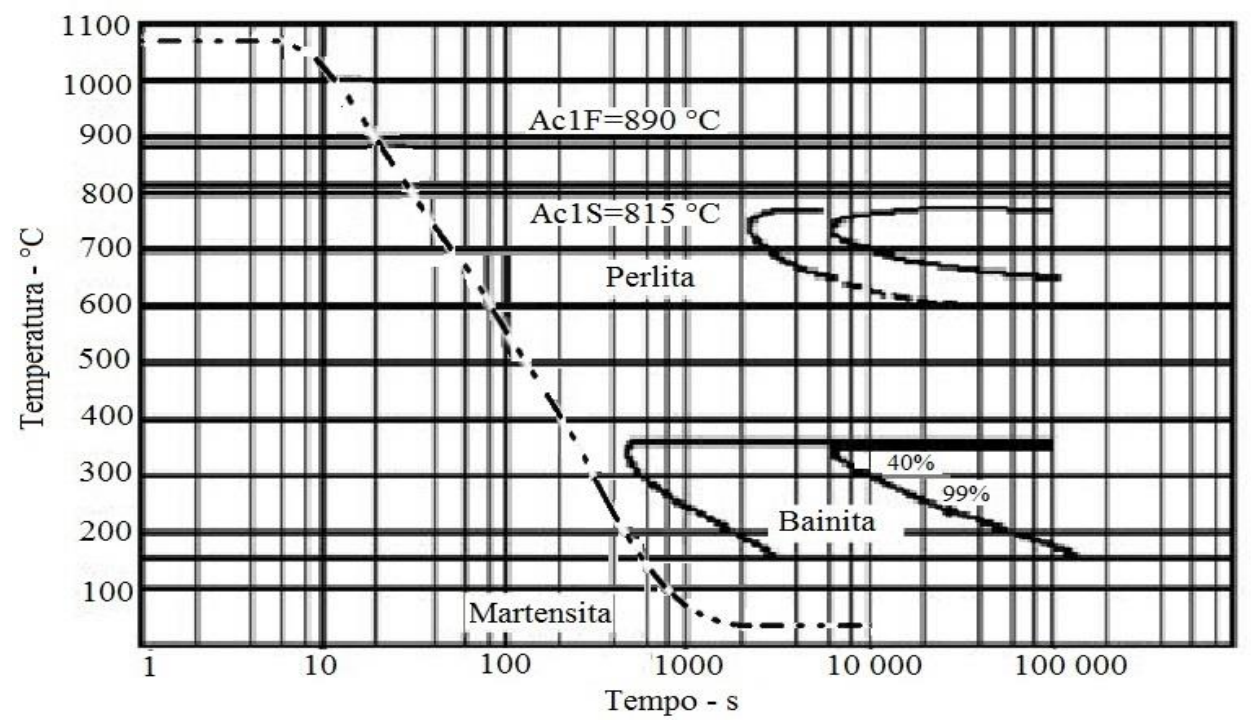

FIGURA 5.2 - Diagrama de transformação isotérmica (T.T.T.) para o aço rápido AISI M3:2 (Metal Ravne, 2016). 
Os diagramas C.C.T. desenvolvido por Vander Voort (1991) possuem uma forma de representação da linha de transformação de uma forma não usual.

"O eixo x não representa simplesmente a o tempo decorrido, portanto, as curvas de resfriamento não são sobrepostas sobre tais diagramas. Ao invés disto, o eixo x representa o tempo requerido para resfriar o material de $800{ }^{\circ} \mathrm{C}$ para $500{ }^{\circ} \mathrm{C}$, que está relacionada com a taxa de resfriamento. Devido a este tipo de representação gráfica, a transformação microestrutural é dada através de linhas verticais, ao invés da usual sobreposição das curvas de resfriamento sobre o gráfico. Além do mais, devido a essa construção de linhas verticais, é possível plotar a dureza para a temperatura ambiente (dureza Vickers com carga de $30 \mathrm{~kg}$ ) como função do tempo de resfriamento médio com uma curva simples" (Vander Voort, 1991).

A FIG. 5.3 mostra o diagrama C.C.T. para o aço rápido AISI M2 e a FIG. 5.4 mostra o diagrama C.C.T. para o aço ferramenta AISI D2 (Vander Voort, 1991).

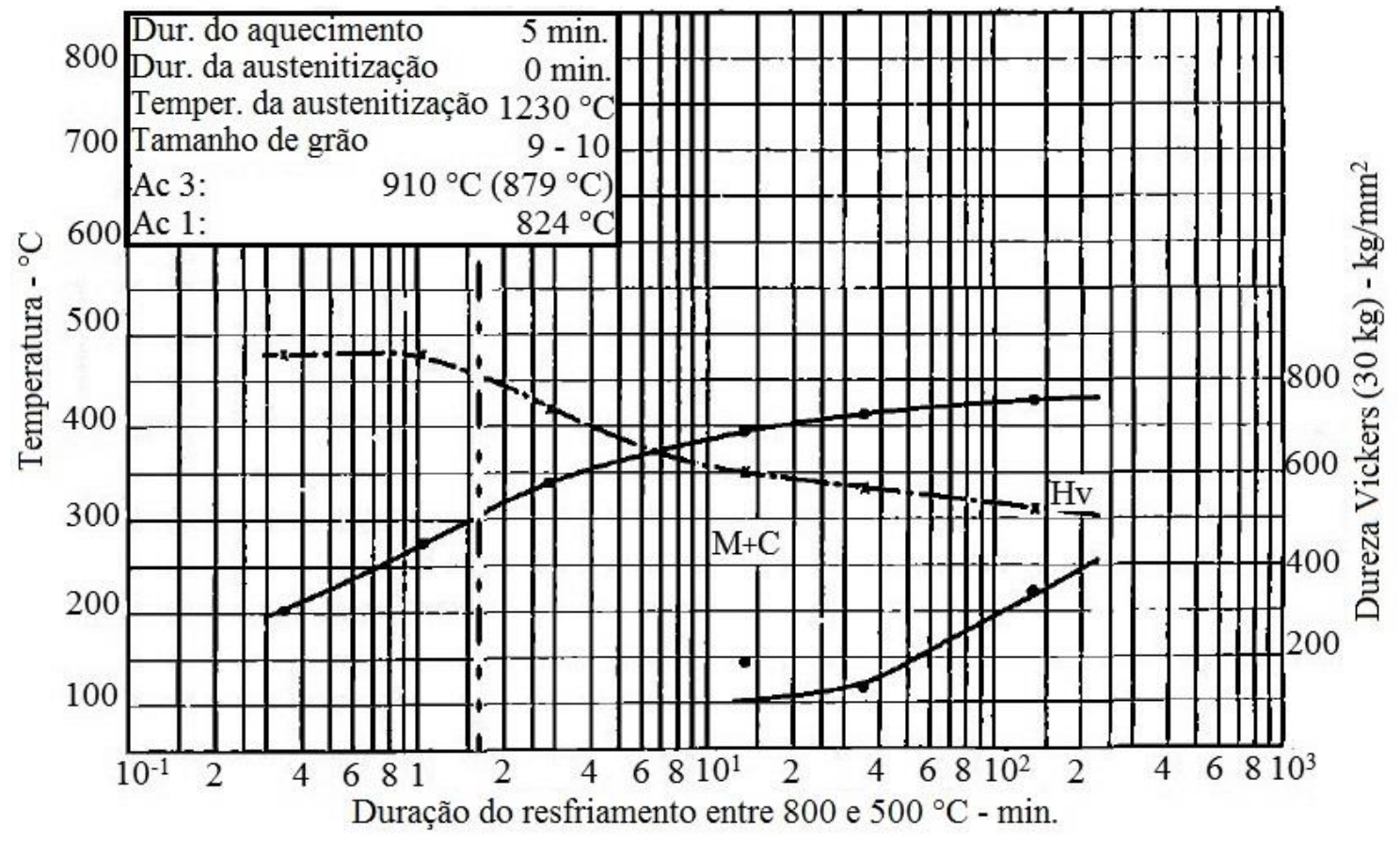

FIGURA 5.3 - Diagrama de transformação sob resfriamento contínuo (C.C.T.) para o aço rápido AISI M2 (Vander Voort, 1991). 


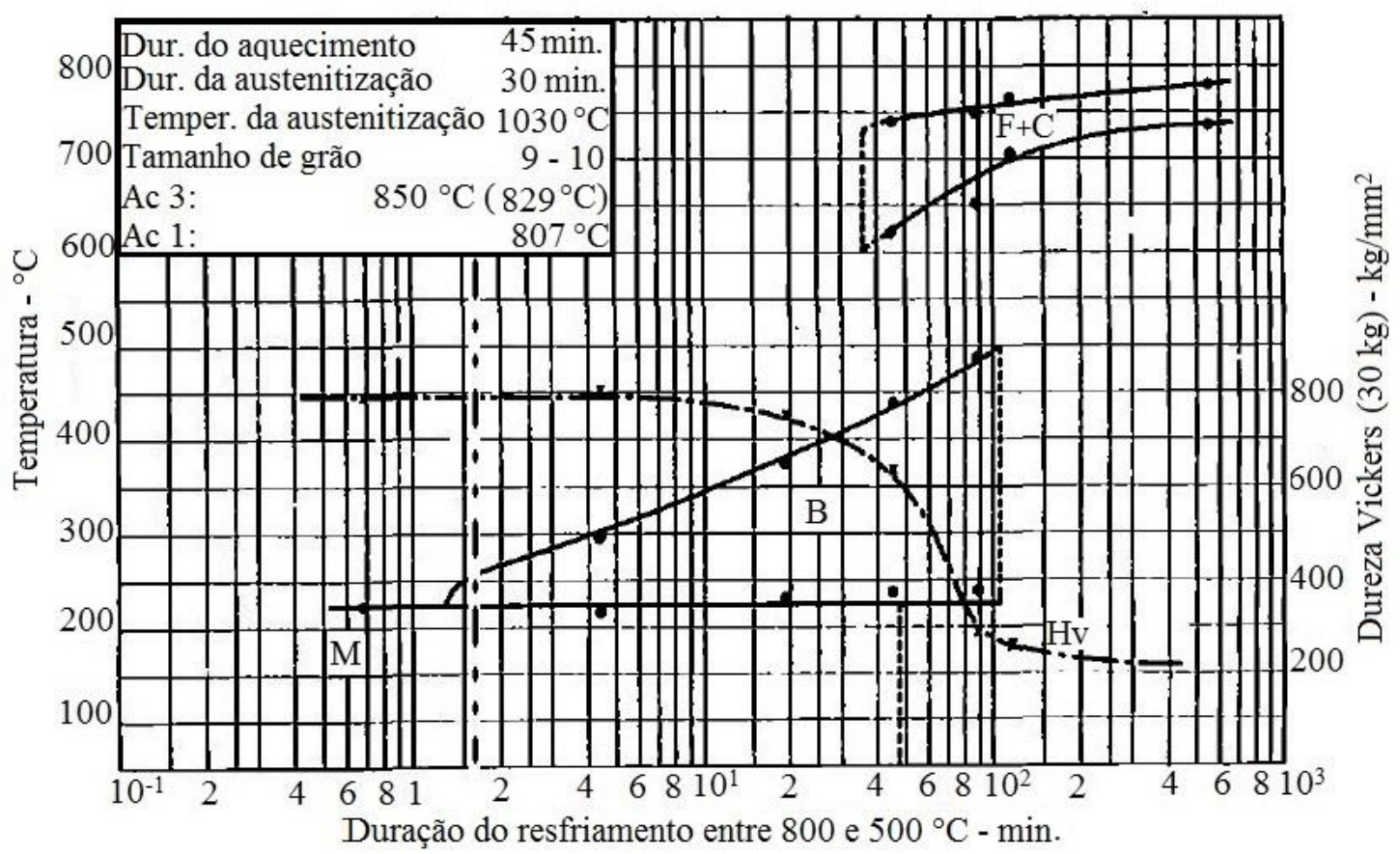

FIGURA 5.4 - Diagrama de transformação sob resfriamento contínuo (C.C.T.) para o aço rápido AISI D2 (Vander Voort, 1991).

Das curvas de resfriamento sobrepostas sobre os diagramas T.T.T. e C.C.T. mostrados anteriormente, pode-se inferir que a transformação da austenita do aço rápido AISI M3:2, aço rápido AISI M2 e aço ferramenta AISI D2 durante a têmpera ao óleo resultou somente na formação da martensita.

Além do mais, em cada mistura de pó encontraram-se microestruturas diferentes da prevista através dos referidos diagramas. Isto se deve ao fato da adição de outros elementos aos VSI, tais como os pós de ferro, sulfeto de manganês, carboneto de nióbio, grafite, entre outros, além dos pós propriamente ditos de aços rápidos e aço ferramenta.

\subsubsection{Caracterização microestrutural}

A avaliação da microestrutura dos VSI se deu por meio da MO e MEV. Almejando avaliar a homogeneidade dos componentes, estes foram analisados quanto a sua seção transversal e longitudinal. A FIG. 5.5 mostra como foi definida cada uma destas seções. 


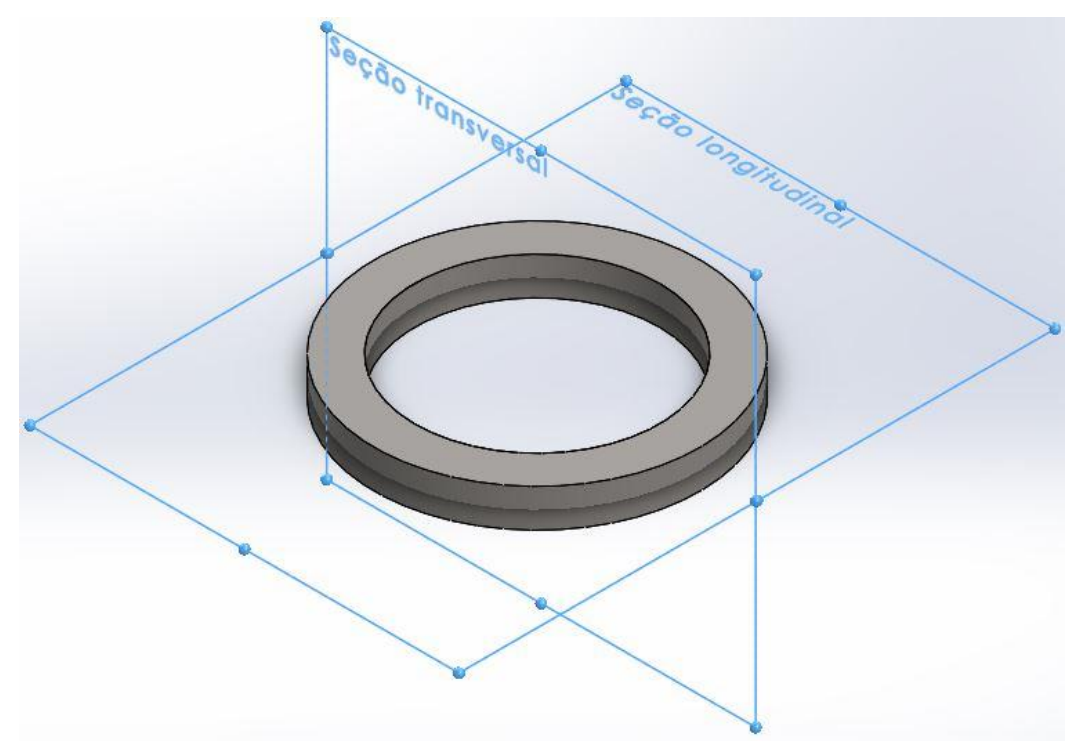

FIGURA 5.5 - Ilustração de onde os VSI foram seccionados para a avaliação da sua seção transversal e longitudinal.

A FIG. 5.6 e 5.7 mostram as micrografias ópticas das seções transversal e longitudinal, respectivamente, dos VSI obtidos com a Mistura 1. Esta mistura de pó é composta pelo aço rápido AISI M3:2 contendo tamanho mediano de partícula maior e maior porosidade, quando comparado ao aço rápido AISI M2 e aço ferramenta AISI D2 (ver TAB. 5.2). Estas duas propriedades tendem a diminuir as propriedades finais dos VSI obtidos com a Mistura 1, tais como dureza aparente, densidade aparente e resistência à ruptura radial.

No entanto, os componentes obtidos com esta mistura mostraram os melhores resultados entre todos os componentes obtidos, como é mostrado na TAB. 5.3. Isto pode ser justificado pelo fato do aço rápido utilizado na Mistura 1 possuir melhores propriedades mecânicas quando comparado aos outros pós de aço rápido e aço ferramenta estudados (Michael, 1981). Outros fatores como fina distribuição do cobre (Cu), a presença de grandes quantidades de martensita $(\mathrm{M})$, transformação tardia da austenita em outras fases devido ao tempo e temperatura insuficientes cedidos durante o tratamento térmico, e também a quantidade de carbono disponível (elemento adicionado na forma de grafite) sobre toda a microestrutura do VSI também colaboraram na melhoria das propriedades do componente. Esta combinação de tratamento térmico e mistura de pós contribuiu para os resultados excepcionais do componente quando comparado aos VSI obtidos com as outras duas misturas de pós, Mistura 2 e Mistura 3. 
Também é possível observar ilhas de ferrita $(\mathrm{Fe})$ quase não transformadas. Uma baixa quantidade de martensita contendo alta concentração de carbono $\left(\mathrm{M}^{\prime}\right)$ e perlita $(\mathrm{P})$ foram observadas, assim como a presença de sulfeto de manganês (MnS), carboneto de nióbio ( $\mathrm{NbC}$ ) e poros (regiões escuras).

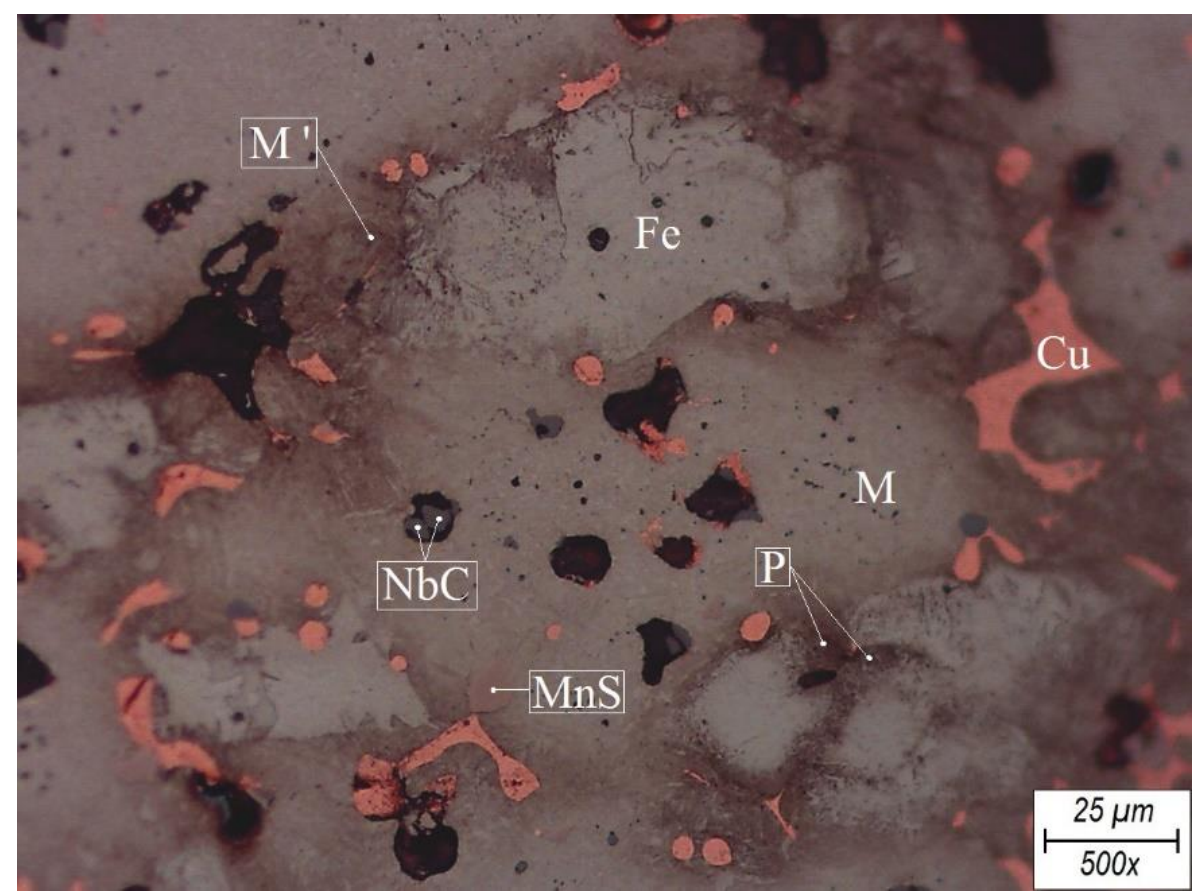

FIGURA 5.6 - Micrografia óptica da seção transversal do VSI obtido com a Mistura 1 (AISI M3:2) temperado ao ar e duplamente revenido a $600{ }^{\circ} \mathrm{C}$. Ataque: Nital $3 \%$ por $5 \mathrm{~s}$.

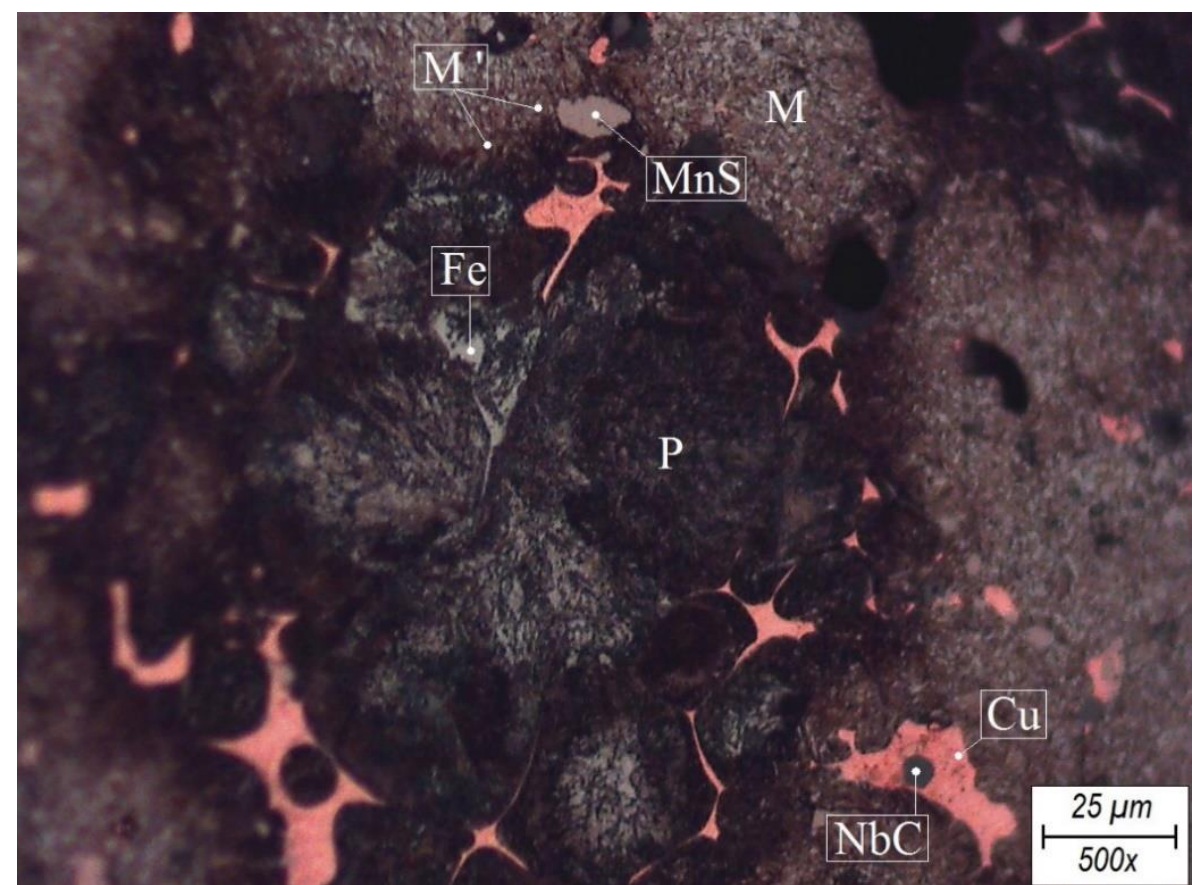

FIGURA 5.7 - Micrografia óptica da seção longitudinal do VSI obtido com a Mistura 1 (AISI M3:2) temperado ao ar e duplamente revenido a $600{ }^{\circ} \mathrm{C}$. Ataque: Nital $3 \%$ por $5 \mathrm{~s}$. 
Conforme mostrado na FIG. 5.8 (seção transversal) e a análise química indicada na TAB. 5.4, há uma alta concentração de cobre presente na Mistura 2, o que torna a microestrutura do componente mais dúctil. Analisando-se a FIG. 5.9 (seção longitudinal), não se observa essa quantidade maior de cobre, podendo ser justificado devido à região específica de análise.

Por outro lado, a menor distribuição do tamanho de partículas do aço rápido AISI M2 em relação ao aço rápido AISI M3:2 e aço ferramenta AISI D2 (ver $T A B$. 5.2), em conjunto com a formação de grandes quantidades de regiões martensíticas e outras áreas menores contendo perlita, bainita (B) e ferrita, desempenharam papel fundamental nos bons resultados dos VSI obtidos com a Mistura 2 quando comparadas as propriedades dos componentes obtidos com as outras misturas de pós.

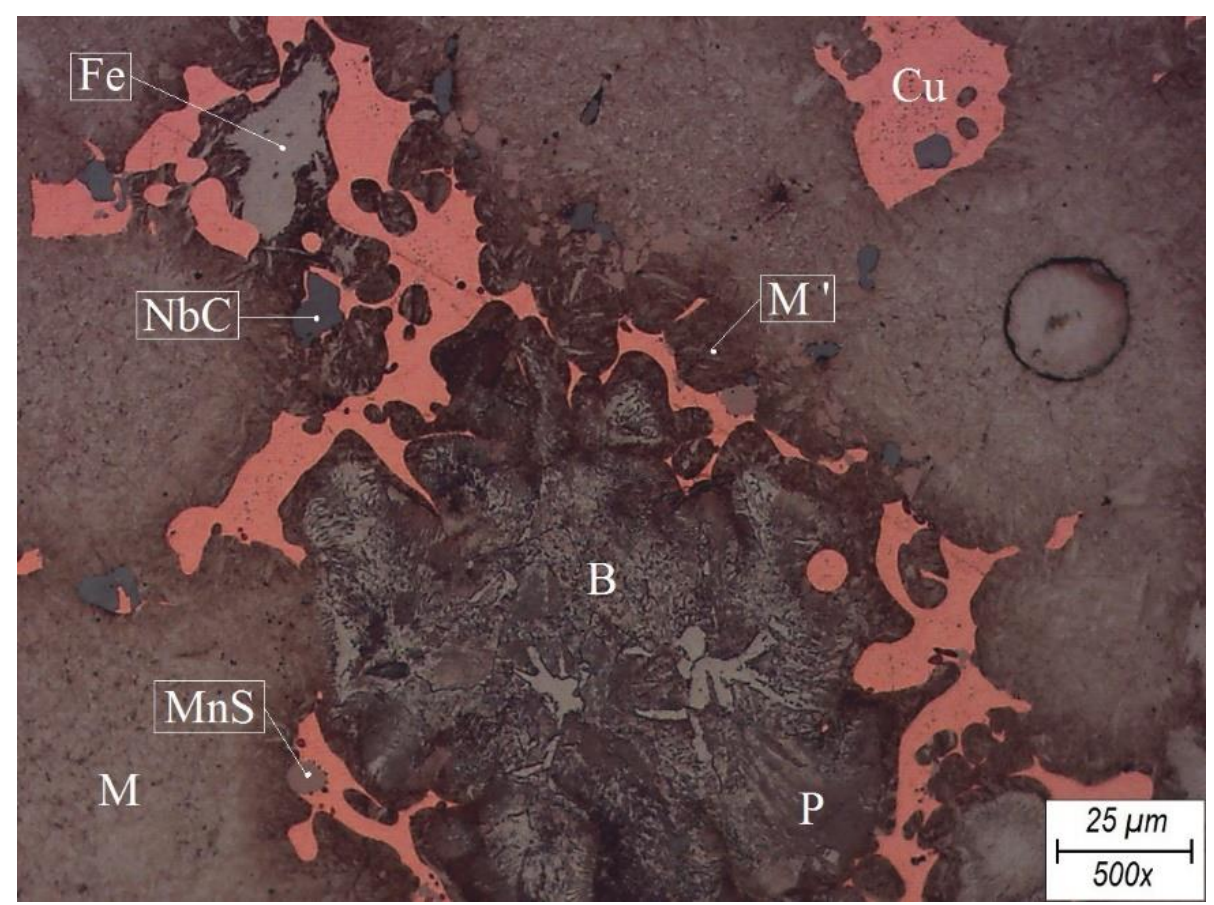

FIGURA 5.8 - Micrografia óptica da seção transversal do VSI obtido com a Mistura 2 (AISI M2) temperado ao ar e duplamente revenido a $600{ }^{\circ} \mathrm{C}$. Ataque: Nital $3 \%$ por $5 \mathrm{~s}$. 


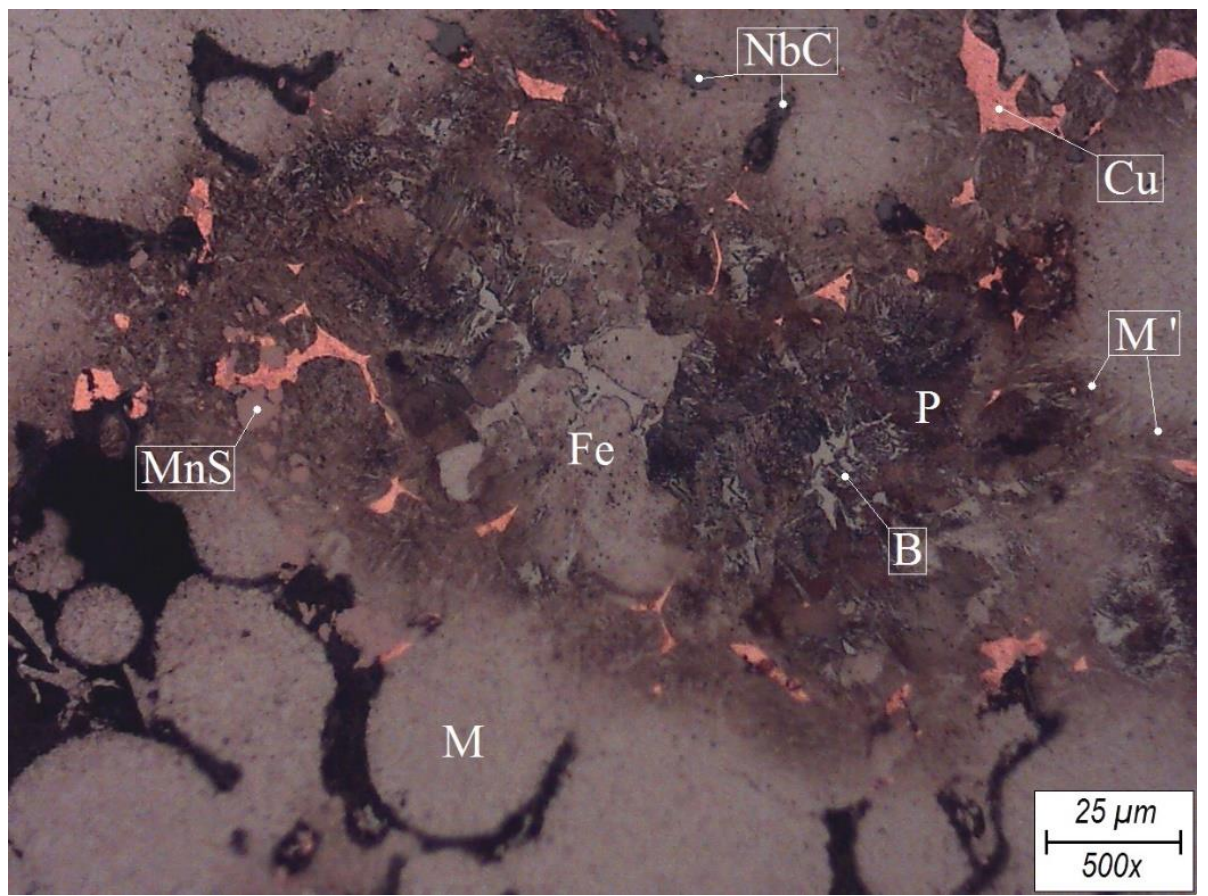

FIGURA 5.9 - Micrografia óptica da seção longitudinal do VSI obtido com a Mistura 2 (AISI M2) temperado ao ar e duplamente revenido a $600{ }^{\circ} \mathrm{C}$. Ataque: Nital $3 \%$ por $5 \mathrm{~s}$.

É possível observar na FIG. 5.10 (seção transversal) que o VSI obtido com a Mistura 3 (AISI D2) possui a maior difusão entre fases, devido a uma transformação quase que total da austenita em perlita quando comparada com as outras misturas de pós. Esta alta difusão e propriedades mecânicas inferiores do aço ferramenta utilizado na Mistura 3 (Michael, 1981) influenciaram de uma maneira negativa em relação as propriedades do componente.

No entanto, a formação de regiões bainíticas como previsto no diagrama C.C.T. (FIG. 5.4), e melhor observada na FIG. 5.11 (seção longitudinal), maior densidade aparente entre todas as misturas (ver TAB. 5.3) e a fina distribuição do cobre contribuíram de uma forma positiva nas propriedades físicas e mecânicas dos VSI obtidos para tal mistura. 


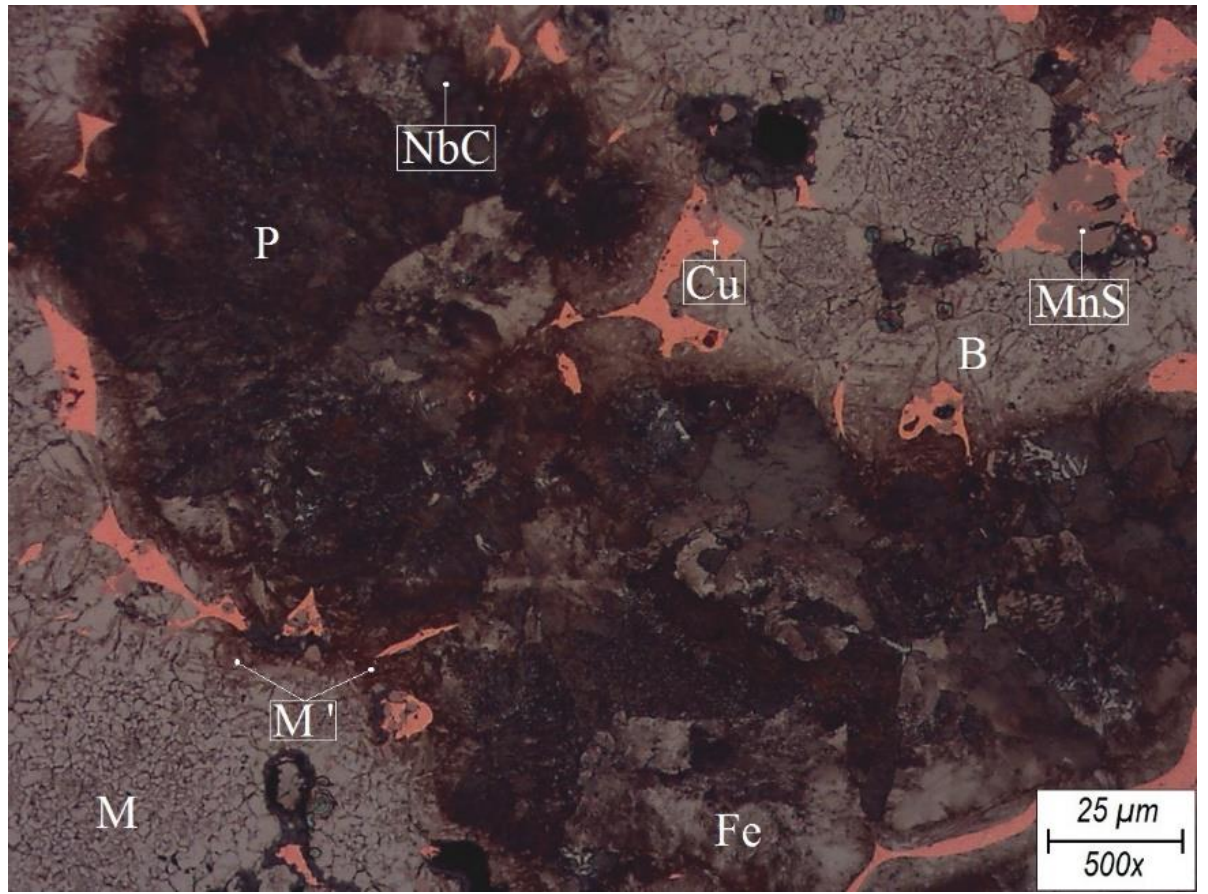

FIGURA 5.10 - Micrografia óptica da seção transversal do VSI obtido com a Mistura 3 (AISI D2) temperado ao ar e duplamente revenido a $500{ }^{\circ} \mathrm{C}$. Ataque: Nital $3 \%$ por $5 \mathrm{~s}$.

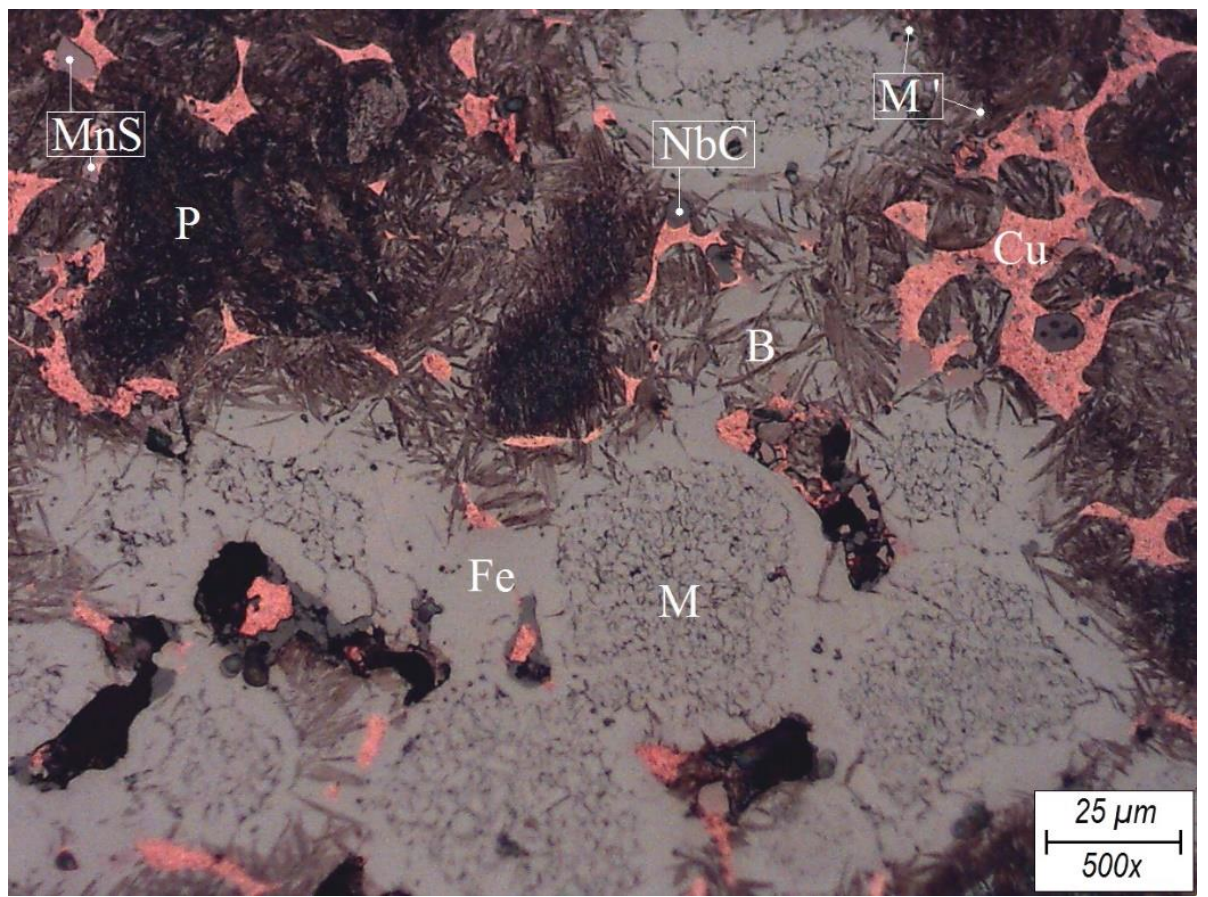

FIGURA 5.11 - Micrografia óptica da seção longitudinal do VSI obtido com a Mistura 3 (AISI D2) temperado ao ar e duplamente revenido a $500{ }^{\circ} \mathrm{C}$. Ataque: Nital $3 \%$ por $5 \mathrm{~s}$.

As figuras de número FIG. 5.12 a FIG. 5.17 apresentam as micrografias eletrônicas obtidas por MEV. Essas imagens mostram a distribuição das diferentes fases presentes nas três misturas de pós diferentes. Tal análise foi feita no MEV no 
modo de detecção de elétrons retroespalhados (BSE) com o suporte da espectrometria por energia dispersiva (EDS). Devido ao excesso de ataque, fases como bainita $(B)$, perlita $(P)$, ferrita $(F e)$, martensita $(M)$ e martensita contendo altas concentrações de carbono (M') pareceram corroídas.

Outros elementos como o carboneto de nióbio $(\mathrm{NbC})$ e sulfeto de manganês (MnS) podem ser distinguidos sobre a microestrutura dos VSI. Em todas as misturas de pós, toda a martensita presente resultou da transformação da austenita dos aços rápidos e aço ferramenta como indicado nos diagramas de transformação de fase (FIG. 5.2 a FIG. 5.4), i.e., não há formação de martensita originária do pó de ferro mesmo havendo a adição de outros elementos como o grafite.

Na FIG. 5.12 (seção transversal) da Mistura 1 é possível observar a formação de placas de ferrita e também a presença de poros nas regiões de contornos dos grãos (região preta). A observação geral da microestrutura mostrou que esta é bastante homogênea sobre toda a região analisada do VSI em relação às outras misturas. Já para a FIG. 5.13 (seção longitudinal), há a definição bastante evidente das regiões que contém o pó de aço rápido (AISI M3:2) e pó de ferro. Isto provavelmente está atrelado a uma região em particular da amostra.

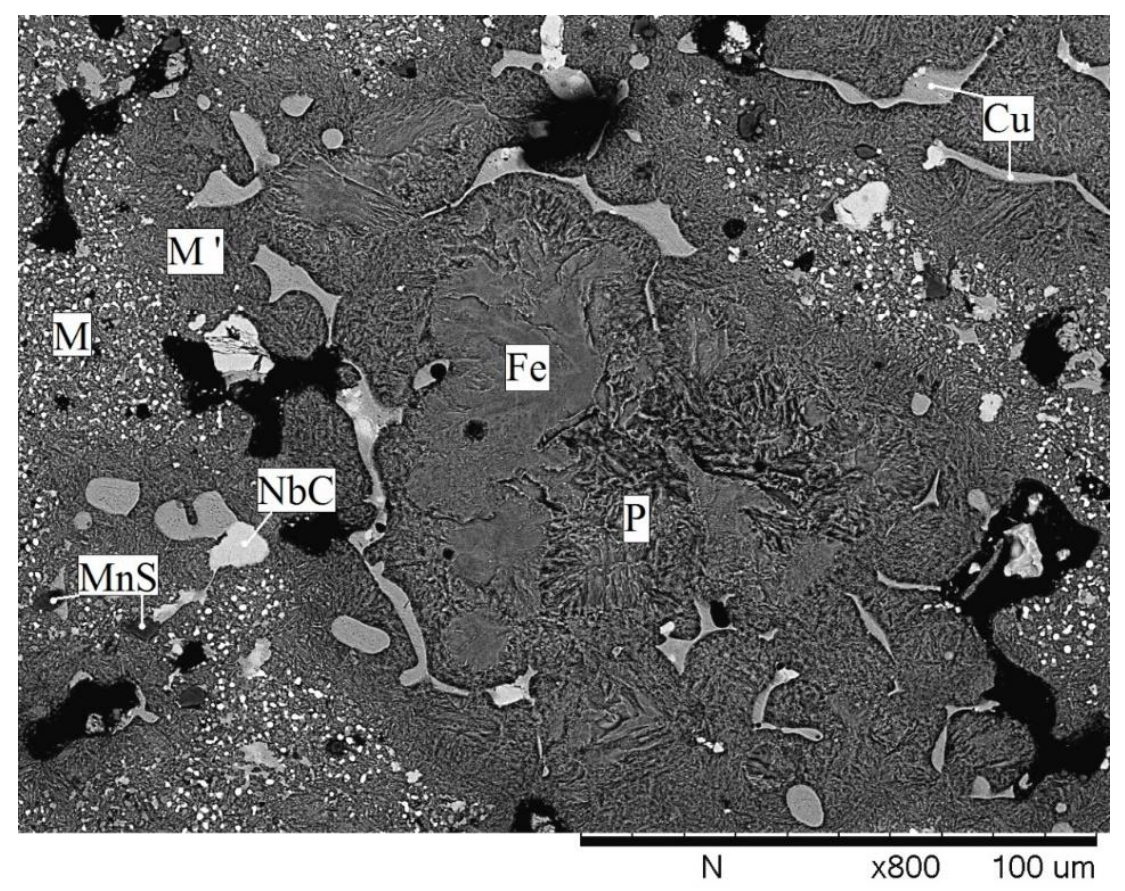

FIGURA 5.12 - Micrografia obtida por MEV com identificação de elementos por EDS da seção transversal do VSI obtido com a Mistura 1, após temperado ao ar e duplamente revenido a $600{ }^{\circ} \mathrm{C}$. Ataque: Nital $3 \%$ por $50 \mathrm{~s}$. 


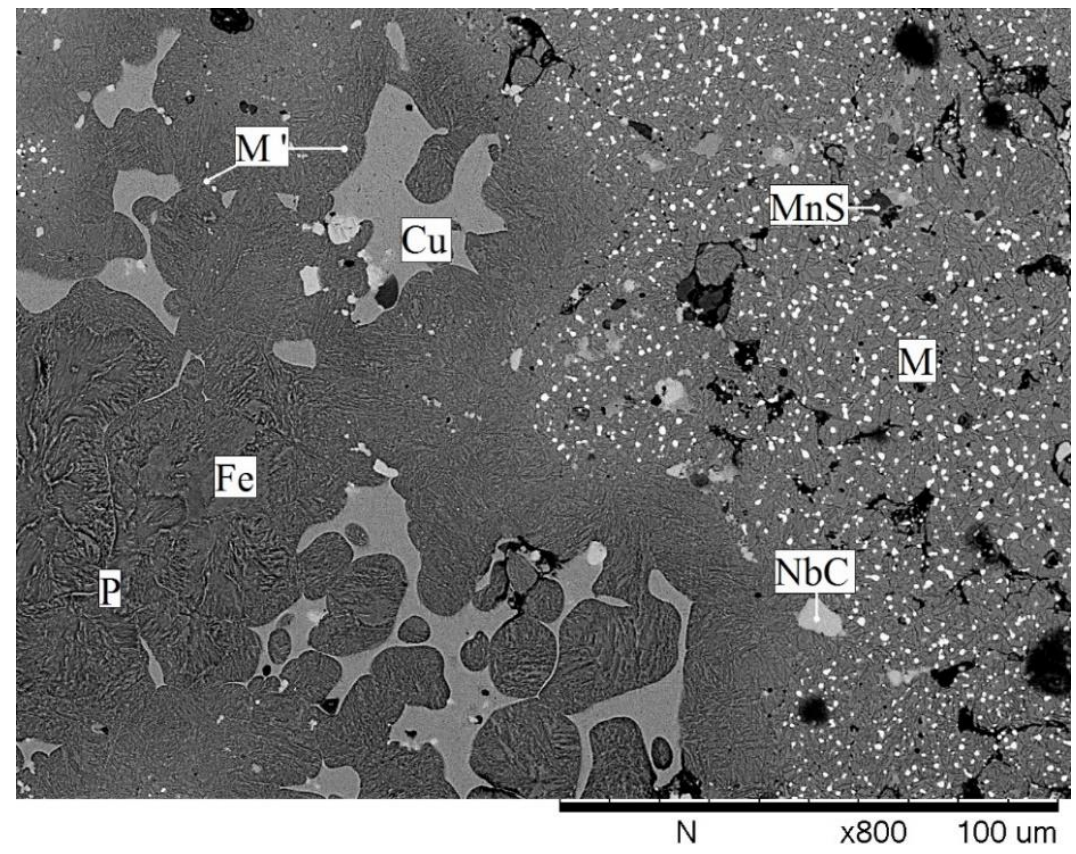

FIGURA 5.13 - Micrografia obtida por MEV com identificação de elementos por EDS da seção longitudinal do VSI obtido com a Mistura 1, após temperado ao ar e duplamente revenido a $600{ }^{\circ} \mathrm{C}$. Ataque: Nital $3 \%$ por $50 \mathrm{~s}$.

Para a Mistura 2, na FIG. 5.14 (seção transversal) pode-se observar a grande presença do aço rápido (AISI M2) e do cobre $(\mathrm{Cu})$, este último estando em acordo com os dados apresentados na TAB. 5.2, pois a Mistura 2 é a que apresenta a maior quantidade de tal elemento.

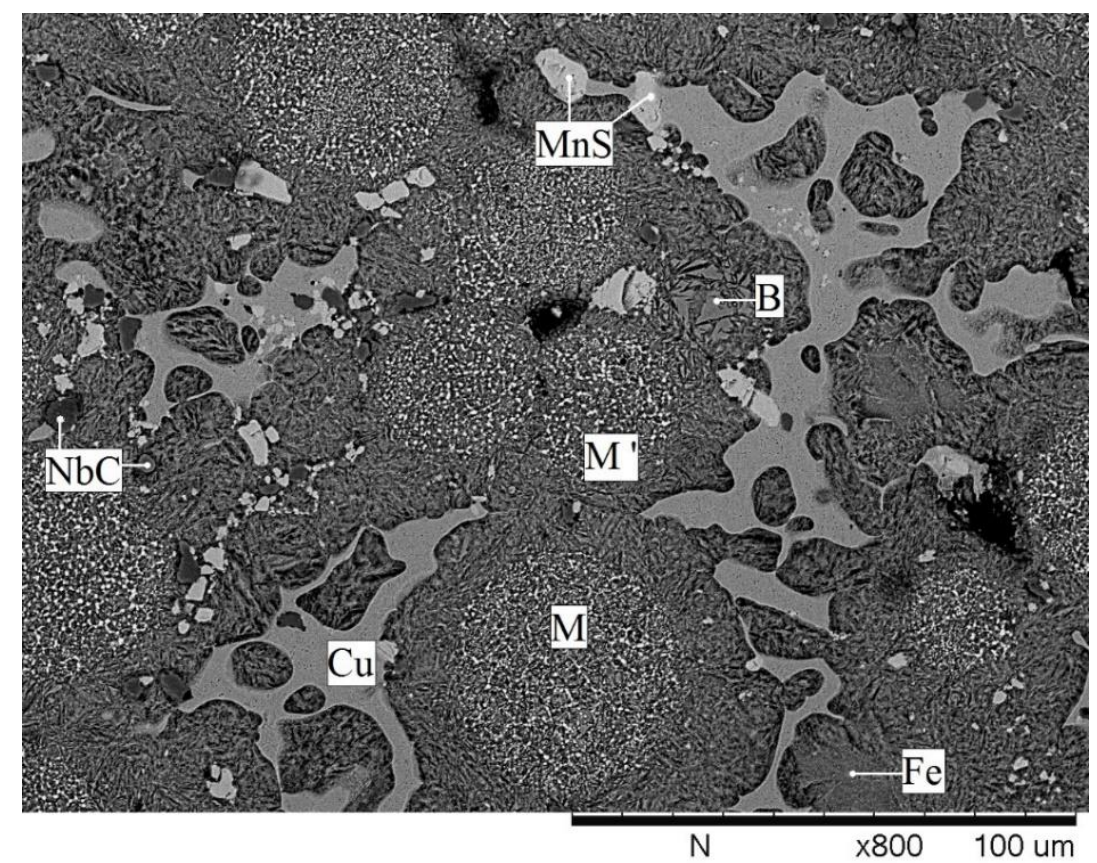

FIGURA 5.14 - Micrografia obtida por MEV com identificação de elementos por EDS da seção transversal do VSI obtido com a Mistura 2, após temperado ao ar e duplamente revenido a $600{ }^{\circ} \mathrm{C}$. Ataque: Nital $3 \%$ por $50 \mathrm{~s}$. 
Porém, observando-se a FIG. 5.15 (seção longitudinal) para a Mistura 2, há uma aparente redução na quantidade cobre $(\mathrm{Cu})$, se opondo aos valores apresentados na TAB. 5.2, pois esta mostra que tal mistura possui a maior concentração de cobre, sendo 15,04\% contra 12,54\% (Mistura 1) e 11,79\% (Mistura 3). Tal ocorrência pode ser atribuída a uma região em particular da amostra. Também, pode-se observar a formação de uma camada de óxido de aparência escura e com trincas, podendo estar atrelada a oxidação da amostra entre o intervalo de preparação da amostra e análise por meio do MEV.

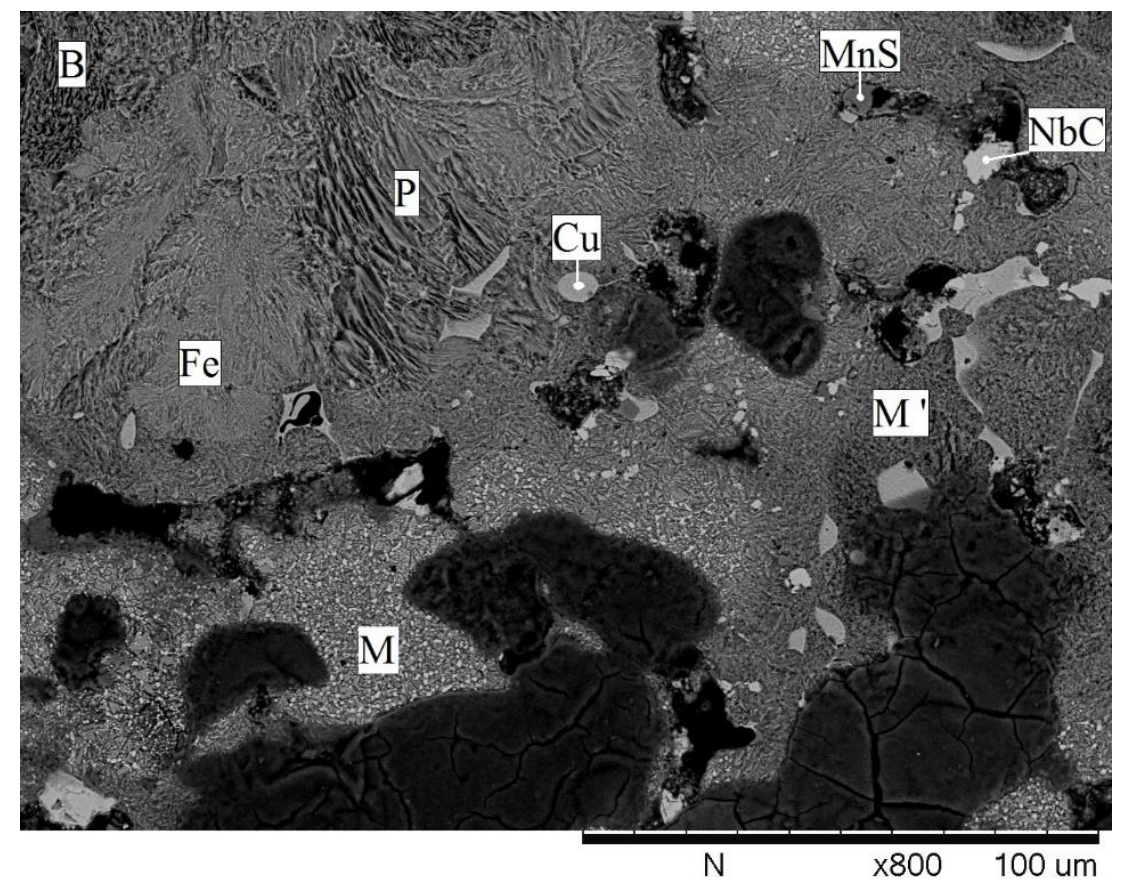

FIGURA 5.15 - Micrografia obtida por MEV com identificação de elementos por EDS da seção longitudinal do VSI obtido com a Mistura 2, após temperado ao ar e duplamente revenido a $600{ }^{\circ} \mathrm{C}$. Ataque: Nital $3 \%$ por $50 \mathrm{~s}$.

Uma formação bainítica no aço ferramenta AISI D2 (Mistura 3) pôde ser observada por meio da FIG. 5.16 (seção transversal) nos contornos de grão. Esta mesma fase é mais realçada na FIG. 5.17 (seção longitudinal). A formação desta fase pode ser prevista de acordo com a plotagem da curva de resfriamento do tratamento térmico sobre o diagrama C.C.T. para a Mistura 3 (ver FIG. 5.4). 


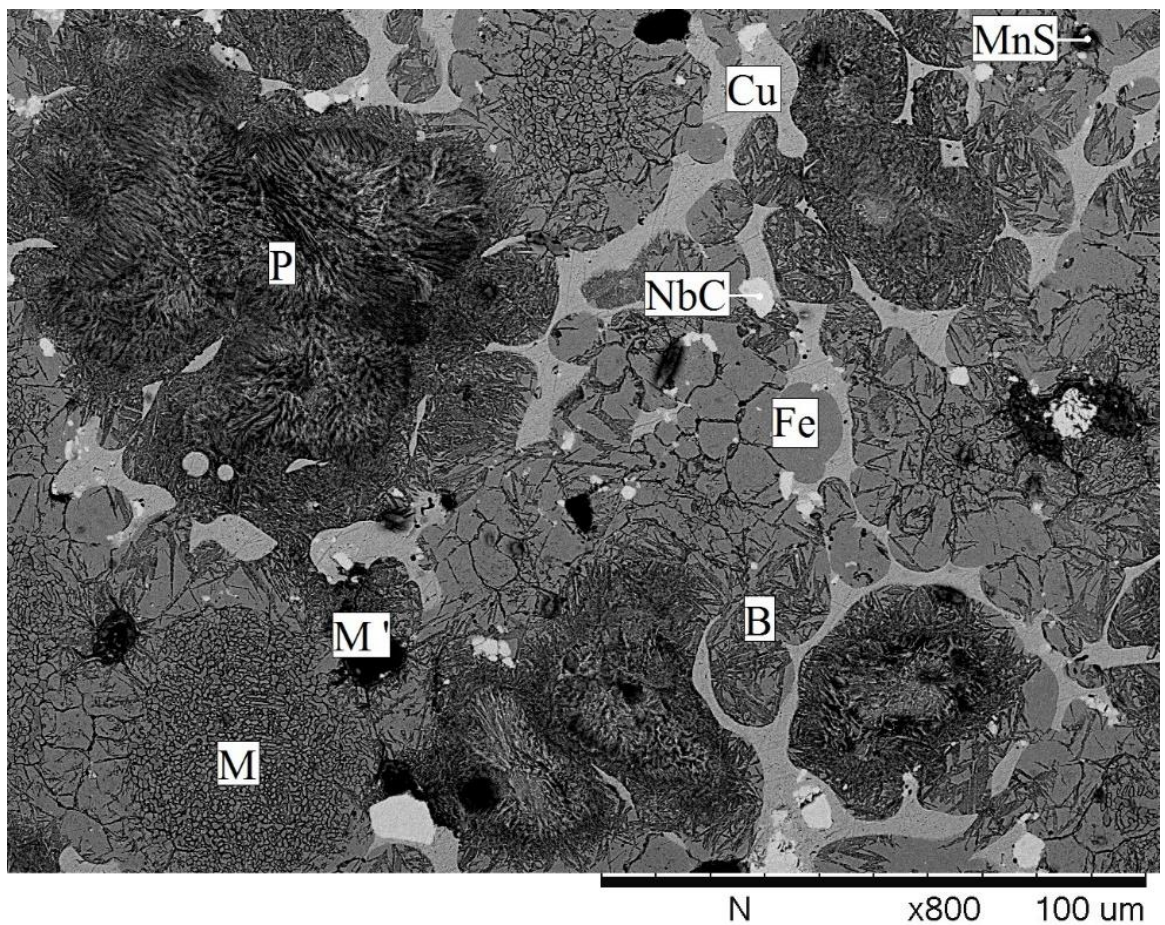

FIGURA 5.16 - Micrografia obtida por MEV com identificação de elementos por EDS da seção transversal do VSI obtido com a Mistura 3, após tempera ao ar e revenido duplo a $500{ }^{\circ} \mathrm{C}$. Ataque: Nital $3 \%$ por $50 \mathrm{~s}$.

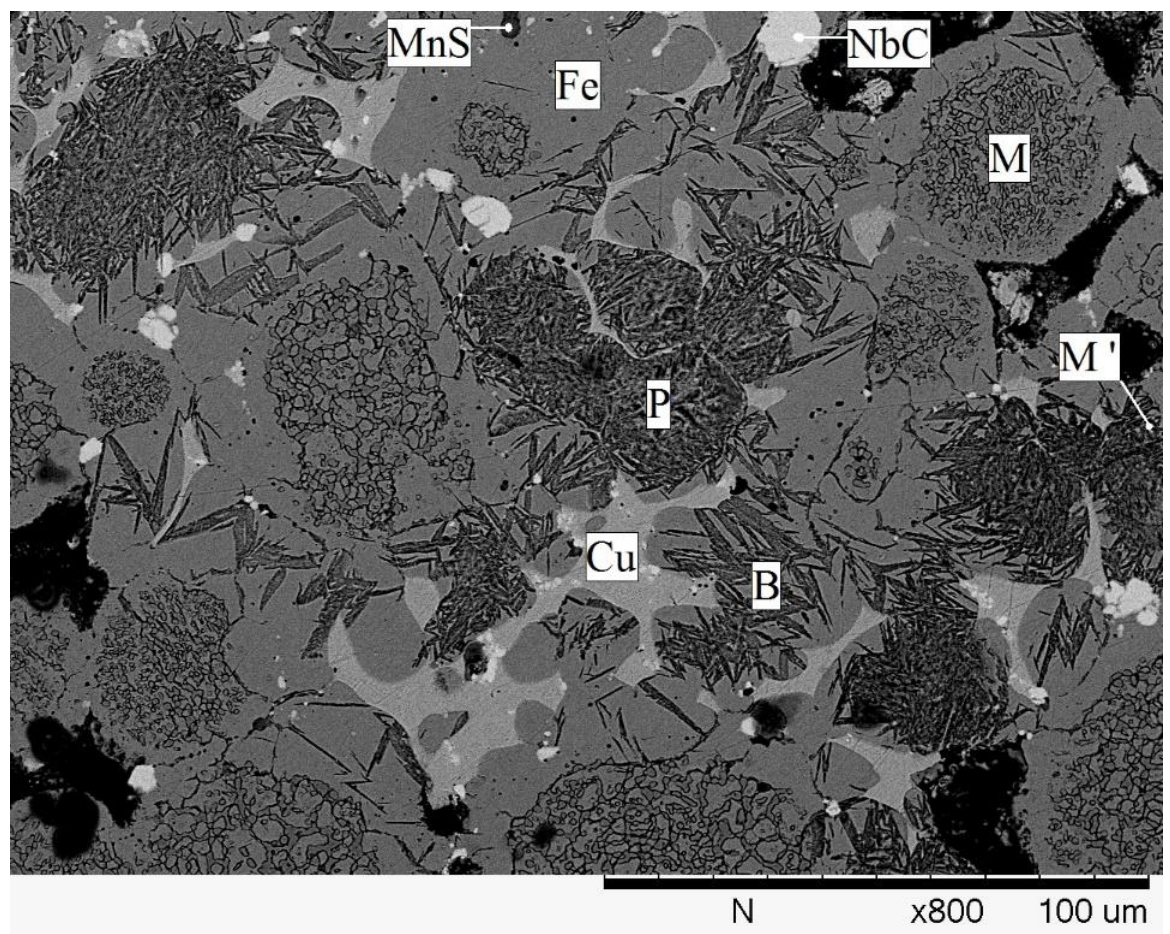

FIGURA 5.17 - Micrografia obtida por MEV com identificação de elementos por EDS da seção longitudinal do VSI obtido com a Mistura 3, após tempera ao ar e revenido duplo a $500{ }^{\circ} \mathrm{C}$. Ataque: Nital $3 \%$ por $50 \mathrm{~s}$. 


\subsection{Têmpera ao óleo}

\subsubsection{Propriedades físicas e mecânicas}

Para os VSI apenas como sinterizados e também temperados ao óleo e duplamente revenido em sete temperaturas diferentes, realizou-se a medição dos valores de dureza aparente conforme mostra a FIG. 5.18.

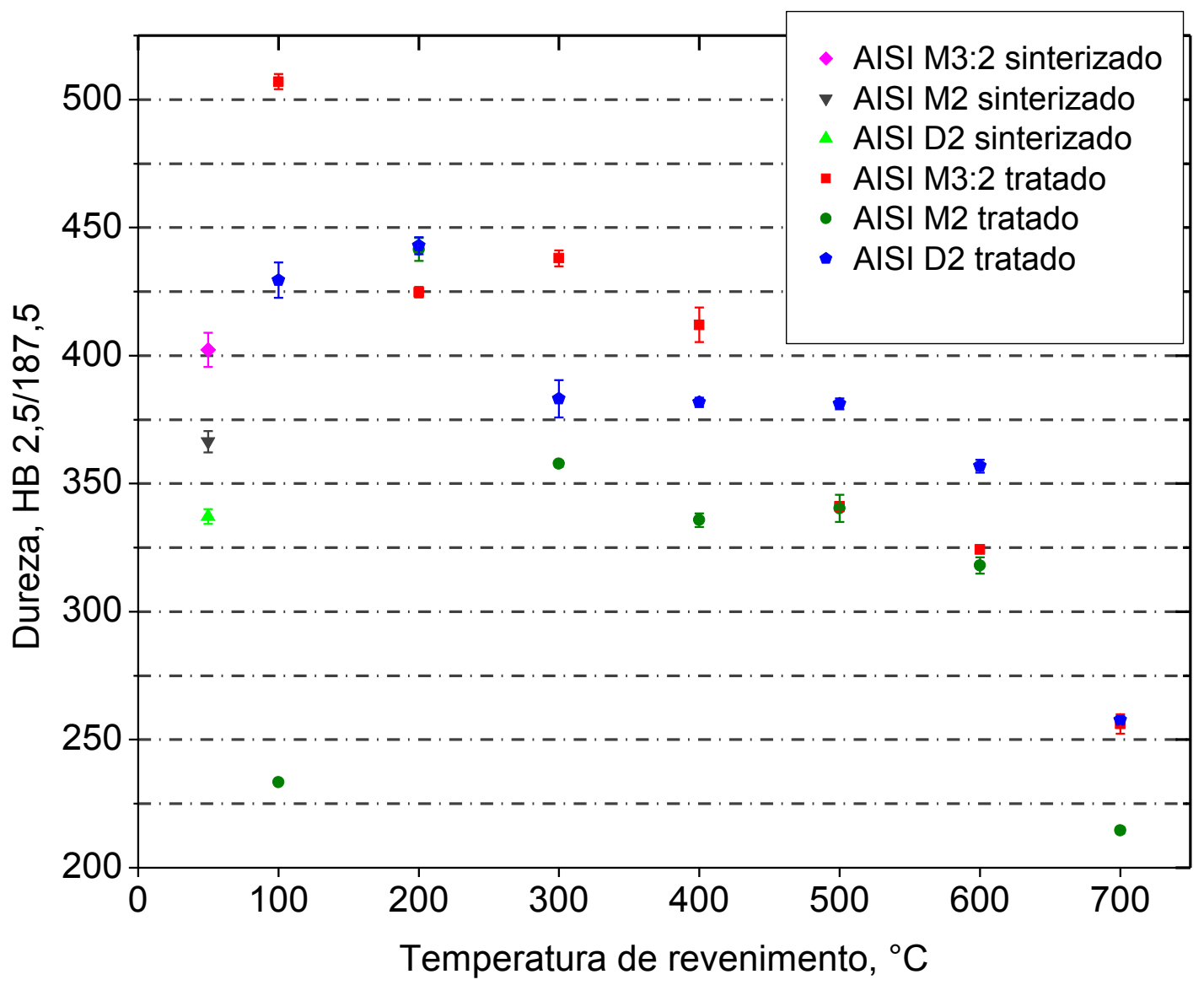

FIGURA 5.18 - Variação da dureza Brinell (HB 2,5 / 187,5) nos VSI apenas como sinterizados e também nos componentes temperados ao óleo e duplamente revenido em sete temperaturas diferentes.

É notavelmente destacada a variação positiva da dureza aparente para todos os VSI temperados ao óleo e duplamente revenido em comparação ao mesmo tipo de gráfico para os componentes temperados ao ar e duplamente revenido (FIG. 5.1).

A mudança nos valores de dureza aparente dos VSI após terem sido submetidos aos tratamentos térmicos de têmpera ao óleo e duplo revenimento em sete temperaturas diferentes, pode ser melhor compreendido por observação da TAB. 5.7. 
TABELA 5.7 - Variação da dureza Brinell (HB 2,5 / 187,5) nos VSI apenas como sinterizado e também nos componentes temperados ao óleo e duplamente revenido em sete temperaturas diferentes.

\begin{tabular}{ccccccccc}
\hline & & \multicolumn{7}{c}{ Temperatura de duplo revenimento $\left({ }^{\circ} \mathrm{C}\right)$} \\
\cline { 3 - 8 } Mistura & Sinterizado & 100 & 200 & 300 & 400 & 500 & 600 & 700 \\
\hline \multirow{2}{*}{ Mistura 1 } & 402 & 507 & 425 & 438 & 412 & 341 & 324 & 256 \\
& \pm 7 & \pm 3 & \pm 2 & \pm 3 & \pm 7 & \pm 2 & \pm 2 & \pm 4 \\
Mistura 2 & 366 & 233 & 441 & 358 & 336 & 340 & 318 & 215 \\
& \pm 4 & \pm 1 & \pm 4 & \pm 1 & \pm 3 & \pm 5 & \pm 3 & \pm 1 \\
Mistura 3 & 337 & 429 & 443 & 383 & 381 & 381 & 357 & 258 \\
& \pm 3 & \pm 7 & \pm 3 & \pm 7 & \pm 2 & \pm 2 & \pm 2 & \pm 1 \\
\hline
\end{tabular}

Realizou-se a comparação entre os diferentes valores de dureza aparente em consequência dos tratamentos térmicos de têmpera ao ar e têmpera ao óleo. Para tal, foi considerado o valor de dureza aparente média, que considera a média entre todas as amostras tratadas termicamente.

No primeiro caso (ver TAB. 5.2), é possível notar que os VSI obtidos com a Mistura 3 (AISI D2) obtiveram valores de dureza aparente abaixo da faixa recomendada pelos fabricantes de motores automotivos, sendo esta de $370 \mathrm{HB} \mathrm{e}$ 410 HB $(2,5$ / 187,5). Já as medidas de dureza aparente média para os componentes obtidos com a Mistura 1 e Mistura 2 ficaram acima deste valor de referência.

No segundo caso (ver TAB. 5.7), pode-se observar que todos os componentes obtidos com as três misturas de pós diferentes ficaram acima do valor médio de referência. A Mistura 3 foi a que se destacou por apresentar a melhor resposta aos diferentes tratamentos térmicos, pois passou do $\mathrm{VSI}$ com pior valor de dureza aparente em relação à têmpera ao ar para o componente com melhor resposta entre as todas as misturas de pós diferentes após a têmpera ao óleo.

Apesar da ótima resposta dos VSI ao tratamento térmico de têmpera ao óleo e duplo revenimento, o estudo centrou-se nos VS/ obtidos com as três misturas de pós diferentes após estes terem sido tratados em uma única faixa de temperatura. Esta faixa de temperatura foi escolhida em função dos valores de referência de dureza aparente estipulado pelos fabricantes de tais componentes.

Então, os valores de dureza aparente foram de $412 \pm 7$ para a Mistura 1 (AISI M3:2) duplamente revenida a $400{ }^{\circ} \mathrm{C}$. Já para a Mistura 2 e Mistura 3, os valores de dureza aparente foram de $358 \pm 1$ e $383 \pm 7$, respectivamente, sendo 
que estas foram duplamente revenida a $300{ }^{\circ} \mathrm{C}$. Portanto, todos os resultados e discussão a seguir se basearam em cada uma das misturas anteriores com seus respectivos tratamentos térmicos.

Assim como o controle da dureza aparente dos VSI é importante, avaliar as suas propriedades físicas de densidade aparente e resistência à ruptura radial também se faz necessário. Os valores obtidos durante a avaliação das principais propriedades físicas e mecânicas dos VSI que melhor responderam aos tratamentos térmicos de têmpera ao óleo e duplo revenimento é mostrado na TAB. 5.8 .

TABELA 5.8 - Principais propriedades físicas e mecânicas dos VSI obtidos com a Mistura 1 (AISI M3:2), Mistura 2 (AISI M2) e Mistura 3 (AISI D2), temperados ao óleo e duplamente revenido a $400^{\circ} \mathrm{C}, 300^{\circ} \mathrm{C}$ e $300^{\circ} \mathrm{C}$, respectivamente.

\begin{tabular}{cccc}
\hline Mistura & $\begin{array}{c}\text { Dureza aparente } \\
\text { HB 2,5 / 187,5 }\end{array}$ & $\begin{array}{c}\text { Densidade aparente } \\
\text { g.cm }\end{array}$ & $\begin{array}{c}\text { Resistência à ruptura radial } \\
\mathrm{MPa}\end{array}$ \\
\hline Mistura 1 & $412 \pm 7$ & $7,2 \pm 0,3$ & $1.165 \pm 23$ \\
Mistura 2 & $358 \pm 1$ & $7,4 \pm 0,3$ & $984 \pm 125$ \\
Mistura 3 & $383 \pm 2$ & $7,3 \pm 0,1$ & $1.111 \pm 30$ \\
\hline
\end{tabular}

No trabalho desenvolvido por Jesus Filho (2006) avaliou-se VSI obtidos com o pó de aço rápido AISI M3:2. Foi feito o estudo minucioso dos componentes apenas como sinterizados. Os valores de densidade aparente e resistência à ruptura radial medidos por Jesus Filho foram de 7,33 g.cm ${ }^{-3}$ e $1.268 \mathrm{MPa}$, respectivamente. Tais valores foram maiores em relação aos encontrados para a Mistura 1 (AISI M3:2), tendo sido de 7,2 g.cm e $1.165 \mathrm{MPa}$, respectivamente. Porém, os valores de dureza aparente medidos por Jesus Filho, $380 \pm 25 \mathrm{HB}$, foram menores do que os valores encontrados no presente trabalho, $412 \pm 7 \mathrm{HB}$.

Santos et al. (2014 e 2016) obteve em seu estudo VSI com as mesmas misturas de pós utilizadas ao longo deste trabalho. Somente componentes apenas como sinterizados foram analisados em tal estudo. Os valores de densidades aparentes medidos por Santos ficaram próximos dos obtidos para a Mistura 2 e Mistura 3, sendo de 7,4 g. $\mathrm{cm}^{-3}$ e $7,3 \mathrm{~g} \cdot \mathrm{cm}^{-3}$, respectivamente. Os valores de dureza aparente obtidos por Santos, $345 \pm 21 \mathrm{HB}$ e $325 \pm 22 \mathrm{HB}$, foram menores do que as medidas encontradas no presente trabalho para a Mistura 2 e Mistura 3, $358 \pm$ 1 e $383 \pm 2 \mathrm{HB}$, respectivamente. 
Santos obteve valores de resistência à ruptura radial de $595 \pm 48 \mathrm{MPa} e$ $945 \pm 81 \mathrm{MPa}$, que foram maiores do que os encontrados neste trabalho, $984 \pm 125$ $\mathrm{MPa}$ e $1.111 \pm 30 \mathrm{MPa}$, para a Mistura 2 e Mistura 3, respectivamente. Como já mencionado, não há algum valor mínimo de referência para tal propriedade, o componente somente precisa suportar a etapa de montagem no cabeçote do motor.

\subsubsection{Diagramas de transformação de fase}

Do mesmo modo que na têmpera ao ar, o tratamento térmico de têmpera ao óleo consiste em resfriar o material a ser tratado continuamente, possibilitando assim o uso de diagramas de transformação de fase para prever as transformações microestruturais resultantes do tratamento térmico.

Durante a têmpera ao óleo, todos os VSI foram colocados no mesmo recipiente e tratados termicamente de uma só vez, desta maneira garantindo a mesma taxa de resfriamento em todos os componentes tratados. A taxa média de resfriamento medida durante o ciclo de têmpera ao óleo foi obtida com a utilização de termopares do tipo $\mathrm{k}$ afixados a amostra e ao sistema de aquisição de dados. A taxa média de resfriamento obtida para o referido tratamento térmico foi de $27^{\circ} \mathrm{C} / \mathrm{s}$.

Além da medida da taxa de resfriamento, o sistema de aquisição de dados possibilitou a obtenção da curva de resfriamento, sendo que esta foi posteriormente plotada sobre os diagramas de transformações de fases. Tais curvas foram sobrepostas com o formato de linha traço-dois pontos.

Como detalhado no item 5.2.2, para o aço rápido AISI M3:2 foi utilizado o diagrama de transformação isotérmica (T.T.T.) (ver FIG. 5.19), devido à dificuldade em se encontrar o diagrama C.C.T. para este material, além do mais, tal consideração pode ser feita (Totten, 2006). 


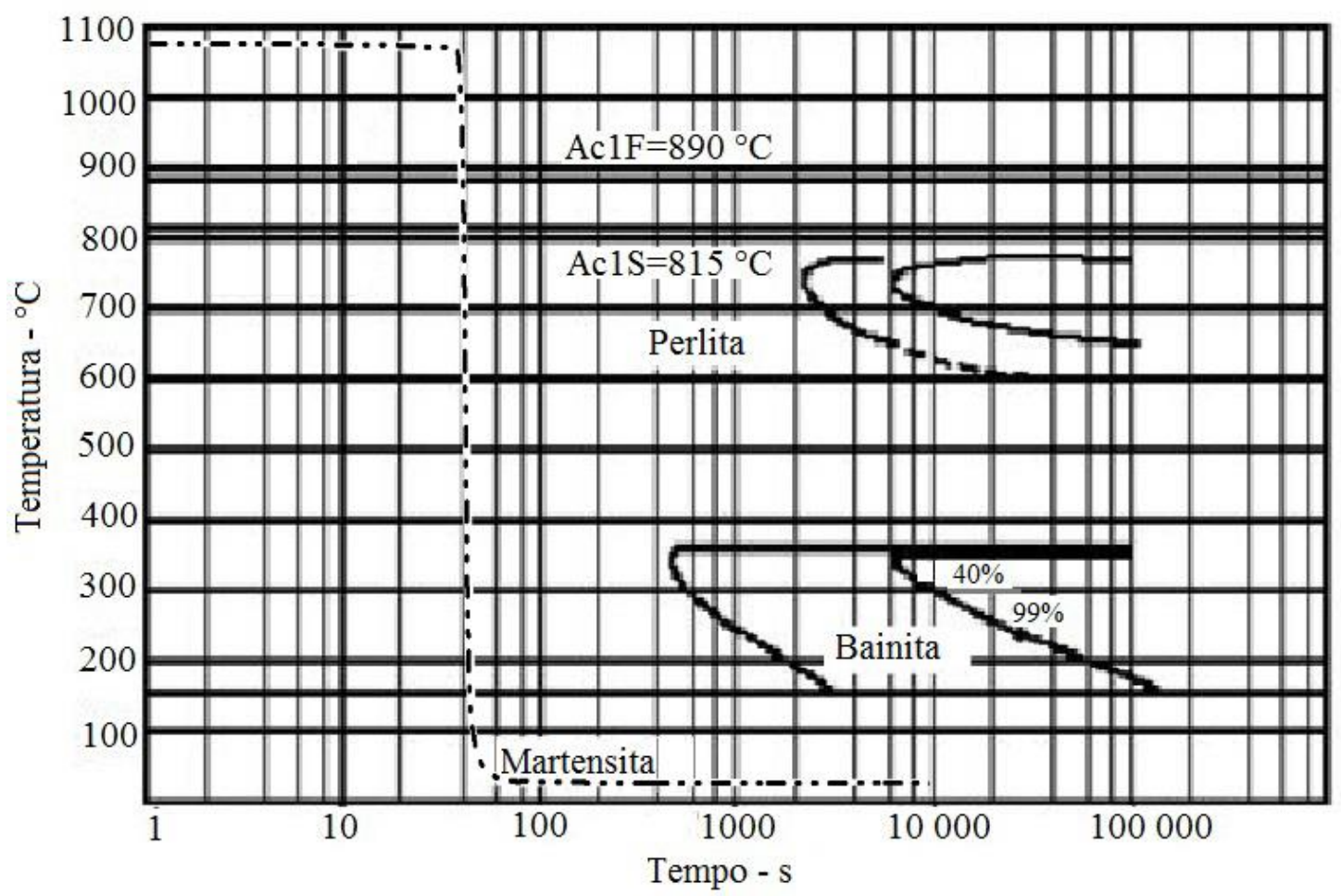

FIGURA 5.19 - Diagrama de transformação isotérmica (T.T.T.) para o aço rápido AISI M3:2 (Metal Ravne, 2016).

Os diagramas que melhor representam os tratamentos térmicos de têmperas são os diagramas de transformações sob resfriamento contínuo (C.C.T.). Estes por sua vez foram encontrados para o aço rápido AISI M2 (FIG. 5.20) e aço ferramenta AISI D2 (FIG. 5.21) (Vander Voort, 1991).

Os diagramas C.C.T. desenvolvidos por Vander Voort (1991) possuem sua forma de representação da linha de transformação de uma maneira não usual, conforme explicado no item 5.2.2. A linha de resfriamento vertical a ser plotada no diagrama deve considerar o tempo de resfriamento em minutos do material entre $800^{\circ} \mathrm{C}$ e $500{ }^{\circ} \mathrm{C}$. Porém, o tempo de resfriamento medido foi de 0,01 min para o VSI temperado ao óleo entre tal faixa de temperatura, portanto, a linha de resfriamento fica deslocada a esquerda do gráfico, pois este possui 0,1 min como menor medida. 


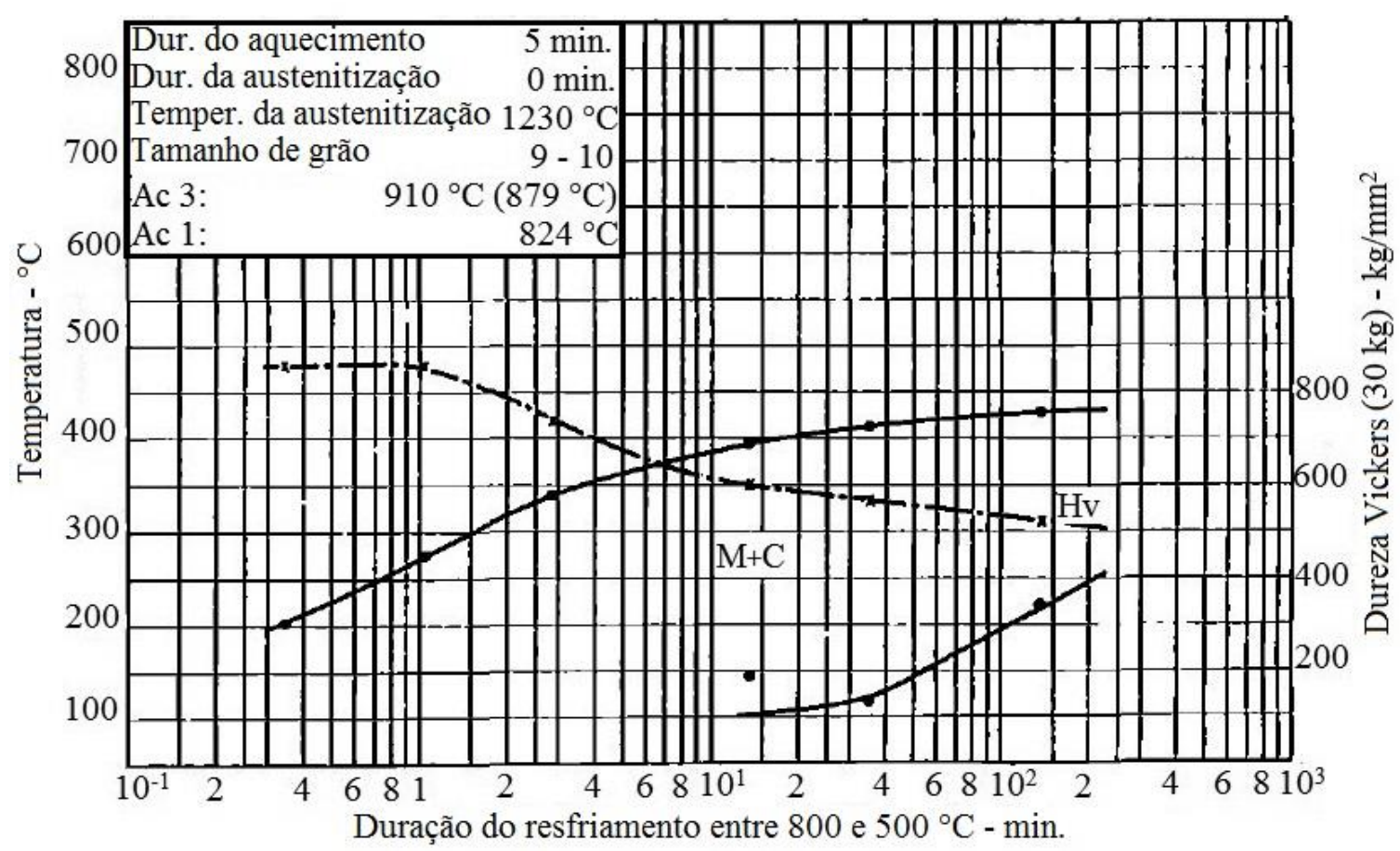

FIGURA 5.20 - Diagrama de transformação sob resfriamento contínuo (C.C.T.) para o aço rápido AISI M2 (Vander Voort, 1991).

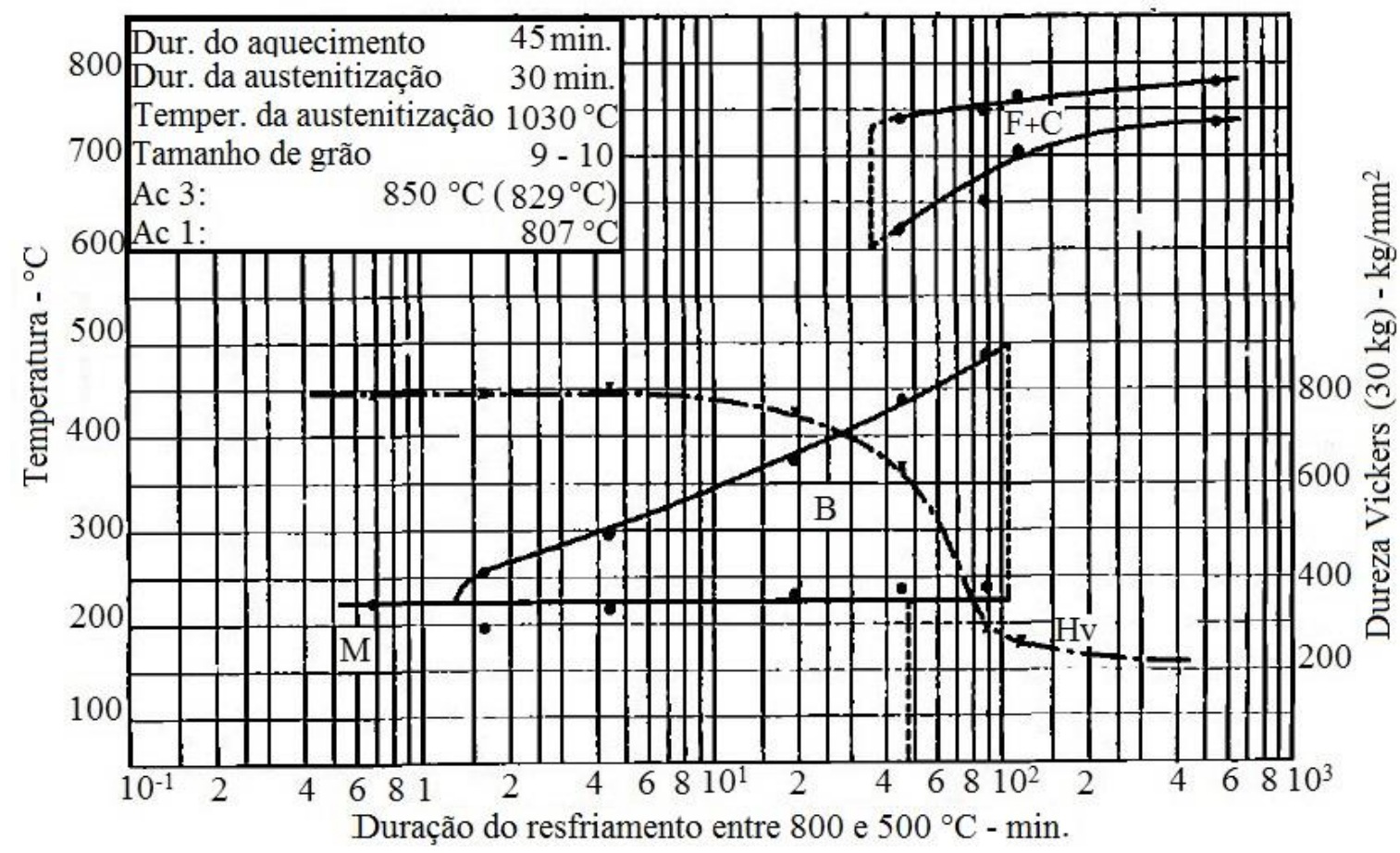

FIGURA 5.21 - Diagrama de transformação sob resfriamento contínuo (C.C.T.) para o aço rápido AISI D2 (Vander Voort, 1991).

Das curvas de resfriamento sobrepostas sobre os diagramas T.T.T. e C.C.T., mostrados anteriormente, pode-se inferir que a transformação da austenita 
do aço rápido AISI M3:2, aço rápido AISI M2 e aço ferramenta AISI D2 durante a têmpera ao óleo resultou somente na formação da martensita.

Além do mais, em cada mistura de pó encontraram-se microestruturas diferentes das previstas nos referidos diagramas. Isto pode ser devido ao fato da adição de outros elementos aos VSI, tais como os pós de ferro, sulfeto de manganês, carboneto de nióbio, grafite, entre outros, além dos pós de aços rápidos e aço ferramenta propriamente dito.

\subsubsection{Caracterização microestrutural}

A FIG. 5.22 mostra a seção transversal do VSI obtido com a Mistura 1 após tempera em óleo e revenido duplo a $400{ }^{\circ} \mathrm{C}$. É possível observar a distribuição do cobre $(\mathrm{Cu})$ nos contornos dos grãos com formato alongado. Há indícios da formação de grandes quantidades de perlita $(P)$, pois o ataque com Nital tende a penetrar nas lamelas desta fase, deixando-a escura quanto a sua aparência. Isto pode estar atrelado à partícula de ferro possuir o maior diâmetro médio e D50, ocupando maior espaço na microestrutura e também pode estar associado com a área em questão.

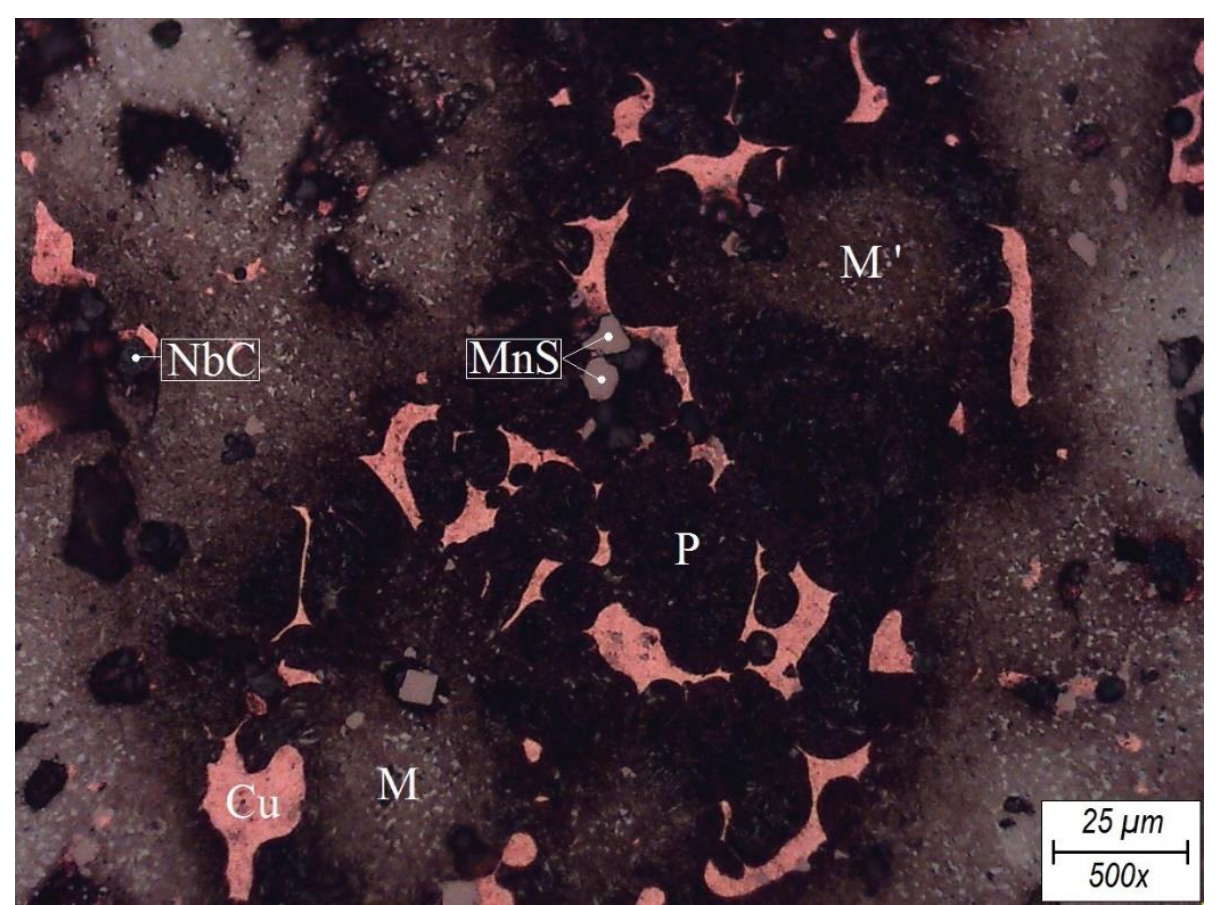

FIGURA 5.22 - Micrografia óptica da seção transversal do VSI obtido com a Mistura 1 (AISI M3:2) temperado ao óleo e duplamente revenido a $400{ }^{\circ} \mathrm{C}$. Ataque: Nital $3 \%$ por $5 \mathrm{~s}$. 
Já na FIG. 5.23 (seção longitudinal) da Mistura 1, o cobre apresenta-se com o formato mais arredondado. A mudança da morfologia das partículas de cobre na microestrutura do VSI está atrelada ao formato dos poros residuais do material, pois o cobre como elemento infiltrante apenas preenche os poros abertos do componente. Também, pode-se notar a menor formação de regiões perlíticas, pois na região analisada há o predomínio das partículas do aço rápido AISI M3:2.

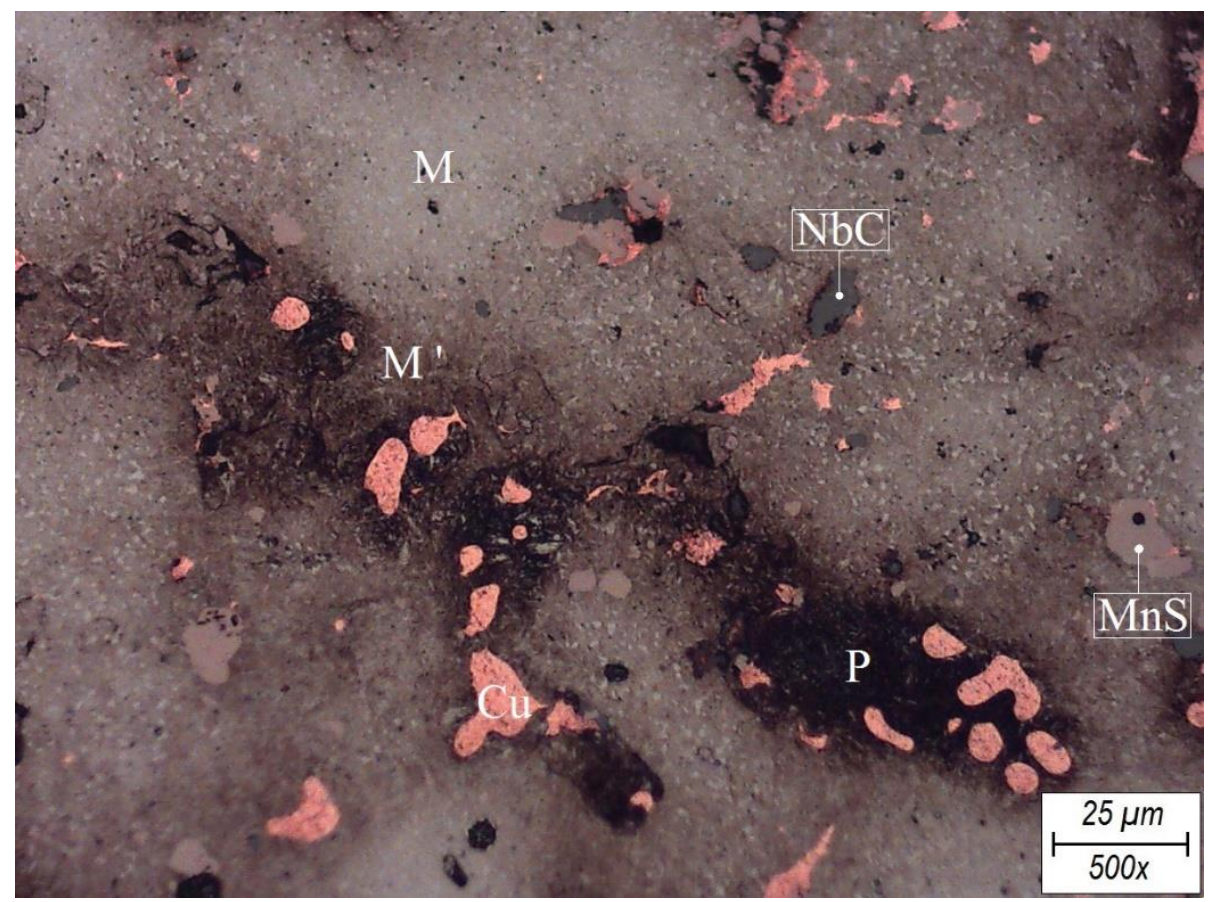

FIGURA 5.23 - Micrografia óptica da seção longitudinal do VSI obtido com a Mistura 1 (AISI M3:2) temperado ao óleo e duplamente revenido a $400^{\circ} \mathrm{C}$. Ataque: Nital $3 \%$ por $5 \mathrm{~s}$.

Na FIG. 5.24 (seção transversal) da Mistura 2 observa-se a presença de grandes quantidades de cobre distribuídas ao longo dos contornos de grãos. É possível distinguir entre as regiões bainíticas $(B)$, perlíticas $(P)$, martensíticas $(M)$ e martensíticas contendo altas concentrações de carbono $\left(\mathrm{M}^{*}\right)$. Também há presença de pequenas regiões ferríticas $(\mathrm{Fe})$.

A FIG. 5.25 (seção longitudinal) mostra a clara diferença que há entre as partículas do pó de ferro e do aço rápido AISI M2, que possuem formato esférico. Há uma grande quantidade de perlita que envolve a partícula do aço rápido, podendo estar relacionada à região específica de análise. É interessante notar que as partículas de sulfeto de manganês ( $\mathrm{MnS})$ e carboneto de nióbio $(\mathrm{NbC})$ estão presentes quase que em sua totalidade, dentro da fase de cobre. Isto pode ser 
relacionado à porosidade que havia envolta de tais partículas, sendo que os poros foram preenchidos posteriormente pelo cobre durante a infiltração metálica.

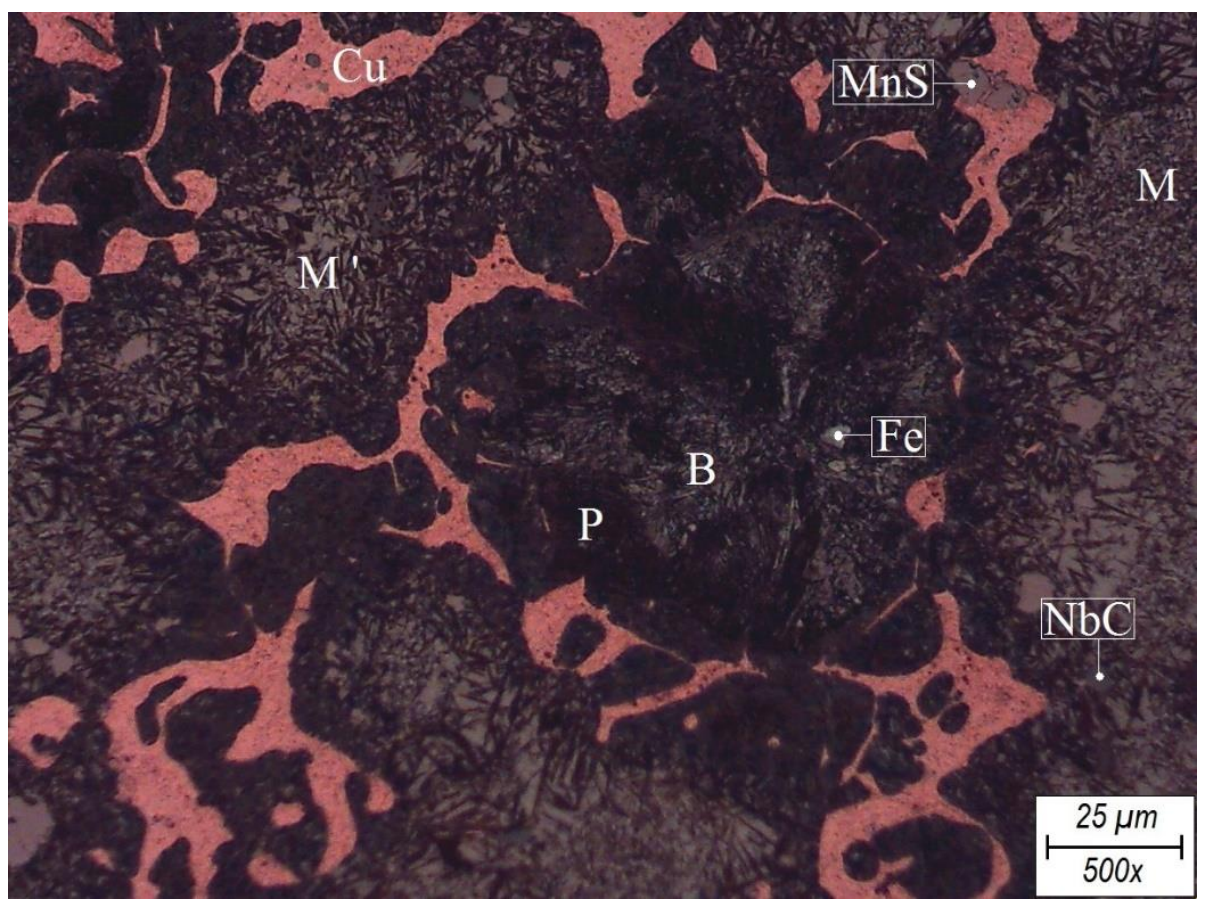

FIGURA 5.24 - Micrografia óptica da seção transversal do VSI obtido com a Mistura 2 (AISI M2) temperado ao óleo e duplamente revenido a $300{ }^{\circ} \mathrm{C}$. Ataque: Nital $3 \%$ por $5 \mathrm{~s}$.

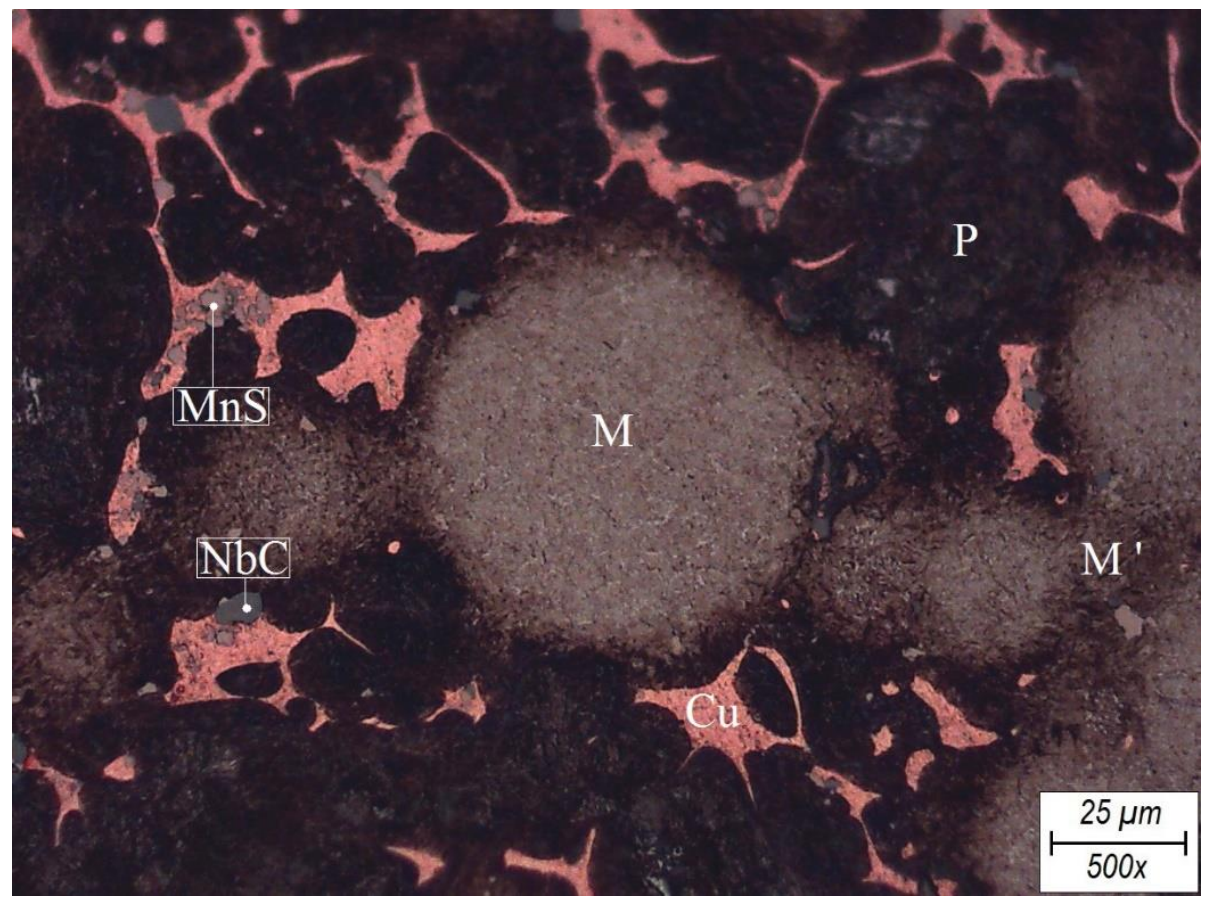

FIGURA 5.25 - Micrografia óptica da seção longitudinal do VSI obtido com a Mistura 2 (AISI M2) temperado ao óleo e duplamente revenido a $300{ }^{\circ} \mathrm{C}$. Ataque: Nital $3 \%$ por $5 \mathrm{~s}$. 
A FIG. 5.26 (seção transversal) da Mistura 3 (AISI D2) mostra a homogênea microestrutura resultante do tratamento térmico. O que se destaca é a fina distribuição do cobre e a relativa grande quantidade de ferrita distribuída sobre toda a microestrutura. Já para a FIG. 5.2 (seção longitudinal) se observa de diferente a distribuição de cobre mais grosseiro e menor presença da ferrita.

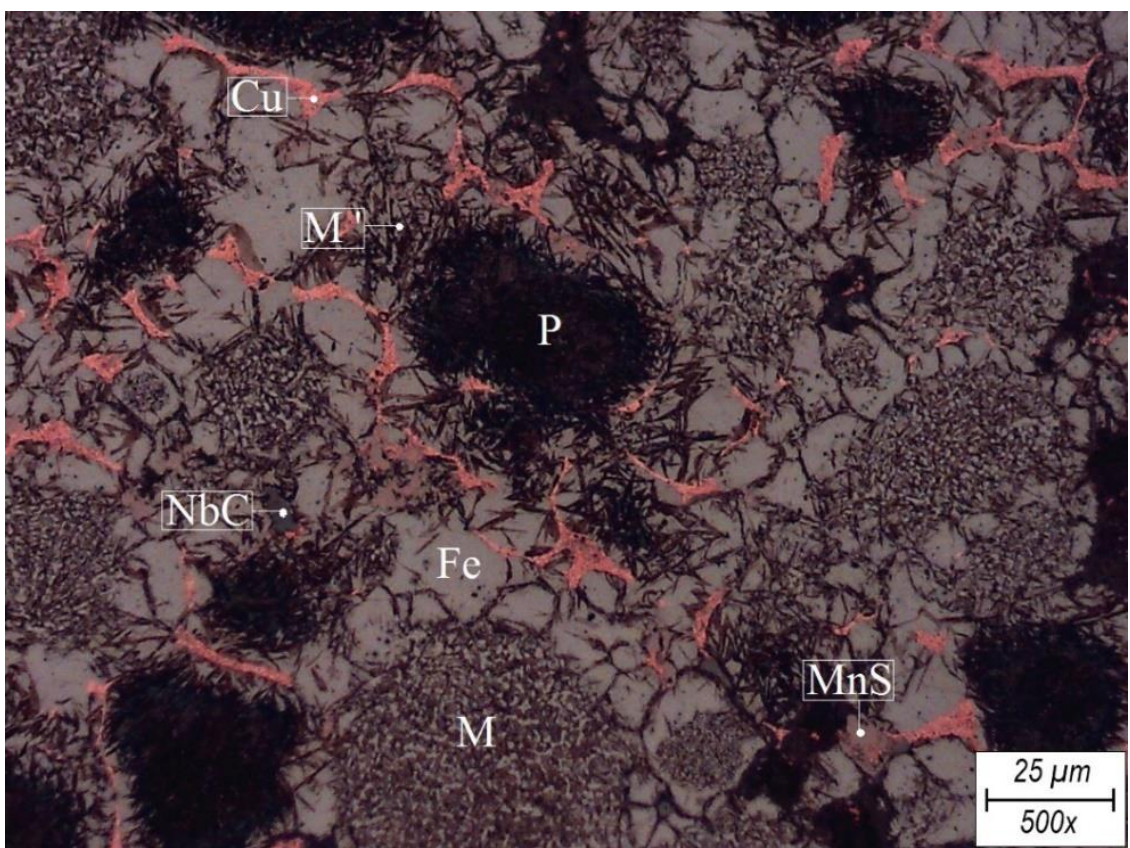

FIGURA 5.26 - Micrografia óptica da seção transversal do VSI obtido com a Mistura 3 (AISI D2) temperado ao óleo e duplamente revenido a $300{ }^{\circ} \mathrm{C}$. Ataque: Nital $3 \%$ por $5 \mathrm{~s}$.

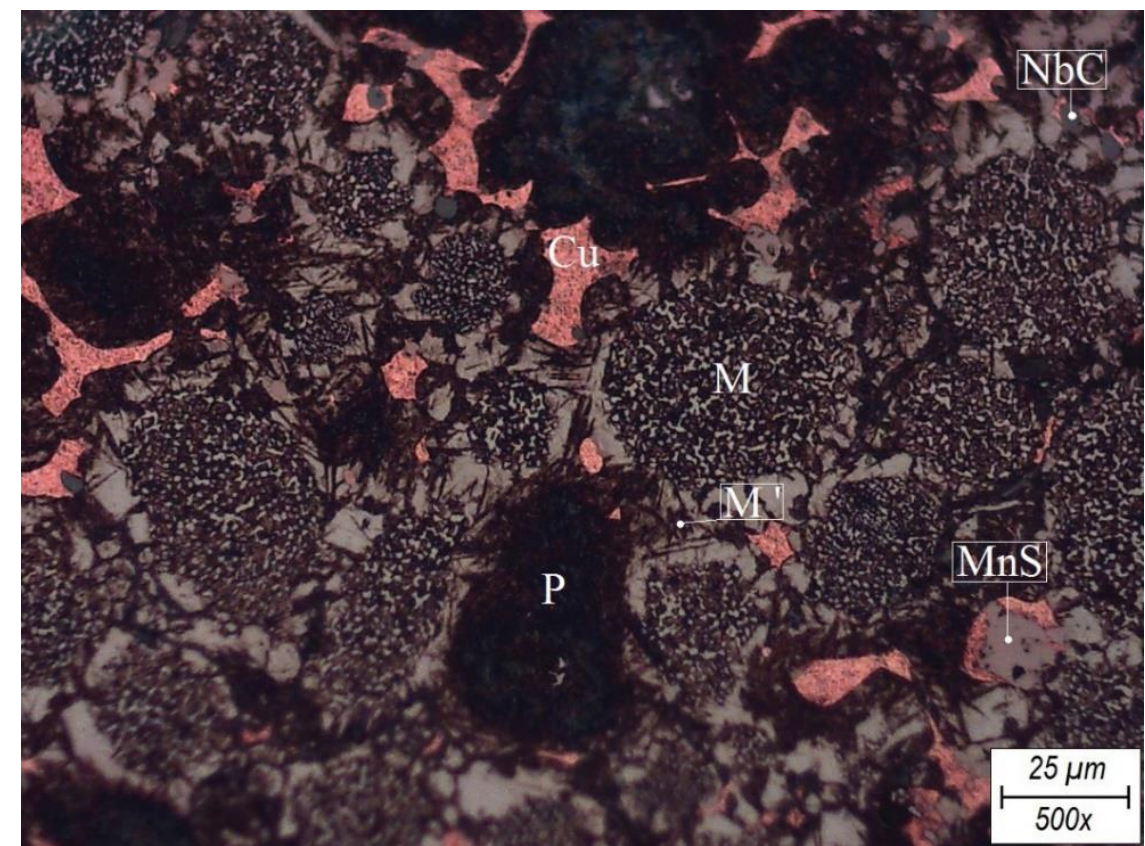

FIGURA 5.27 - Micrografia óptica da seção longitudinal do VSI obtido com a Mistura 3 (AISI D2) temperado ao óleo e duplamente revenido a $300{ }^{\circ} \mathrm{C}$. Ataque: Nital $3 \%$ por $5 \mathrm{~s}$. 
As fases presentes na Mistura 1 podem ser observadas por meio da FIG. 5.28 (seção transversal). Há a formação em pouca quantidade da fase perlítica (P). Já na FIG. 5.28 (seção longitudinal) ocorre o oposto e, esta variação nas quantidades da perlita deve estar relacionada à uma região específica de cada amostra. Nas duas figuras observa-se a boa distribuição do cobre $(\mathrm{Cu})$ em quantidades similares. Também pode-se observar a distribuição homogênea das fases perlíticas, martensíticas (M), martensíticas contendo altas concentrações de carbono $\left(\mathrm{M}^{\prime}\right)$ e de elementos, tais como o sulfeto de manganês $(\mathrm{MnS})$ e carboneto de nióbio $(\mathrm{NbC})$.

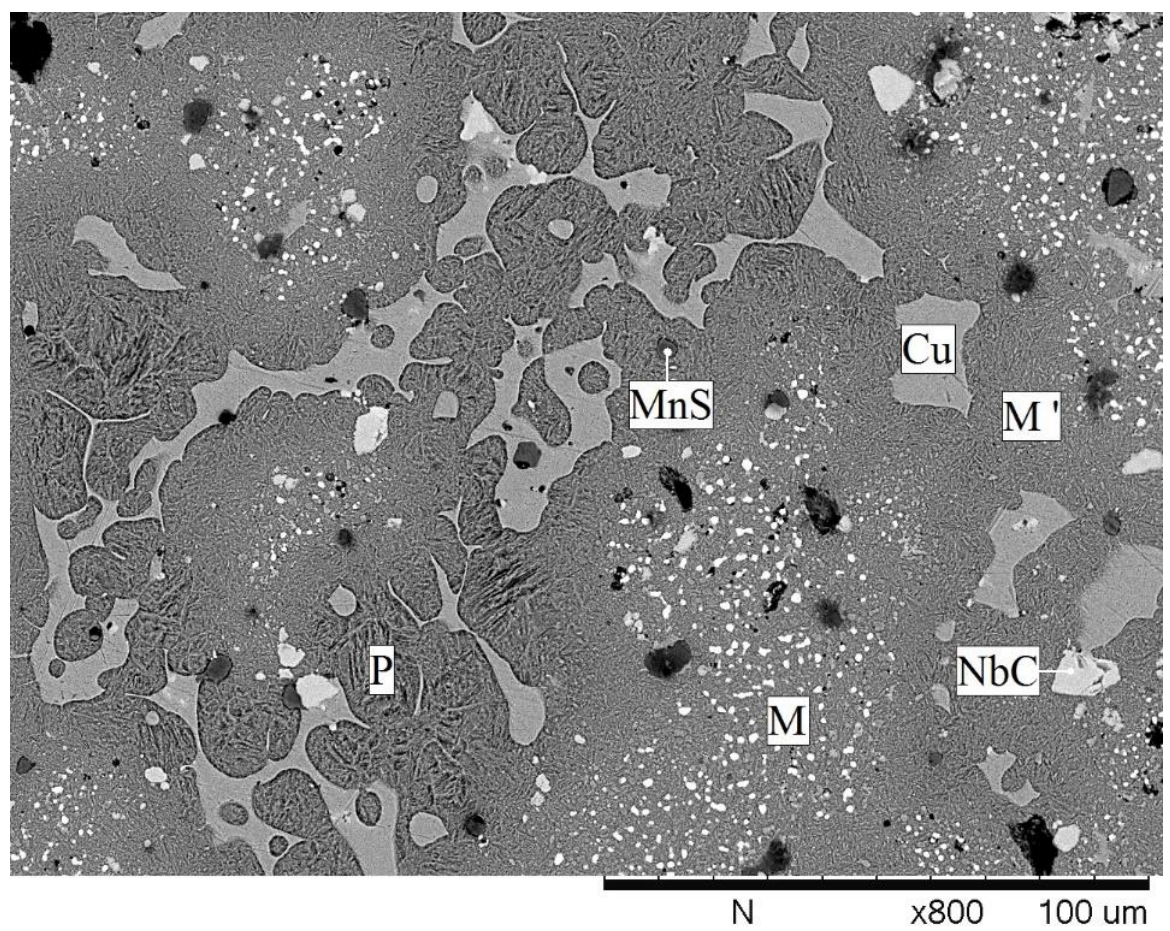

FIGURA 5.28 - Micrografia obtida por MEV com identificação de elementos por EDS da seção transversal do $\mathrm{VSI}$ obtido com a Mistura 1, após temperado ao óleo e duplamente revenido a $400{ }^{\circ} \mathrm{C}$. Ataque: Nital $3 \%$ por $50 \mathrm{~s}$. 


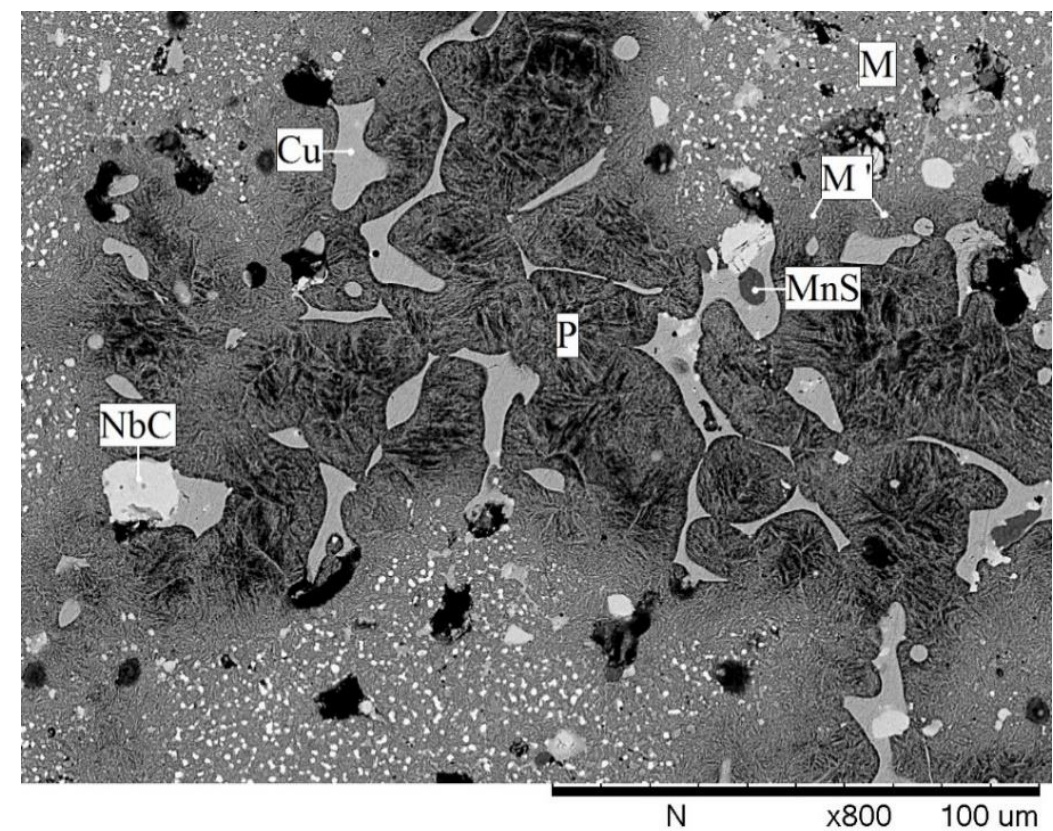

FIGURA 5.29 - Micrografia obtida por MEV com identificação de elementos por EDS da seção longitudinal do VSI obtido com a Mistura 1, após temperado ao óleo e duplamente revenido a $400{ }^{\circ} \mathrm{C}$. Ataque: Nital $3 \%$ por $50 \mathrm{~s}$.

É possível constatar o formato esférico das partículas do pó de aço rápido AISI M2 citado na TAB. 5.3 por meio das FIG. 5.30 (seção transversal) e FIG. 5.31 (longitudinal) para a Mistura 2. Em ambas as figuras nota-se a nítida diferença entre as diferentes fases presentes. E também, se observa na forma de pequenos pontos, os diferentes carbonetos do aço rápido em questão.

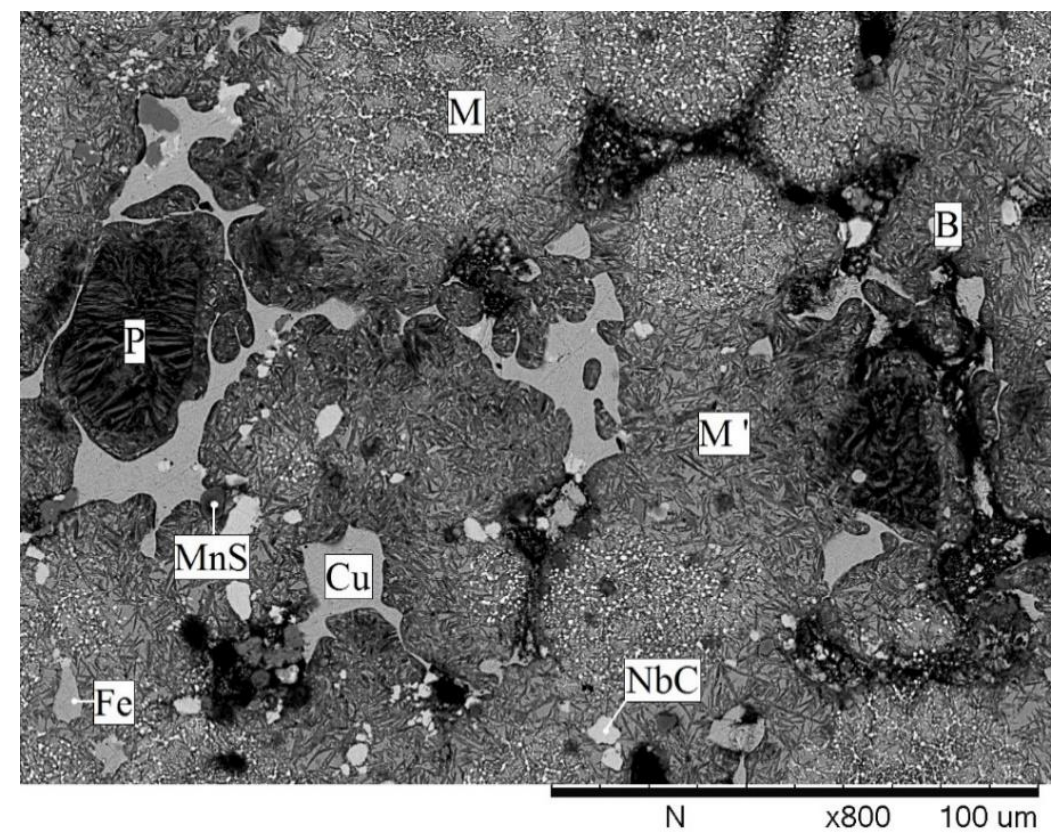

FIGURA 5.30 - Micrografia obtida por MEV com identificação de elementos por EDS da seção transversal do VSI obtido com a Mistura 2, após temperado ao óleo e duplamente revenido a $300{ }^{\circ} \mathrm{C}$. Ataque: Nital $3 \%$ por $50 \mathrm{~s}$. 


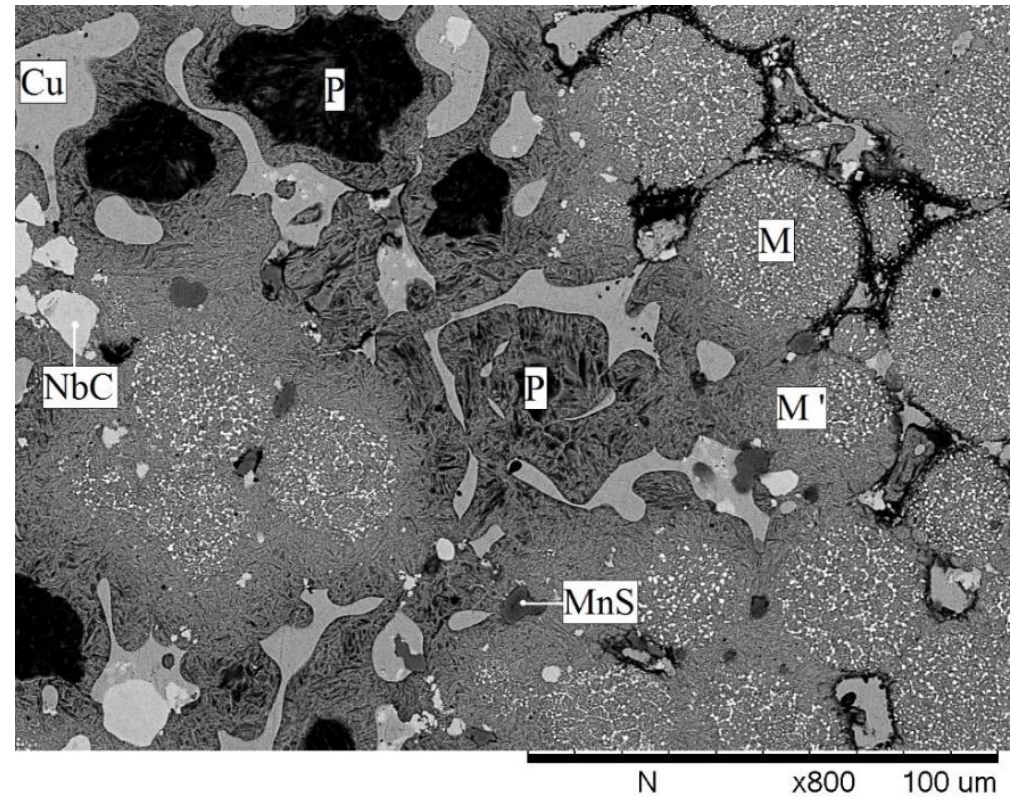

FIGURA 5.31 - Micrografia obtida por MEV com identificação de elementos por EDS da seção longitudinal do VSI obtido com a Mistura 2, após temperado ao óleo e duplamente revenido a $300{ }^{\circ} \mathrm{C}$. Ataque: Nital $3 \%$ por $50 \mathrm{~s}$.

As micrografias obtidas por MEV da Mistura 3 (AISI D2) são mostradas nas FIG. 5.32 (seção transversal) e FIG. 5.33 (seção longitudinal). Em ambos os casos, observa-se a pequena quantidade de cobre em comparação ao valor de referência de $11,79 \%$ apresentado na TAB. 5.2. É também evidenciada a presença de regiões escuras, que geralmente estão atreladas aos poros do componente.

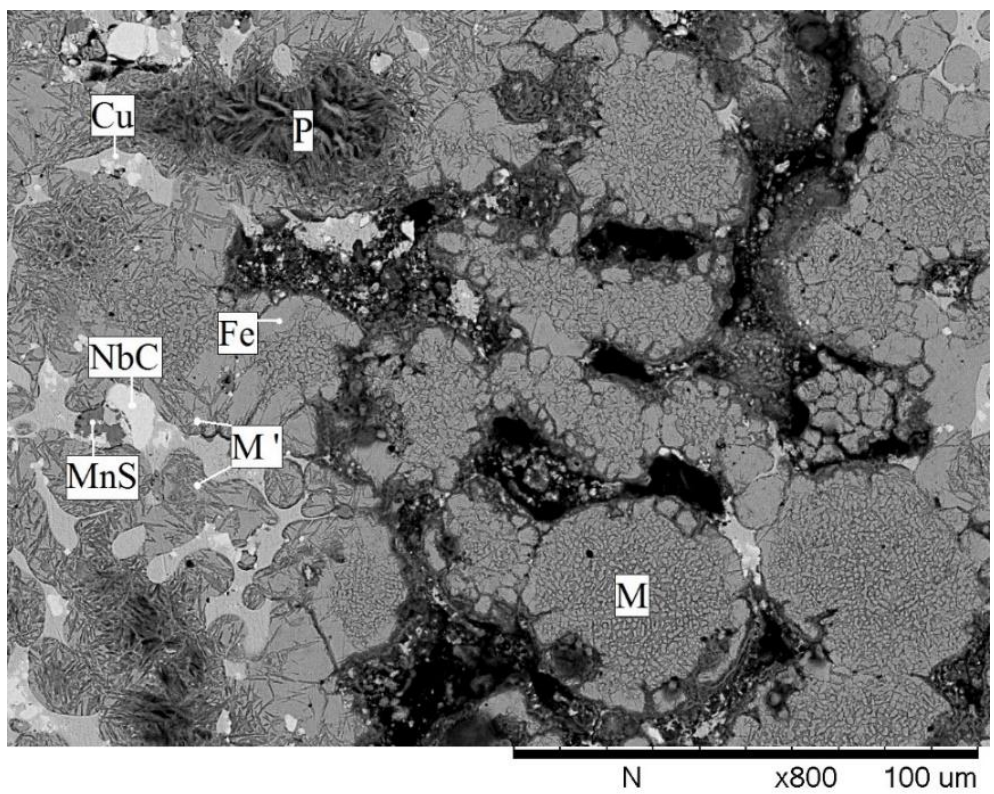

FIGURA 5.32 - Micrografia obtida por MEV com identificação de elementos por EDS da seção transversal do VSI obtido com a Mistura 3, após temperado ao óleo e duplamente revenido a $300{ }^{\circ} \mathrm{C}$. Ataque: Nital $3 \%$ por $50 \mathrm{~s}$. 


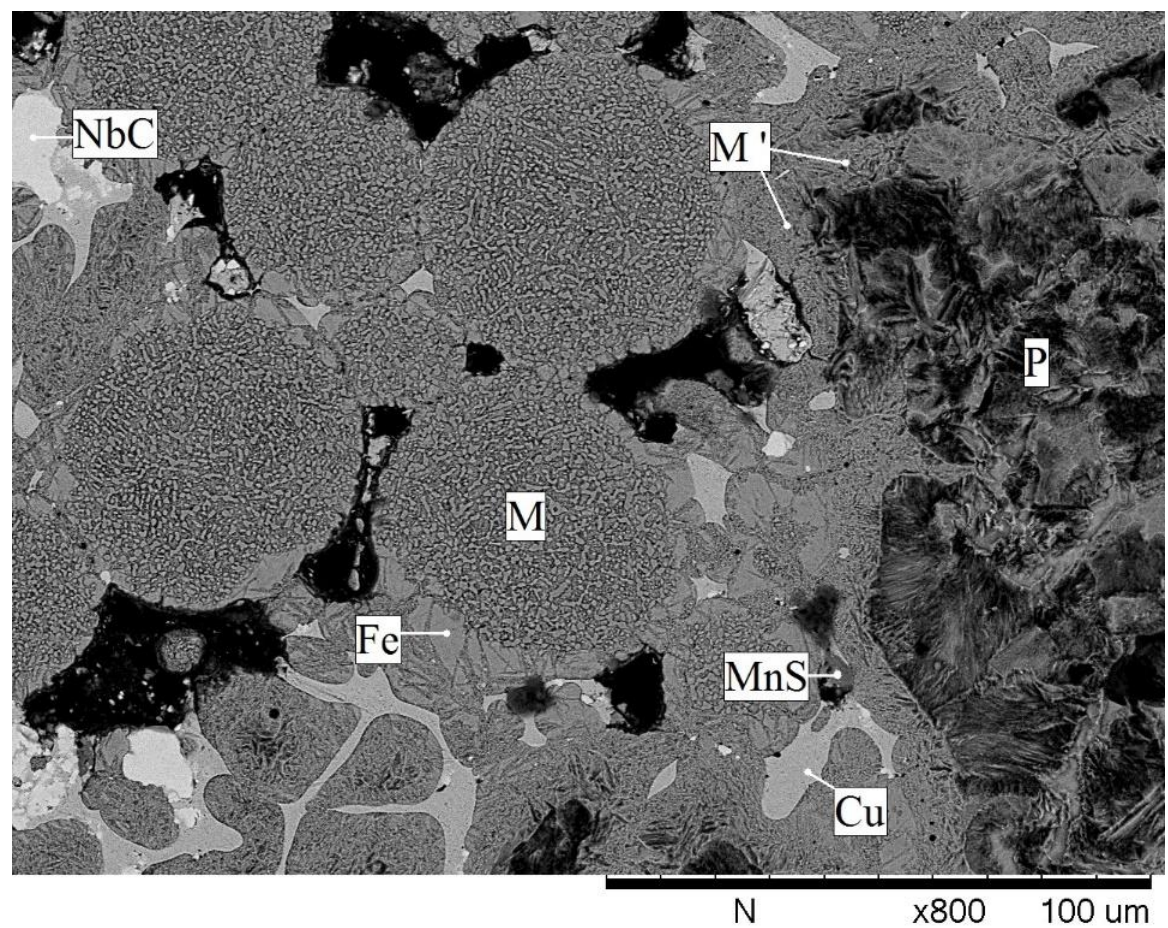

FIGURA 5.33 - Micrografia obtida por MEV com identificação de elementos por EDS da seção longitudinal do VSI obtido com a Mistura 3, após temperado ao óleo e duplamente revenido a $300{ }^{\circ} \mathrm{C}$. Ataque: Nital $3 \%$ por $50 \mathrm{~s}$. 


\section{CONCLUSÃO}

Dos tratamentos térmicos aplicados aos VSI, pode-se concluir que as evoluções das propriedades físicas e mecânicas no componente provaram ser eficientes, resultando em uma grande variação destas propriedades.

Embora existam muitas microestruturas e fases diferentes presentes no inserto de assento de válvula, as propriedades dos aços rápidos e aço ferramenta provaram ter a maior influência na resposta do material quanto às solicitações mecânicas e propriedades físicas de modo geral.

Para a têmpera ao ar, os componentes obtidos com a Mistura 1 (AISI M3:2) e Mistura 2 (AISI M2) são os mais consistentes no que tange sua dureza aparente, sendo esta uma das propriedades mais importantes ao inserto de assento de válvula.

Ainda se tratando da têmpera ao ar, apesar dos resultados inferiores dos componentes obtidos com o aço ferramenta AISI D2 (Mistura 3), sendo este um aço ferramenta para trabalho a frio, tais componentes atenderam as exigências mínimas impostas pelas montadoras.

No tratamento térmico de têmpera ao óleo houve a melhora significativa da resistência à ruptura radial dos componentes obtidos com a Mistura 2 (AISI M2) e Mistura 3 (AISI D2).

A têmpera ao óleo proporcionou resultados excepcionais aos VSI obtidos com a Mistura 3 (AISI D2), fato que foi evidenciado pelos elevados valores de dureza e resistência à ruptura radial obtidos após a aplicação de tal tratamento térmico.

Apesar do aço ferramenta AISI D2 (Mistura 3) ser um material para trabalho a frio, os ótimos valores de propriedades físicas e mecânicas resultantes dos diferentes tratamentos térmicos fazem deste um material de grande aplicabilidade na obtenção de insertos de assentos de válvulas, preservando-se as propriedades exigidas atualmente e, principalmente, a um menor custo de produção. 
Apesar do aço ferramenta AISI D2 (Mistura 3) possuir baixas propriedades mecânicas, o seu estudo é de grande interesse industrial devido ao seu menor custo em relação aos outros aços estudados. Este material custa três vezes menos do que o aço rápido AISI M2 e é aproximadamente quatro vezes mais barato do que o aço rápido AISI M3:2. 


\section{SUGESTÕES PARA TRABALHOS FUTUROS}

Realizar teste de desempenho em dinamômetro com os insertos de assentos de válvulas obtidos com as três misturas de pós, após estes terem sido tratados termicamente. Assim, é possível saber o comportamento dos componentes quando submetidos a condições reais de operação.

Aprofundar o conhecimento sobre a microestrutura resultante após os diferentes tratamentos térmicos aplicados, avaliando que tipos de carbonetos primários e secundários surgiram.

Avaliar a influência do tratamento térmico de sinterhardening nos componentes, pois este processo é realizado em conjunto com a etapa de sinterização, economizando-se tempo, custo e diminuindo a necessidade de operações posteriores. 


\section{REFERÊNCIAS BIBLIOGRÁFICAS}

ABNT NBR NM 136. Tratamentos Térmicos dos Aços - Terminologia e Definições. (Adotada no Brasil em outubro de 2000), São Paulo: ABNT, 1997.

ANDO, K.; MANABE, A.; YASUDA, A. Hardfaced valve and P/M valve seat system for CNG and LPG fuel engines. SAE Technical Paper 2005-01-0718, doi:10.4271/2005-01-0718, p. 1-10, 2005.

ANDRESS, D.; DAS, S.; JOSECK, F.; NGUYEN, T. D. Status of advanced lightduty transportation technologies in the US. Energy Policy, in press v. 41, p. 348364, 2012.

ASTM C 373-88. Standard Test Method for: Water Absorption, Bulk Density, Apparent Porosity and Apparent Specific Gravity of Fired Whiteware Products. ASTM International, 2004.

ASTM E 10-01. Standard Test Method for: Brinell Hardness of Metallic Materials. ASTM International, 2004.

BAYER, A. M.; BECHERER, B. A. ASM Metals Handbook Vol. 16: Machining. ASM Handbook Committee, 1989. High-speed Tool Steels, p. 51-59.

BURGOS, E. R.; CAMPOS, M. A. Automotive and regulatory trends in Brazil. SAE Technical Paper 2003-01-0568, doi: 10.4271/2003-01-0568, p. 1-12, 2003.

CHANG, I.; ZHAO, Y. Advances in Powder Metallurgy: Properties, Processing and Applications. United Kingdom: Woodhead Publishing, 2013.

CHIAVERINI, V. Aços e Ferros Fundidos. ABM, 1988.

CHIAVERINI, V. Metalurgia do Pó: Técnicas e Produtos. ABM, 1992.

COLPAERT, H. Metalografia dos Produtos Siderúrgicos Comuns. São Paulo: Edgard Blucher, 2008.

COMISSÃO NACIONAL DE ENERGIA NUCLEAR. J. L. Rossi; L. Salgado; F. Ambrozio Filho; E. S. Jesus Filho; J. C. Santos; M. A. Colosio. Inserto Sinterizado para Assento de Válvula e Processo para Fabricação do Mesmo. BR PI Pat. 0604220-1 A8, 14 set. 2006.

DALAL, K.; KRUEGER, G.; TODSEN, U.; HANNOVER, F. H.; NADKARNI, A. Dispersion strengthened copper valve seat inserts and guides in automotive engines. SAE Technical Paper 980327, doi:10.4271/980327, p. 1-9, 1998.

DEMATTÉ, E. Desenvolvimento e Avaliação das Propriedades de Insertos Sinterizados de Aço Rápido AISI M2 para Usinagem. 2006. Dissertação (Mestrado) - Universidade do Estado de Santa Catarina, Joinville.

DOWSON, G. Powder Metallurgy: the Process and its Products. USA: Adam Hilger, 1990.

FIGUEIRA FILHO, D. T. A. Dureza de Corpos Sinterizados. BS Indústria e Comércio de Produtos Metalúrgicos LTDA, 2016. 
FUJIKI, A.; KANO, M. New PM valve seat insert materials for high performance engine. SAE Technical Paper 920570, doi: 10.4271/920570, p. 24-28, 1992.

FUJITSUKA, H.; KAWATA, H.; OYANAGI, M.; MIYAZAWA, T.; FUJIKI, A. The development of a cobalt-free exhaust valve seat insert. SAE Technical Paper 2004-01-0502, doi: 10.4271/2004-01-0502, p. 1-9, 2004.

GERMAN, R. M. Powder Metallurgy and Particulate Materials Processing. USA: Metal Powder Industries Federation, 2005.

GERMAN, R. M. Powder Metallurgy of Iron and Steel. USA: Wiley-Interscience Publication, 1998.

GERMAN, R. M. Powder Metallurgy Science. USA: Metal Powder Industries Federation, 1994.

GERMAN, R. M. Sintering Theory and Practice. USA: Wiley-Interscience Publication, 1996.

GOMES, M. P.; SANTOS, I. P.; MUCSI, C. S.; COLOSIO, M. A.; ROSSI, J. L. Study of the mechanical and metallurgical properties of sintered steels for valve seat inserts application. In: VII Encontro Científico de Física Aplicada, Mai. 1113, 2016, Serra, ES, Brazil. p. 59-61.

GRUPO COMBUSTOL \& METALPÓ. São Paulo, SP, Brasil, 2014.

HAYASHI, K.; AOKI, Y. The development of sintered materials containing dispersed die steel hard particles for intake valve seat inserts. SAE Technical Paper 2001-01-0396, doi: 10.4271/2001-01-0396, p. 1-6, 2001.

HEKKERT, M.; HOED, R. V. D. Competing technologies and the struggle towards a new dominant design: the emergence of the Hybrid vehicle at the expense of the fuel cell vehicle. Greener Management International, v. 47, p. 29-43, 2004.

HÖGANÄS. Handbook for Sintered Components Vol. 6: Metallography. Höganäs AB; 2007.

HOWARD, I. ASM Metals Handbook Vol. 7: Powder Metal Technologies and Applications. ASM International, 1999. Cap. 1, Powder Metallurgy Methods and Design, p. 23-43.

HØYER, K. G. The history of alternative fuels in transportation: the case of electric and hybrid cars. Utilities Policy, v. 16, p. 63-71, 2008.

IERVOLINO, F.; BULLA, L. A Metalurgia do Pó: Alternativa Econômica com menor Impacto Ambiental. Grupo Setorial de Metalurgia do Pó, 2009. Cap. 7, compactação, p. 163-208.

JESUS FILHO, E. S. Processamento, Usinagem e Desgaste de Ligas Sinterizadas para Aplicações Automotivas. 2006. Tese (Doutorado) - Instituto de Pesquisas Energéticas e Nucleares, São Paulo.

KANO, M.; SUZUKI, K.; MATSUYAMA, H.; SATO, S.; YAMAGUCHI, M.; NINOMIYA, R.; NAKAHARA, Y. New copper Alloy powder for laser-clad valve seat used in aluminum cylinder heads. SAE Technical Paper 2000-01-0396, doi:

10.4271/2000-01-0396, p. 1-8, 2000. 
KAWATA, H.; HAYASHI, K.; ISHII, K.; MAKI, K.; EHIRA, A.; TORIUMI, M. The development of a high speed steel based sintered material for high performance exhaust valve seat inserts. SAE Technical Paper 980328, doi: 10.4271/980328, p. 1-9, 1998.

KAWATA, H.; MAKI, K. Development of high performance valve seat insert materials for heavy-duty engines. SAE Technical Paper 2006-01-0394, doi: 10.4271/2006-01-0394, p. 1-9, 2006.

KRAUSS, G. Steels: Heat Treatment and Processing Principles. USA: ASM International, 1990.

LEE, K. O. History of Knute Oscar Lee. Disponível em: <leblondusa.com/historyof-k-o-lee-part-one/>. Acesso em: 15 ago. 2017.

LOBERTO, A.; AMBROZIO FILHO, F.; SILVA, M. C. A. A Metalurgia do Pó: Alternativa Econômica com Menor Impacto Ambiental. Grupo Setorial de Metalurgia do Pó, 2009. Cap. 4, materiais, p. 103-126.

loberto, A.; GenOVA, L. A.; SILVA, M. C. A. A Metalurgia do Pó: Alternativa Econômica com Menor Impacto Ambiental. Grupo Setorial de Metalurgia do Pó, 2009. Cap. 8, sinterização, p. 209-230.

METAL RAVNE. Diagrama de transformação isotérmico (T.T.T.) do aço rápido AISI M3:2. Disponível em:

$<$ http://www.metalravne.com/steelselector/steels/ BRM3.html>. Acesso em: 15 jun. 2016.

MICHAEL, B. ASM Metals Reference Book: A Handbook of Data and Information. ASM International; 1981.

MIDLER, C.; BEAUME, R. Project-based learning patterns for dominant design renewal: the case of electric vehicle. International Journal of Project

Management, v. 28, p. 142-150, 2010.

MPIF Standard 35. Method for Determination of Crush Radial Strength. Metal Powder Industries Federation, 2009.

NOGUEIRA, R. M. U. Obtenção e Estudo de Insertos Sinterizados de Aços Rápidos AISI M2, M3/2 e T15. 2006. Dissertação (Mestrado) - Universidade do Estado de Santa Catarina, Joinville.

ORLANDIN, J.; CARVALHO, M.; MAZZA, P.; PEGORER, R. A Metalurgia do Pó: Alternativa Econômica com Menor Impacto Ambiental. Grupo Setorial de Metalurgia do Pó, 2009. Cap. 5, pós metálicos, p. 127-142.

ORLANDIN, J.; CARVALHO, M.; PEGORER, R. A Metalurgia do Pó: Alternativa Econômica com Menor Impacto Ambiental. Grupo Setorial de Metalurgia do Pó, 2009. Cap. 6, misturas, p. 143-162.

PALLINI, M. A. T.; BULLA, L.; LOBERTO, A.; LOPES, H. A Metalurgia do Pó: Alternativa Econômica com Menor Impacto Ambiental. Grupo Setorial de Metalurgia do Pó, 2009. Cap. 9, operações posteriores, p. 231-256.

PINHEIRO, J. I. D.; CUNHA, S. B.; CARVAJAL, S. R.; GOMES, G. C. Estatística Básica: A Arte de Trabalhar com Dados. Brasil: Elsevier Editora, 2009. 
SAKAI, M. Self lubrication type P/M materials for the lead free valve seat. SAE Technical Paper 2000-01-0395, doi: 10.4271/2000-01-0395, p. 1-7, 2000.

SALGADO, L.; AMBROZIO FILHO, F.; LEAL NETO, R.M.; ROSSI, J. L.; COLOSIO, M.A.; HERRMAN FILHO, C. R. P/M high-speed steels for valve seat insert application. SAE Technical Paper 2001-01-0395, doi: 10.4271/2001-010395, p. 261-264, 2001.

SANDVIK, B. P. J. The bainite reaction in Fe-Si-C alloys: the secondary stage. Metallurgical Transactions A, v. 13, p. 789-800, 1982.

SANTOS, I. P. Processamento e Caracterização de Aços Sinterizados para Uso em Insertos de Assentos de Válvulas. 2014. Dissertação (Mestrado) Instituto de Pesquisas Energéticas e Nucleares, São Paulo.

SATO, K.; MIDORIKAWA, T.; TAKAHASHI, T.; OSHIGE, H. Development of Valve Seat Material for Gas-Fueled Engines. SAE Technical Paper 2000-01-0911, doi: 10.4271/2000-01-0911, p. 1-10, 2000.

TANGZELIUS, J. A Metalurgia do Pó: Alternativa Econômica com Menor Impacto Ambiental. Grupo Setorial de Metalurgia do Pó, 2009. Cap. 2, impacto ambiental, p. 25-35.

TAYLOR, K. A.; CHANG, L.; OLSON, G. B.; SMITH, G. D. W.; COHEN, M.; SANDE, J. B. V. Spinodal decomposition during aging of Fe-Ni-C martensites. Metallurgical Transactions A, v. 20, p. 2717-2737, 1989.

THÜMMLER, F.; OBERACKER, R. An Introduction to Powder Metallurgy. Cambridge: The University Press, 1993.

TOTTEN, G. E. Steel Heat Treatment: Metallurgy and Technologies. USA: CRC Press, 2006.

TRUDEL, Y. ASM Metals Handbook Vol. 7: Powder Metal Technologies and Applications. ASM International, 1999. Powder characterization and testing, p. 8388.

VANDER VOORT, G. F. Atlas of Time-Temperature Diagrams for Iron and Steels. ASM International, 1991.

WHITE, D. G. ASM Metals Handbook Vol. 7: Powder Metal Technologies and Applications. ASM International, 1999. History of powder metallurgy, p. 10-23.

ZAPATA, C. W. Ciclo de Palestras Sobre Metalurgia do Pó. Faculdade de Engenharia de Joinville, 1987. 